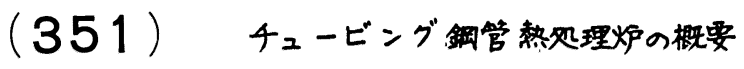

\title{
川崎䂏鉄知多製造所。田上俊入 丹羽春德奥村精
}

1 緒言；チュービング分野でのハイブレード品敝造のため、LPG燃烧の直烒㷫処理炉を建設し た。本炉の特徵は、アップセット部分をボディ部分の界熱速度にマッチングさせる、アップセット部急

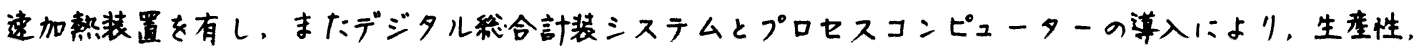
省エネルギー，品貝の各方面で大きく真献して いる。

$2 ア ッ フ ゚ セ ッ ト$ 部急速加㷫装置; 整処理炉 は、烧入炉と、绻もどし炉の2西から模成、れ て、る。烧入炉の急速加整装置を因11:示才。 炉内はバッフルにより，加㷫带，均熱带の2带 に区分、れ，急速加整装置は，加然带の全长， およで均㷛带の一部に設置されて、るる。炉内力゙ スは循渨ファン®により吸引、れ，炉天并に設 けられた追焚バーナーにより所定沮度まで加整

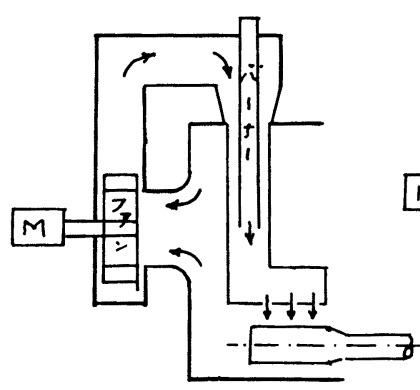

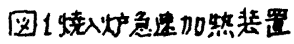

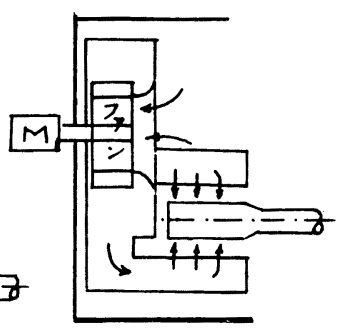

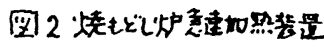
ホれた後，高速でアップセット部に吹、付けら れる。烧もどし妒の急速加整装显を因2に示す。900

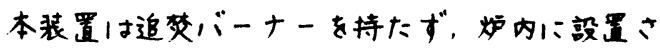
れた循環ファンによって、アップセット部に炉 内燃烧ガスが高速で吹き付けられる。設置され て、る場所は燎入炉と同栚だが，効事を增才た め、アップセット部の下部からも然風を吹、付

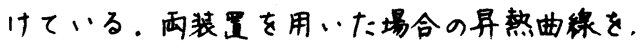
因3(烧入炉)，四4（焼もど(炉）、示才。 急速加鶖装置を用・た場合のアップセット部は， ボディ部より界整スピードが速くなっている。 3計装制御システム；本システムは以下の

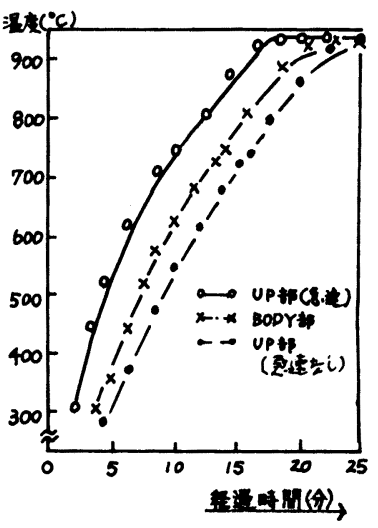

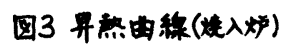

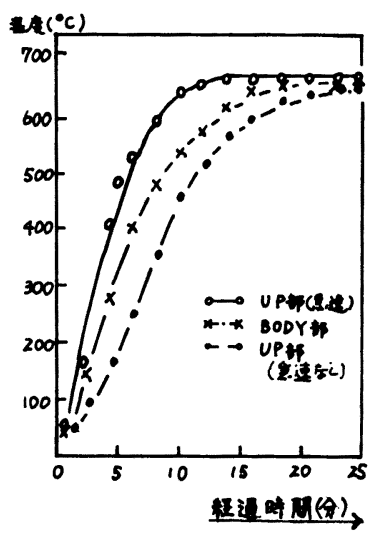

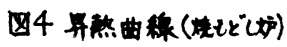

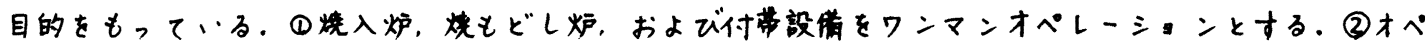

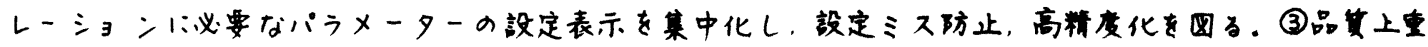
要な情報はパターン表示し，かつロット每のデーターをロギングする。焦効事の向上およでスケール

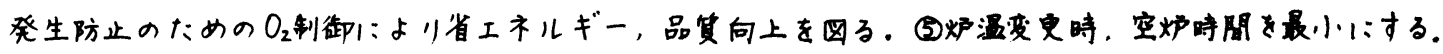

ミれらを実現するためにディジタル総合計装システムとプロセスコンピューターを革入した。高能围

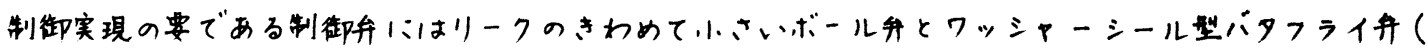

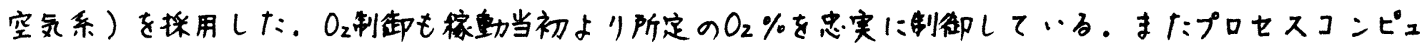
ーターは，ロット管理用ピーストラッキンブ，整処理合否判定，リニアプログラミングを用いだ次口 ット装入時間スケジューリンブ，炉内でのパイプ停止位是制御のための测长等を行なっている。 
1. 緒言 バッチ式焼鈍炉の燃料・電力原単位や操炉技術の向上のために，インナカバー内の雾囲気ガス偱環 を解明することは，非常に重要である。そのために実機の $1 / 3$ 縮尺の模型を使用して風量分布計算に必要な各種の抵抗係数を求 め，一般性のある風量分布算出モデルを作成した。これを基䃈に 作成した焼鈍灯伝熱シミュレーションモデルについてはすでに報 告した。ここでは, 模型実験によつて得られた結果について報告 する。

2. 実験方法 全偱環風量が正確に測定できるアクリル製の実機の $1 / 3$ 縮尺の模型を用いて, 流れの様子の観繁と風量分布の測定を 実施した。風量分布の測定は熱線風速計および差压式流量測定法 を併用した。差压式流量測定法とは，個々のスペーサを流れる流 量とスペーサ外周部と内周部間の差圧の関係を測定しておき，コ

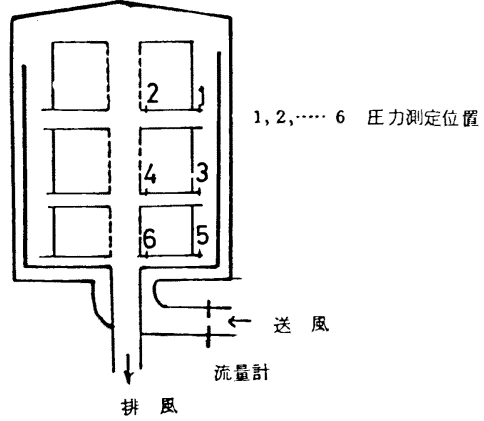

図1アクリ几製模型

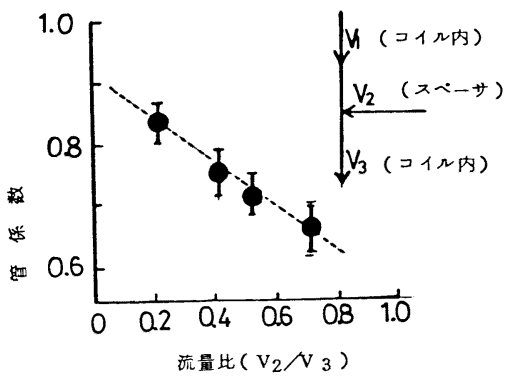

図 2 コイル内孔部での管俰数 れる流量比率の一例を図3 に示した。流量分布は各スペーサ のリブ高さによつて大きく変化するが，それを均一にするた めには，上段のスペーサリブ高さに比較して，下段のスペーサのリ ブ高さを小さくすればよい。汹 4 に示したように下段のスペーサは 上段に比較して，スペーサ部の差圧は大きくなり，流れやすくなる からである。また本実験により， 流量分布算出に必要な合流部, 分 岐部やスペーサ部の圧損係数を求 めた。

5 . 結言 バッチ焼鈍炉の偱環風量 分布の解明により, 一般性のある 風量分布算出モデルを作成した。 この結果，各段のコイル温度を均 一化するための知見を得ることが できた。

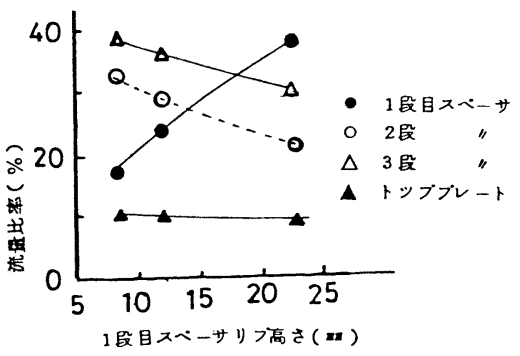

因3 3段峨での流量分在の列

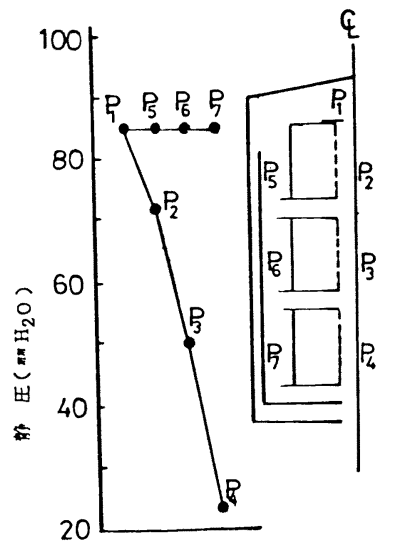

因4 インナカバー内の印力分布例

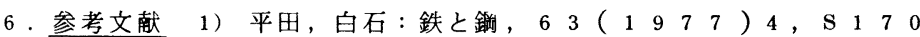


'80-S 954

(353)
621.785.3: 621.783.222: 65.012.22

バツチ式焼鈍炉の加熱完了予測

パツチ式焼鈍炉の最適操業方法（その2）

川猗製鉄秼) 水島製鉄所 $。$ 藤井慎吾 貝原利一 飯田祐弘

鮫島一郎 白石典久

1 . 緒言 燃量原単位の削滅, 並びに操炉技術の向上を目指し，シミュレーションモデルを用いてバッチ式焼 鈍炉の最適操業法（加熱完了予測）を確立したので報告する。

2 . 焼鈍㻏シミュレーションモデル

卮熱モデルでは，焼鈍少内のほとんどの熱的現象が考慮されてお り，燃焼ガス抢よびレトルト内の雾囲気ガスについて微小体積毎に 熱バランスをとり，コイルまわり境界条件を計算させることができ る。現在，このモデルの精度は図 1 に示すようにほほ士 5 足の範囲 に入る。(図1)

\section{3 . 加熱完了予測}

（1）概要 加熱完了予測はこの高精度なモデルを用い，従来判然と しなかつたコイル内の最冷点温度を正確に予測し, 全段コイル についてそれらすべてが治金的に必要とされる目標温度に到達 した時点でガス止めするという考えに基づいたものである。 (四 2 )

（2）加熱完了予測式一般に大容量の雾囲気中に固体を放置した場 合，その固体温度 $\mathrm{T}$ は対数曲線に従つて上昇する。そこで, (均熱温度一最冷点温度) を対数にとり，その上昇勾配をみ たのが図 3 である。したがつて加熱完了予測の基本式は次 のように表わされる。

$$
10 \mathrm{~g}\left(\mathrm{Ts}-\mathrm{Tc} . \mathrm{s} . \mathrm{V}^{-}\right)=\alpha+\beta \mathrm{t}
$$

（Ts：均熱温度, Te.s. : 目標最冷点温度, $\mathrm{t}$ ：予湘開始 時から目嫩温度に到達するまでの時間, $\alpha$ : 予測開始時の最 冷点温度, $\beta$ : 予測開始時の上昇勾配）

この $\alpha, \beta$ は各段コイル幅, 重量, 加熱能力等より統計的に 回㷌されるものである。

4. 装入コイル最適積付法

上記予測式を用い，逆に点火上り同一時間経過後に全段 コイルの最冷点温度が目標温度に到達する各段コイル幅 （最適コイル幅）を算出した。その一例を表 1 に示す。 これにより効率的な装入コイルの積付が可能となつた。

5 . 結言 焼鈍炉シミュレーションモデルを利用することに より，加熱完了予測，最適皘付のみならず，冷却完了尒 測，最適スペーサー配列等についてバッチ式焼鈍炉の最 適操業法を採用できるようになつた。

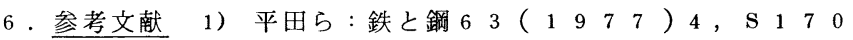
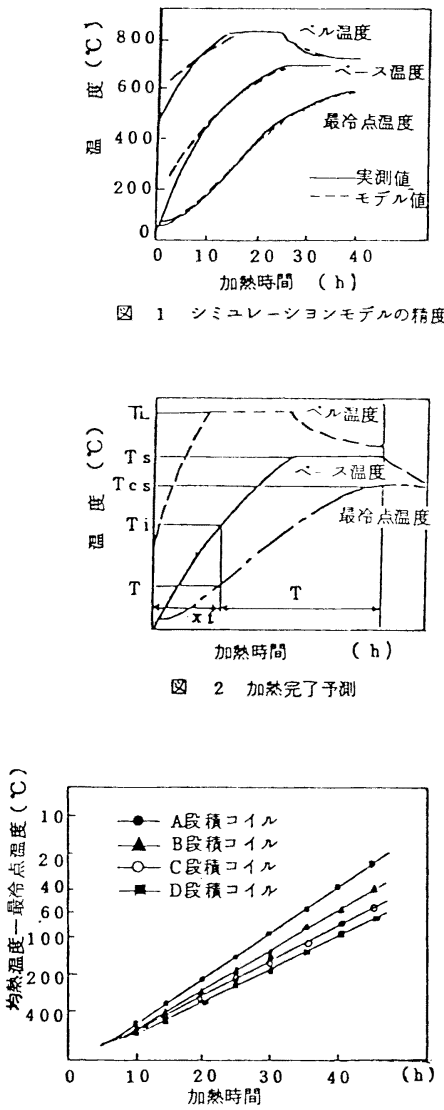

因 3 コイル内最冷点の上年勾配

表 1 最適コイ几幅（例）

\begin{tabular}{|c|c|c|c|c|c|}
\hline $\mathrm{A}$ 段幅( $(\boldsymbol{m})$ & B 段幅 $(\mathbf{m})$ & C段幅 $(\mathrm{n} \pi$ & 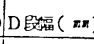 & 加赫時间)( & 于r一媑量(t) \\
\hline 1200.0 & 1047.5 & 811.5 & 942.4 & 33.05 & 150.2 \\
\hline 1225.0 & 1070.7 & 837.2 & 981.5 & 33.86 & 154.4 \\
\hline 1250.0 & 1093.9 & 862.9 & 1020.7 & 34.70 & 158.7 \\
\hline 1275.0 & 1117.2 & 888.7 & 1059.7 & 35.57 & 162.9 \\
\hline
\end{tabular}




\section{高温鋼板のラミナー冷却一第 2 報一}

（回転高温鋼板における単一流による冷却）

(侏) 神戸製鋼所 中央研究所 $\bigcirc$ 大友朗紀 (工博)山口喜弘中尾正和 水田篤男大砂 寬 柚垣英則

1 緒 言: 第 1 報の静止した高温鋼板を用いた実験に続き、 本報においては、回転高温鋼板を用いた実験から諸因子がブラッ クゾーン形成へ及ぼす影響について調査したので報告する。

2 実験方法： ステンレス鋼板 $\left(3 \mathrm{~mm}^{\mathrm{t}}\right)$ を所定温度に加熱し、 半径 $0.56 \mathrm{~m}$ で回転させ、上面から単一ラミナー流による冷却を行 ない、試験片裏面によどみ点を中心として $10 \mathrm{~mm}$ 間隔に溶接した $0.3 \mathrm{C}$-A 熱電対により記録した。実験範囲を表 1 に示す。

表 1 実験条件

\begin{tabular}{|c|c|c|}
\hline 鋼板温度 & $\mathrm{T}$ & $400 \sim 900\left({ }^{\circ} \mathrm{C}\right)$ \\
\hline 鋼板 速 度 & $\mathrm{V}$ & $1.5 \sim 12.0(\mathrm{~m} / \mathrm{s})$ \\
\hline ノズル高さ & $\mathrm{H}$ & $390 \sim 1510(\mathrm{~mm})$ \\
\hline 水 量 & $\mathrm{W}$ & $5 \sim 30(\ell / \mathrm{min})$ \\
\hline 水 温 & $\mathrm{T}_{W}$ & $5 \sim 50\left({ }^{\circ} \mathrm{C}\right)$ \\
\hline
\end{tabular}

\section{3 实結果及ひ検討}

3.1 諸因子の変化と冷却状態: 諸因子の冷却 状態への影響を図 1 に示す。（1）W，H及びサ ブクール度 $\Delta \mathrm{Tsub}$ 増加は主にブラックゾーン 領域を払大し、(2) $\mathrm{V} ， \mathrm{~T} の$ 低下は主にブラッ クゾーン内のよどみ点近傍での冷却能力を増大 することに影響を与えていると考えられる。 3.2 諸因子と平均温度降下率: 本報にては、 よどみ点を中心とする幅 $60 \mathrm{~mm}$ における水冷却 による平均温度降下を空冷をも含んだ時間で割 った平均温度降下率にて評価した。図2 (a)にノズ ル高さの影響の例を示す。ノズル高さが増加す るにつれて、冷却能力は増大するが、1 $190 \mathrm{~mm}$ を越えるとかえつて減少する所がある。これは ノズル高さが高くなると衝突時に飛散が起こり、 水が有効利用されないためである。ま た、困2(b)に鋼板速度の例を示す。 $\mathrm{v}$ の 効果は図 1 にも示したように低速側で よどみ点近傍の冷却能力が増加してい ることが影響している。以上、実験範 囲にて、諸因子の平均温度降下率 $\mathrm{Q}$ と の関係は(1)式で示される。

$$
\begin{gathered}
\mathrm{Q} \propto \mathrm{w}^{(0.70 \sim 0.85)} \cdot \mathrm{V}^{(-0.35 \sim 0.45)} \\
\cdot \mathrm{f}(\mathrm{T}) \cdot \Delta \mathrm{Tsub}{ }^{1.35}-(1) \\
\text { ここで、 } \mathrm{f}(\mathrm{T}) \text { は } 400 \leqq \mathrm{~T} \leqq 550(\mathrm{C}) \\
\text { で } \mathrm{T}^{-1.8}, 550 \leqq \mathrm{~T} \leqq 900(\mathrm{C}) \text { で ex p } \\
\{-5.3 \times 10 \quad \text { T }\} \text { に比例する。 }
\end{gathered}
$$

1) 鉄と鋼'78-S 707

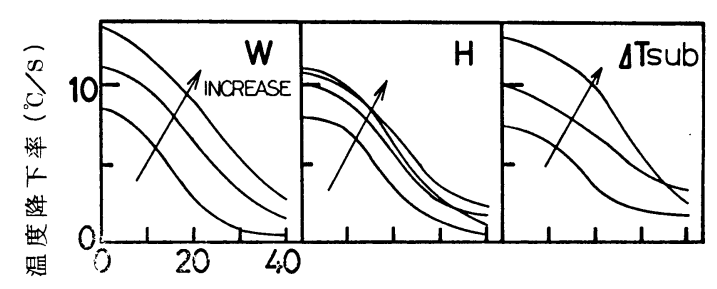

よどみ点からの距離 $(\mathrm{mm})$

図 1 冷却状態

$(\mathrm{V}=5.2 \mathrm{~m} / \mathrm{s}$, $\mathrm{H}=550 \mathrm{~mm}$, $\mathrm{T}=850^{\circ} \mathrm{C}$, $\mathrm{T}_{\mathrm{W}}=26{ }^{\circ} \mathrm{C}$, $\mathrm{W}=15 \ell / \mathrm{min})$

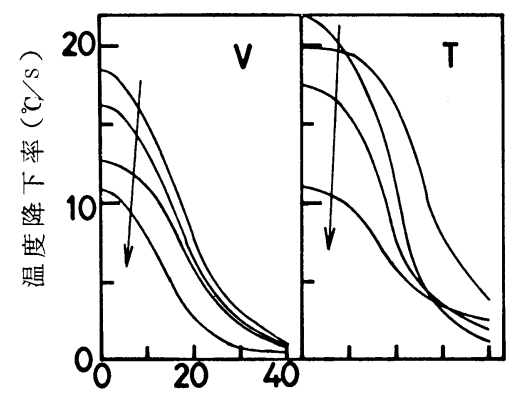

よどみ点からの距離 (mm)

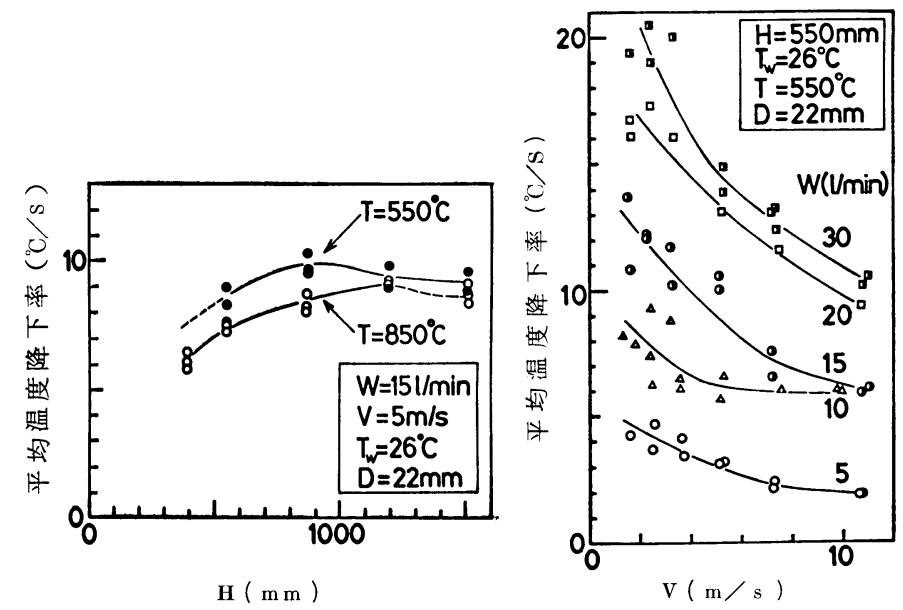

図 2 (a)ノズル高さの影響

図 2 (b) 銅板速度の影響 


\section{（355）鋼板の 2 次スケール剥離に及ぼす水噴流条件の影響}

(神戸製鋼所 中央研究所 ○中尾正和（工博）高塚公郎 村上昌平 安永繁信 (工博) 山口喜弘

1 粕 言： 熱間圧延ラインで生成する 2 次スケールのデスケーリングとして、一般に $100 \sim 150$ $\mathrm{kg} / \mathrm{cm}^{2}$ の高圧水によるスプレイ噴射が用いられているが、このような高圧水の使用がスケールの剝離に 如何ほど効果的であるかは明らかでない。特に昨今のエネルギー事情から省電力を考慮した効率的なデ スケーリング方法が要請されている。スケールの剥離性に関する研究は過去に数例みられるが、ここで はホットストリップ仕上圧延前の 2 次スケールを想定し、実験室的に生成したスケールの剥離に及ぼす スプレイ条件の影響について調べた結果を報告する。

2 実験方法：供試材の寸法は $80 \times 100 \times 30 \mathrm{~mm}$ で、熱延ラフバー クロップより切り出した。実験装置の概略を図 1 に示す。A r ガス 雲囲気で加熱した試験片を加熱炉から抽出後、回転テーブル上で所 定時間の空冷によりスケールを生成させた後、スプレイ噴射による デスケーリングを行なった。なお加熱中の試験片の酸化は表面に合 せ板をのせることにより防いだ。加熱温度は $1100 \sim 1200^{\circ} \mathrm{C}$ 、空冷時 間は 45 秒、水冷開始温度は $1000 \sim 1100^{\circ} \mathrm{C}$ 、鋼板の移動速度は 1.4

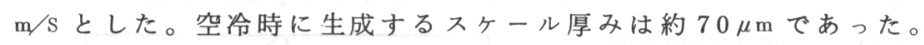
スプレイ用ノズルは流量の異なる 4 種類のフラット型を用いた。 スケールの剥離状態はスプレイ噴射直後の写真撮影から、スケール 残存量の目視評価を行なった。

\section{3 実験結果}

(1) スプレイ噴射前後のスケール状態の観察結果の 1 例を写真 1 に 示す。スケール被膜には空冷後 $10 \sim 20$ 秒でブリスターの発生が見 られた。

(2) 1 回転目の水噴射によるスケールの剝離状態は図 2 に示すよう にスプレイの噴射圧と流量によって異なる。眓からスケールを完全 に剝離させるに必要な最小の噴射圧 $\mathrm{P}_{0}$ と流量Q。

$$
\mathrm{P}_{\mathrm{o}}^{0.4 \sim 0.5} \times \mathrm{Q}_{\mathrm{o}}=\text { const }
$$

噴射面積がほぼ一定の実験条件から、このような関係は剝離限界が 噴流による衝突圧に依存していることを示唆している。流量分布、 噴射圧の測定から推定した完全剥離に必要な衝突圧は $0.12 \sim 0.16$ $\mathrm{kg} / \mathrm{cm}^{2}$ であった。

(3) スプレイ噴射開始温度として $1000{ }^{\circ} \mathrm{C}$ と $1100^{\circ} \mathrm{C}$ を比べると完全 剥離領域は $1000^{\circ} \mathrm{C}$ 方がやや低圧側になるが大差はない。

参考文献

1) T. Sheppard et al: JISI, (1970) P 797

2 ) 松野：鉄と鋼，65(1979)P 599

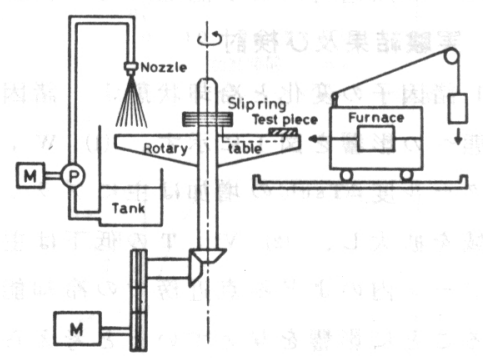

図 1 実験装置概略

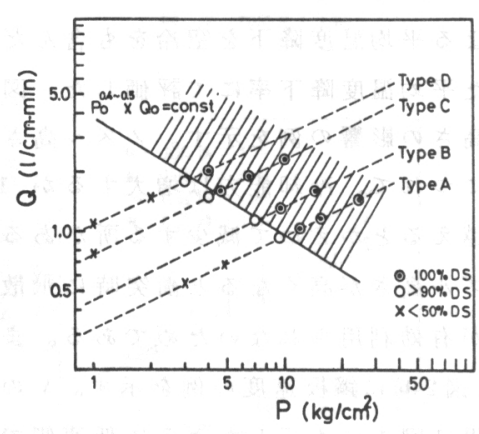

図 2 スプレイ条件とスケール 剝離の関係

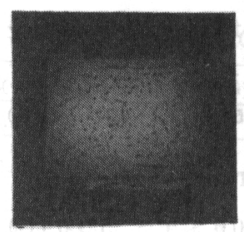

噴射前

(ノズル C , 噴射圧 $4.6 \mathrm{~kg} / \mathrm{cm}^{2}$ ) 写真 1 スプレイ噴射前後の 表面状態 


\section{（356）連続焼鈍法による高張力薄鋼板の製造}

669.14.018.292: 669.14-415: 621.783.223

' $80-\mathrm{S} 957$

メッキライン改造による高張力鋼板の製造ーI

住友金属（株）和歌山製鉄所済木捷郎 嶋田泰雄 $\bigcirc$ 永井秋男 中央技術研究所 岡本篤樹 長尾典昭

\section{I 緒言}

近年、自動車の車体軽量化および衝突強度の改善のため高張力薄鋼板が多量に使用されつつある。一 般に、60kg 似以上の引張強さを有する鋼板の製造には冷却速度の速い連続焼鈍法が有利であるので、 現有の溶融亜鉛メッキラインを改造し、非メッキで比較的板厚が厚く、かつ加工性の良好な高張力薄鋼 板が製造できるようにした。こてでは、改造内容と本ラインによる特徵ある製品として製造した引張強 さ $100 \mathrm{~kg}$ 和級超高張力鎆板について報告する。霓团気ガス出口

\section{II 改造内容}

困1 亿示すように、和歌山製鉄所№. 2 ガ ルバーラインの低温保持帯後部に出口シー ルとターンアップロールを新設し、鋼帯が 亜鉛浴槽に浸漬するととなく大気中に出る ように改造した。熱履歴の一例を図 1 の(A) に示す。

\section{III試作結果}

試作の結果、引張強さ $60 \sim 120 \mathrm{~kg} / \mathrm{mh}$

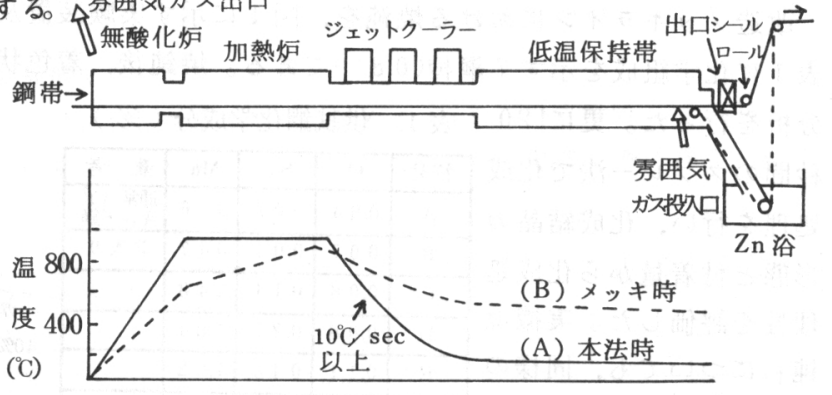

で、板厚 $0.8 \sim 3.2 m m$ の強度一延性バラン

スの良好な各種熱延および冷延高張力鋼板が製造できた。

特に、乙の中で最も高い強度を得た $100 \mathrm{~kg} / \mathrm{mk}$ 級冷延の 化学成分と引張試験值例を表 1 と表 2 亿示す。鋼板はAc3 変 態温度以上に加熱後急冷されているため、写真 1 に示すよう に、そのミクロ組織はベイナイトを主とするものである。

本鎘板をモデル型ドアガードバー状にプレス成形し、その 破壊テストを行なった。破壊テスト時の荷重と変位量との関 係を図 2 亿示す。従来の歪取焼鈍法による銅板に比較して本 鋼板は割れにくく変形能が大きく、目的に適した材料と言え る。

\section{IV 結言}

溶融要鉛メッキラインを改造 し、主に高強度で板厚の厚い複 合組織鋼板の製造を行なった。

ての内、特に $100 \mathrm{~kg} / \mathrm{mh}$ 級鋼 板はドアガードバー等の用途に 勝れた性質を示した。

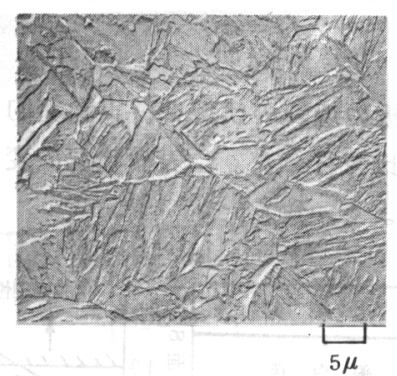

写真 1. 100 キ口級鋼板 のレプリカ組織

表 1. 化学成分例 ( w t \% )
\begin{tabular}{|c|c|c|c|c|c|}
\hline $\mathrm{C}$ & $\mathrm{Si}$ & $\mathrm{Mn}$ & $\mathrm{P}$ & $\mathrm{S}$ & sol.AQ \\
\hline 0.13 & 0.50 & 2.61 & 0.023 & 0.004 & 0.045 \\
\hline
\end{tabular}

表 2. 引張特性值例 ( J I S 5号)

\begin{tabular}{|c|c|c|c|c|c|}
\hline $\begin{array}{c}\text { 板厚 } \\
(\mathrm{mm})\end{array}$ & $\begin{array}{c}\text { 引張 } \\
\text { 方向 }\end{array}$ & $\begin{array}{c}\mathrm{Y} . \mathrm{S} \\
(\mathrm{kg} / \mathrm{mb})\end{array}$ & $\begin{array}{c}\text { T. S } \\
(\mathrm{k} g / \mathrm{min})\end{array}$ & $\begin{array}{c}\mathrm{E} \ell \\
(\%)\end{array}$ & $\mathrm{Y} . \mathrm{R}$ \\
\hline 1.2 & $\mathrm{~T}$ & 73 & 105 & 16 & 69.5 \\
\hline
\end{tabular}

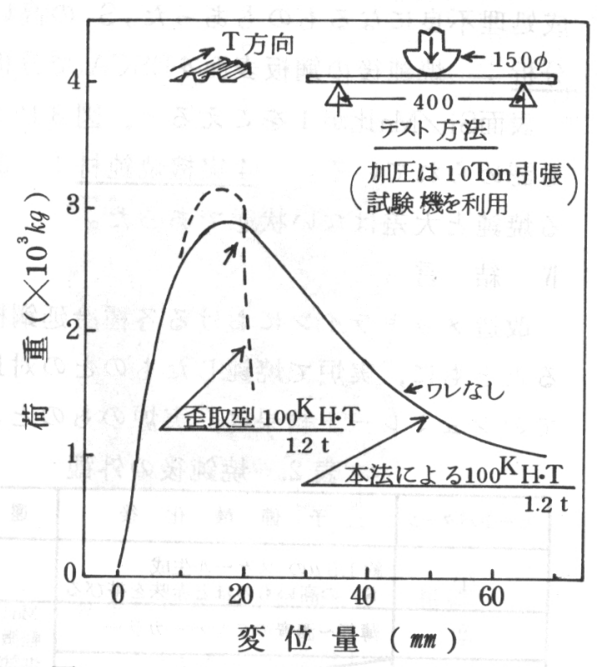

図2. モデルドアガードバーによる破壊 
ーメッキライン改造による高張力鋼板の製造 - II

住友金属工業(侏中央技術研究所松野二三朗 錦田俊一 薄木智亮 若野茂 和歌山製鉄所啮谷俊昌

\section{I 緒 言}

酸化されやすい $\mathrm{Mn}, \mathrm{Si}$ を多く含む高張力冷延鋼板は, 焼鈍時に, 着色が生じやすいという問題があ る。そてで,てれらの鋼板を改造メッキラインにて焼鈍した際の挙動について, 実験室的に検討すると ともに，実炉で焼鈍したものと比較した。

\section{II 実験装置と実験条件}

改造メッキラインにおける焼鈍を，図１亿示す実験装置及び実験条件でシュミレートした。供試鋼は 表 1 亿化学組成を示す 7 鋼種 $(0.8 \mathrm{t})$ である。焼鈍後, 着色状況の観察, ミク口観察, ESCA による表面 分析を行った。更に120 表 1 . 供試鋼化学成分 $(\%)$

秒間のスプレー法で化成 処理を行い, 化成結晶の 形態之付着量から化成処 理性を評価した。実機焼 鈍材についても, 同様の 調查を行った。

\section{III 実験結果}

\begin{tabular}{|c|c|c|c|c|}
\hline 符号 & C & $\mathrm{Si}$ & $\mathrm{Mn}$ & 備 考 \\
\hline A & 0.04 & \begin{tabular}{|l|l|}
0.02 \\
\end{tabular} & 0.16 & 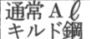 \\
\hline B & 0.07 & 0.04 & 0.47 & P入 \\
\hline C & 0.06 & 0.14 & 2.43 & \\
\hline $\mathrm{D}$ & 0.08 & 0.27 & 1.24 & \\
\hline$E$ & 0.11 & 0.43 & 1.62 & \\
\hline$F$ & 0.11 & \begin{tabular}{|l|l|}
0.76 \\
\end{tabular} & 1.73 & \\
\hline $\bar{G}$ & 0.10 & 0.03 & 0.93 & \\
\hline
\end{tabular}

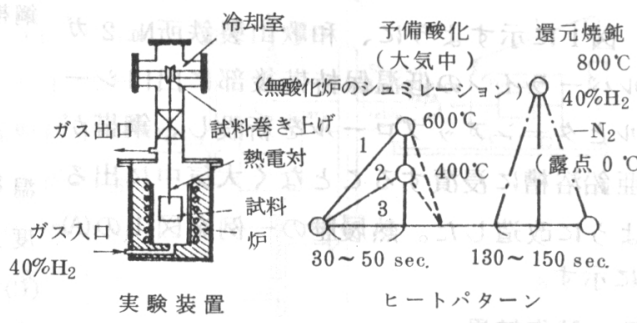

(1)表面状況：予備酸化により生成するスケールの量により，還元後の外観が異なった。(表 2 ) スケ 一ルが厚い場合には銀白色となり,スケールが薄い場合及び予備酸化なしの場合には, Mn, Siの高い供 試鋼では露点が高いため $\left(0^{\circ} \mathrm{C}\right)$ 軽い着色が生じた。銀白色となったものの表面には, 純鉄層が生成して いた。軽微な着色が生じたものでは, 約 $0.1 \mu \sim 1 \mu$ の大きさの酸化物が生成していた。図 2 ) 酸化物 はスピネル型酸化物及び $\mathrm{Mn}$ シリケートであった。 (2)化成処理性：良好な表面となったむののみなら ず，軽微な着色が生じたものでむ，化成処理性は，大むね良好であったが，銀白色になったものは，化 成処理不良になるものもあった。Siの高い供試鋼では, 化成結晶が大きくなる傾向を示した。 (3)表面 分析： 焼鈍後の鋼板表面をESCA で分析した結果，表面にMn, S 泇富化しているととがわかった。

表面 $\mathrm{Si} / \mathrm{Mn}$ 比が 1 をこえると, 図 3 亿示すように化成処理性が悪化した。この傾向はバッチ焼鈍材て 屯認められている。 $(4)$ 実機焼鈍材：改造メッキラインで製造した鋼板表面の状況は, 実験室におけ る焼鈍と大差はない状態であった。

IV 結 言

改造メッキラインにおける各種冷延鋼板の焼鈍の状況を, 実験室的に検討す るとともに，実炉で焼鈍したものとの対比を行った。表面状況の変化につい てのシュミレート結果は, 実炉のものとよく一致した。

表 2. 焼鈍後の外観

\begin{tabular}{|c|c|c|}
\hline ヒートパターン & 予 備 酸 化 後 & 還 元 焼 鈍 後 \\
\hline (1) & $\begin{array}{l}\text { 約 } 1.5 \mu \text { スケール生成 } \\
\mathrm{Si} \text { の高いものほど赤味を帯びる }\end{array}$ & 銀 白 色 \\
\hline (2) & 薄茶〜濃青のテンパーカラー & \multirow{2}{*}{$\begin{array}{l}\mathrm{Mn}, \mathrm{Si} \text { の高いものでは } \\
\text { 軽微な着色発生 } \\
\text { 供圾鋼Cは黒色,他泊青色 } \\
\text { で Siが少ないはと軽微 }\end{array}$} \\
\hline (3) & & \\
\hline
\end{tabular}

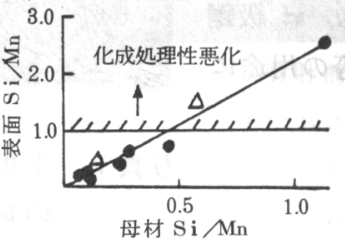

母材 $\mathrm{Si} M$ 図3. ESCAによる分析 結果
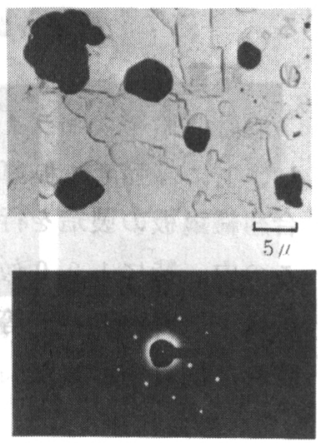

図 2. 表面に生成した 酸化物 (スピネル型酸化物) 
1.緒言：加熱师の酸化性雾囲気で鋼板表面硬化のための拡散元素を安定してつくることは容易ではない。そ こて、酸化性雾囲気でも安定した合金化拡散層をつくる方法として、被覆剤に溶融フラックスを配合し、炭化々 イ素を主体とした溶融フラックスを含む被覆剤が加熱炉の温度で融涬化することにより酸化を防止しながら溶融 搪散させることを見出した。

本実験は、融涬化した状態での各種元素の拡散の挙動、適正条件を調査したものであり、また、表面硬化鉿板 製造への適用実験を試みたので、その結果を報告する。

2. 実験方法： S S - 41, の実験用スラプ鋳片（100t×200×400 mm）の上面を粗研磨し、溶接ビードで10分 割したのち、各区画に炭化ヶィ素を主体とした被覆冎を水ガラスで混練りし塗布した。

そして、試験材を実機のプッシャー型加熱炻にそう入し、設定温度 $1280{ }^{\circ} \mathrm{C} \pm 10{ }^{\circ} \mathrm{C} 、$ 炉内時間 $120 \pm 10 \mathrm{~min}$ で処理し、その試験片を $160^{\circ} \mathrm{C} / \min て ゙ 400{ }^{\circ} \mathrm{C}$ まで水冷して採取し、合金桩散部の成分、硬度、浸入深さ、組織 について調查した。

表1。溶融フラックスの化学成分 $(\mathrm{W} t \%)$

被覆剤に使用した溶融フラックスは、 あらかじめ溶融し、0.25 mmに粉砕した もので、化学成分を表】に示す。

\begin{tabular}{|c|c|c|c|c|c|c|}
\hline フラックス 成分 & $\mathrm{SiO}_{2}$ & $\mathrm{C} \boldsymbol{a} 0$ & $\mathrm{MnO}$ & $\mathrm{Al}_{2} \mathrm{O}_{3}$ & $\mathrm{MgO}$ & $\mathrm{TiO}_{2}$ \\
\hline 酸性型の場合 & 37.0 & 10.3 & 38.7 & 3.8 & 1.2 & - \\
\hline 塩基性型の場合 & 29.2 & 30.5 & 14.8 & 8.4 & 3.5 & 2.0 \\
\hline
\end{tabular}

3. 実験結果

(1)溶融拻散した合金成分は、Si C みの場合、地鉄のほかに C と Siを主体とした元素からなり、気泡のな い厚みの均一な融点 $1150{ }^{\circ} \mathrm{C} の$ 合金層が得られた。

(2)被覆剤中の溶融フラックスが酸性型おょび塩基性型いずれの場合も、SiC配合成分は、40〜50\%が 最適範囲となった。

(3) スラプ録片に被覆 表 2。溶融拡散による合金層の成分と硬度の一例

郕を盗布し、縞鏎板への 圧延実験をした結果 $6 m m$ 鑈板の表層には約 $60 \mu_{\mathrm{m}}$ 厚のSiと $\mathrm{C}$ の拡散した 表面硬化層が得られた。

\begin{tabular}{|c|c|c|c|c|c|c|c|c|}
\hline & \multicolumn{3}{|c|}{ 元 } & \multicolumn{4}{|c|}{$(w t \%)$} & \multirow{2}{*}{$\begin{array}{c}\text { 硬 度 } \\
\text { (ビツカース) }\end{array}$} \\
\hline & C & $\mathrm{Si}$ & $\mathrm{Mn}$ & $\mathrm{P}$ & $\mathrm{s}$ & $\mathrm{Cr}$ & W & \\
\hline 母材 (S S-4 I) & 0.14 & 0.22 & 0.58 & 0.022 & 0.017 & - & - & $150 \sim 190$ \\
\hline $\mathrm{SiCのみ}$ & 2.35 & 5.62 & 1.92 & 0.021 & 0.014 & - & - & $340 \sim 380$ \\
\hline $\mathrm{SiC}+\mathrm{F} \theta-\mathrm{Cr}$ & 2.11 & 5.70 & 1.65 & 0.020 & 0.016 & 2.04 & - & $400 \sim 480$ \\
\hline $\mathrm{S} i \mathrm{C}+\mathrm{F} \theta-\mathrm{W}$ & 2.05 & 5.35 & 2.03 & 0.020 & 0.015 & - & 0.75 & $600 \sim 720$ \\
\hline
\end{tabular}

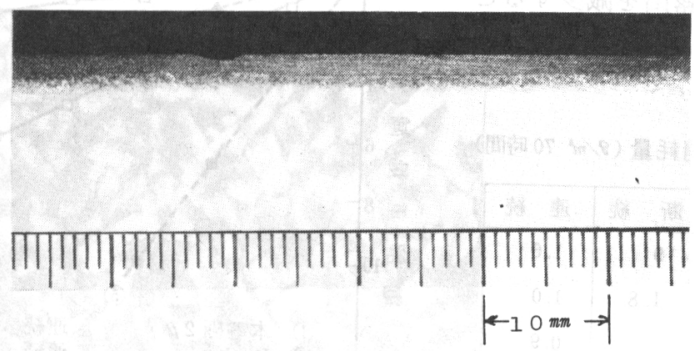

写真 1. 合金化桩散層の断面マクロ組織

$$
\text { （ SiCのみの場合） }
$$

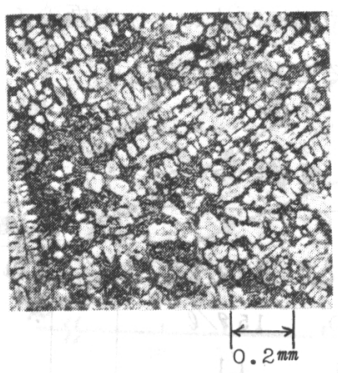

写真 2 . 合金化拡散層の断面ミクロ組織

$$
\text { （ Sicのみの場合） }
$$




\section{1. 序}

電気錫メッキ鋼板の製造において，可溶性電極（錫）のみではメッキ浴中の錫濃度が上昇するため，一部の電 解セルに不溶性電極を用いて錫濃度を制御している。てれらの電極は, チタン上に白金メッキを $3 \sim 5 \mu \mathrm{m}$ 電 気メッキしたもので耐久寿命が $2 \sim 6$ ケ月と短く長寿命型の不溶性電極が望まれている。又，近年白金価格の急 激な高騰に対処するため，白金メッキの厚みを減少する必要性も出て来た。

本研究は電極の寿命延長および白金の薄メッキ化を目的として開発した複合メッキ被膜を有する不溶性電極の 研究である。

\section{2. 研究の方法}

1）不溶性電極の作成

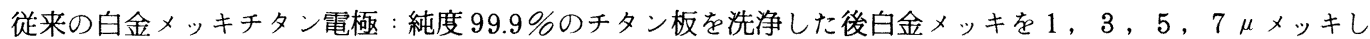
て使用した。白金メッキはジア之ノ亜硝酸塩浴を用いた。

本研究の複合メッキチタン電極 : 従来の白金メッキを $1 \mu$ メッキしたチタン電極の表面に $1 \mu$ の白金属系の金 属の塩化物を熱分解法によってコーティングした後更に $550^{\circ} \mathrm{C} 1$ 時間加熱した。比較のため白金メッキなしも行った。

2） 電解方法

錫メッキにおいては，一定の電流密度でメッキするために目付量により一部のセルに通電しない場合があり 不溶性電極に対する影響を考慮して連続通電，断続通電（50 分通電／10 分OFFの繰返し）の 2 つの電解法を探 用した。その他の電解条件は第 1 表に示した。

\section{3. 研究結果}

1）電極の消耗量：第 1 困に各種電極の電極消耗量の推移，第 2 表に 70 時間電解後の消耗量を示した。

第 1 図, 第 2 表から明らかな如く，不溶性電極の寿命に関しては，(1)連続電解，断続電解で差があり，断続電 解は電極の寿命が短い。(2)本研究の電極は薄メッキにも拘らず消耗量が少い。

2）電極の表面観察：走相型電顕によって各電極の表面を観察した結果，白金メッキ単独ではメッキ欠陌が無数 にあり, 電解によって陥が増大しているのに対し複合メッキ電極は, 電解前後でチタンの露出が殆どみられず 優れている。

以上の結果から，錫メッキの不溶性電極の寿命延長に関しては通電 しない時の電位逆転防止および電極のチタン素地の露出を減少すると とが有効であるととが分った。

第 1 表 電 解 条 件

\begin{tabular}{|c|c|c|}
\hline \multicolumn{3}{|l|}{ 電解液 } \\
\hline \multicolumn{2}{|c|}{$\mathrm{Na}_{2} \mathrm{SO}_{4}$} & $408 / \ell$ \\
\hline \multicolumn{2}{|c|}{$\mathrm{H}_{2} \mathrm{SO}_{4}$} & $15 \mathrm{~g} / \ell$ \\
\hline \multicolumn{2}{|c|}{$\mathrm{PH}$} & 1.1 \\
\hline \multirow{2}{*}{\multicolumn{3}{|c|}{ 電流密度 $30 \mathrm{~A} / \mathrm{d} m^{2}$}} \\
\hline & & \\
\hline \multicolumn{3}{|l|}{ 極 間 } \\
\hline
\end{tabular}

第 2 表 電極消耗量 $\left(g / m^{2} 70\right.$ 時間)

\begin{tabular}{|c|c|c|c|}
\hline 電 & 極 & 断 続 & 連 続 \\
\hline $\mathbf{P t} \times ッ キ 1$ & $1 \mu$ & 9 & 1.6 \\
\hline & $3 \mu$ & 1.8 & 1.0 \\
\hline & $5 \mu$ & & 0.9 \\
\hline & $7 \mu$ & & 0.85 \\
\hline 本 電 極 2 & $2 \mu$ & & 0.5 \\
\hline
\end{tabular}

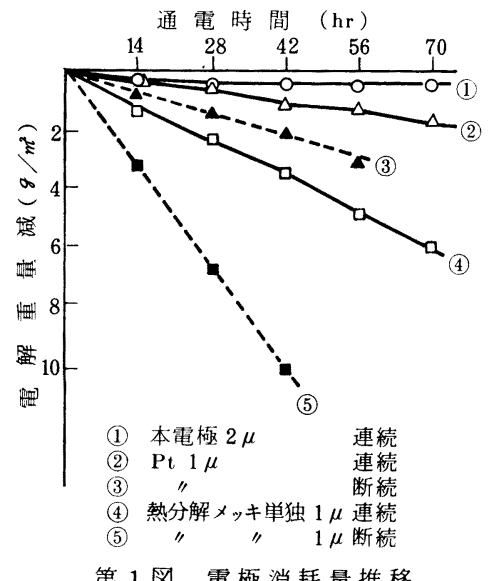

第 1 図電極消耗量推移 
(360) ロールコーティング法による片面溶融亜鉛メッキ鋼板の開発

新日鐵名古屋製鐵所 $○$ 金丸辰也。高木正明。須原道憲 藤原俊朗。小野田正已。村上伸和

1. 緒 言

片面溶融覀鉛メッキ鋼板は自動車用防錆材料として現在研削法により工業生産されているが,より合 理的な新しい製造法の研究を行なってきた。溶融亚鉊浴に一部浸漬し回転するコーティングロールを銅 带片面に接触させてメッキする方法一ロールコーティング法一が極めて有望であることがわかったので 報告する。

\section{2. 実験方法}

ゼンジミア式連続悪鉊メッキラインに図1 亿示す装置を設け，片面メッキ実験を行なった。 $\mathrm{N}_{2}$ ガス雾 井気中で鋼帯をラインスピードと同周速，同一方向に回 転するコーティングロールに弧状に接触させて片面メッ キし，采外で $\mathrm{N}_{2}$ ガスワピングすることにより目付量の 調整を行なった。得られた片面メッキ鋼板の目付量を測 定し, メッキ面および非メッキ面の性状を調查した。

\section{3. 実験結果}

メッキ面は全巾に亘って均一完全にメッキされ，通常 の浸漬メッキと変らない外観であった。非メッキ面には 全く要鉛は付着しなかった。図 2 とはメッキ面の目付量 とラインスピード, $\mathrm{N}_{2}$ ガスイピング圧力の関倸を示す。

メッキ密着性は侵入板温の広い範囲に亘って良好であ り,ポールインパクト試験で全く剥離はなかった。 $\mathrm{Fe}$ $\mathrm{Zn}$ 合金層の形成は健全であった。

非メッキ面の表面粗さプロフィルは冷延鋼板のそれと 全く同一であり，覀鉛は㭘出されなかった。リン酸塩処 理性, 染装性は冷延鋼板と同等以上の性能を示した。
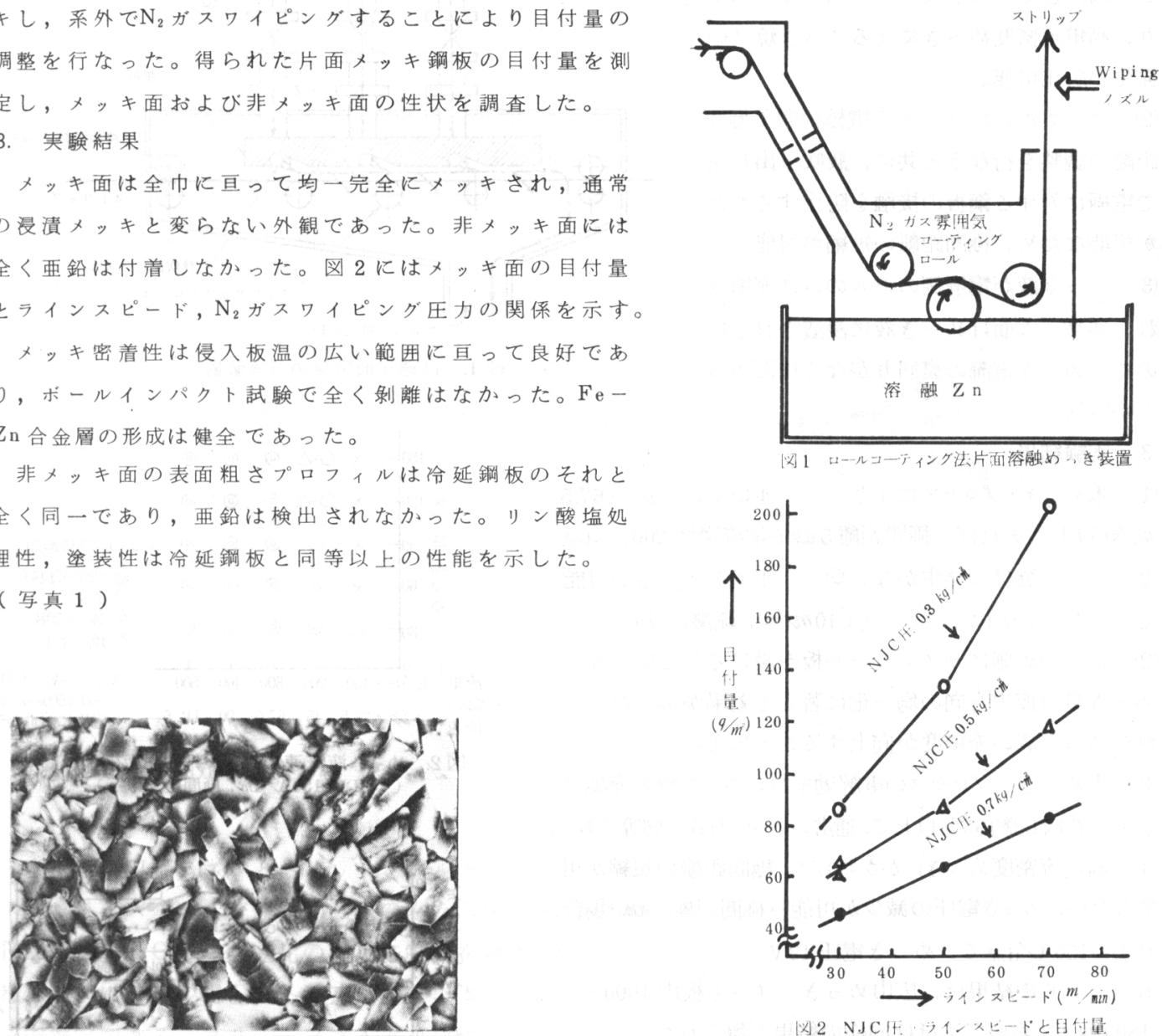

写真 1. リン酸塩処理後の非メッキ面

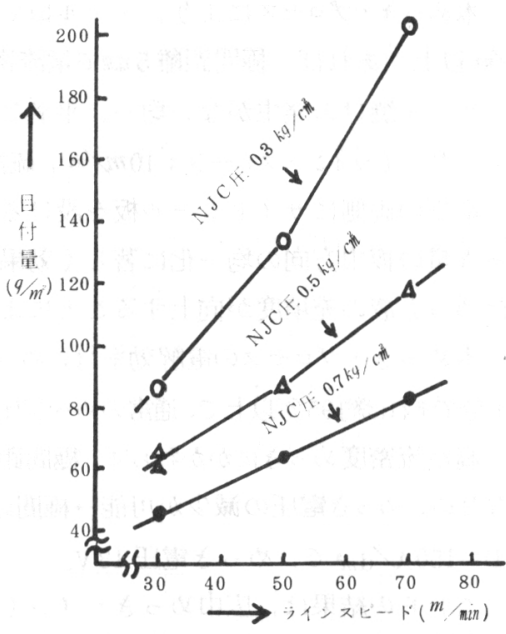

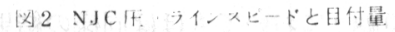

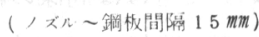

(亜鉛鉄系リン酸塩処理) $\times 2000$ 


\section{（361）電気めっき法による高速片面亜鉛めっき・プロセスの開発}

新日鐵 八幡 ○樋口征順, 田野和広, 蒲田 稔 榢本幸雄, 野村幸雄, 永井新二

1. 緒 言 自動車用防錆鋼板としての片面覀鉛めっき鋼板は, 一般に厚めっき材が使用される。そのために, 電気めっき法では, 高電流密度めっきによる高速化が生産性向上のために是非必要である。その場合, (1)めっき 電圧の急上昇による電力消費量の増加が著しいので, 極間距離の短縮によるめっき電圧の減少が可能なめっき方 式。(2)黒色粉末状のめっき焼けの発生を防止しうるめっき方式。の開発が望まれる。てれらに対処して, 効率的 な高電流密度による高速めっきが可能な片面電気要鉛めっき・プロセスの開発，検討を行なったので報告する。

2. 実験方法 (高速片面電気めっき装置の開発と特徵)

図 1 亿示すような片面電気めっき装置を以下の考え方で開発, そのめっき・プロセスの検討を行なった。

(1) 電極内部に配置された液吹出しノズル から高流速でめっき液を吹き出すととによ り, 高電流密度めっきによるめっき焼けの 発生が防止可能。

(2) バックアップ・ロールと電極の間で極間 距離の調整を行なうと共に, 液吹き出し圧 で電極に対する鋼板の接触を防止するとと が可能なため, 極間距離の短縮が可能。

(3) めっき液が電解側のセルのみに充填さ れ，非めっき面はめっき液に浸漬されない ので, めっき電流の裏回りがなく片面めっ

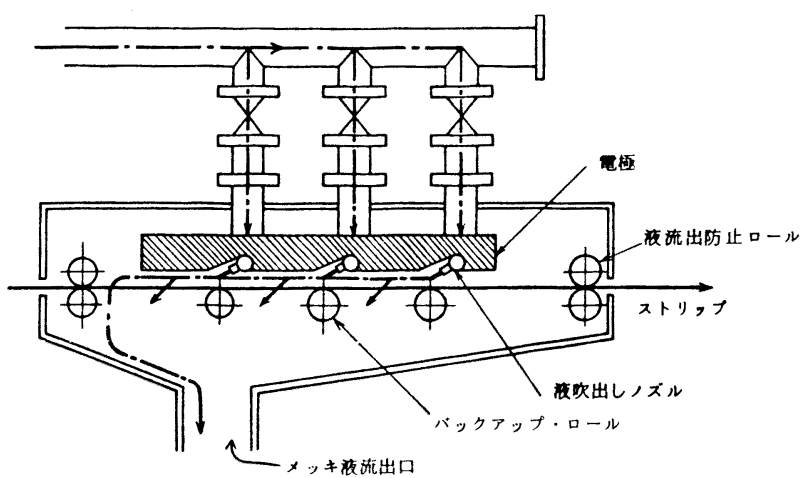
きが容易。

\section{3. 実験結果}

(1) 本めっき・プロセスにより，ノズルロでの流速が 67.5 $m /$ min 以上であれば, 極間距離 $5 \mathrm{~mm}$ で電流密度 $200 \mathrm{~A} / \mathrm{d}^{2}$ 迄,めっき焼けの発生がない均一, 平滑なめっきが可能 であった。(ライン・スピード；10 m/min，硫酸浴使用）

(2) 電極の両側にサイドシール板を設けるととにより, めっき量の板巾方向の均一化に著しく効果があった。と れはめっき液の充填度が向上することによる。

（3）本めっき・プロセスの電解効率は，めっき液の充填度 が十分であれは約 $95 \%$ 以上で, 通常のめっき方式と同等である。 (4) 高電流密度めっき亿か力からず，極間距離の短縮が可 能なため, めっき電圧の減少が可能 極間距離 5 mmの場合, C. $\mathrm{D}=150 \mathrm{~A} / \mathrm{dm} \mathrm{m}^{2}$ で，めっき電圧 $13 \mathrm{~V}$ 。

(5) 乙れらの結果は, 広巾めっきライン（板巾1000～ $1800 \mathrm{~mm})$ においてもほぼ同様の結果が得られた。

（6）非めっき面は端部1２mm巾を除いて, 亜鉿の付着は 全くなく,また燐酸塩処理性, 塗装後耐食性は良好であった。

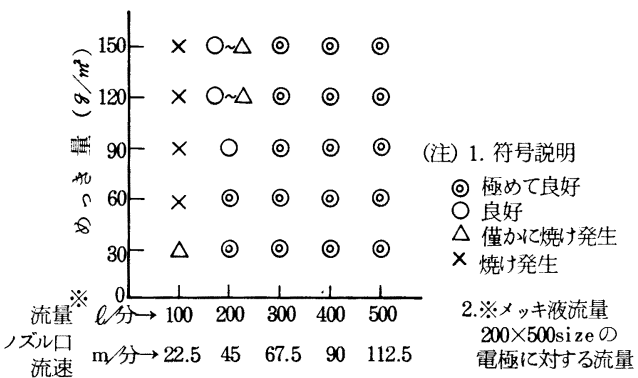

図 2. めっき液流速のめつき外観に及ぼす影響 ( C. $\mathrm{D}=150 \mathrm{~A} / \mathrm{d} \mathrm{m}^{2}$ 、極間距離 $5 \mathrm{~mm}$ )

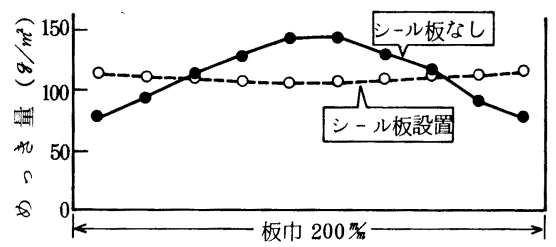

図3.メッキ量分布の均一性に及ばすサイド シールの効果 $\left(\mathrm{C} . \mathrm{D}=150 \mathrm{~A} / \mathrm{d} \mathrm{m}^{2}\right)$ 


\section{$(362)$}

$621.357 .7: 669.587: 532.525: 532.57$

' $80-\mathrm{S} 963$

高速電気亚鉛メッキの研究( 第了報)

〜各種ノズルによる噴流の流速分布〜

日本鋼管怢技術研究所福田脩三○大久保豊

渡辺勉

I 緒言：電気两鉛メッキラインを高速化させるための噴流 供給方法については、前報で、円管ノズルとダミ一電極を用 1.0 いた場合について述べた。本報では、さらに、電極間のメ キ液流速の均一化をも考慮した各種ノズルについて検討し、 流速の均一化、効率化を達成でをる噴流供給方法について、 整理したので報告する。

II 実験方法: 実機メッッキ槽の実物大模型を用い、使用流体 0 は水、流速測定は、熱線流速計を用いて実験した。

$$
\begin{array}{rr}
\text { ノズル開口寸法: 長辺 } 400 \mathrm{~mm} \sim 55 \mathrm{~mm} & \text { ( W ) } \\
\text { 短辺 } 15 \mathrm{~mm} \sim 2.5 \mathrm{~mm} & \text { ( D ) } \\
\text { ノズル出口流速: }: 13 . \sim 2 \mathrm{~m} / \mathrm{sec} & \text { ( Uo ) }
\end{array}
$$

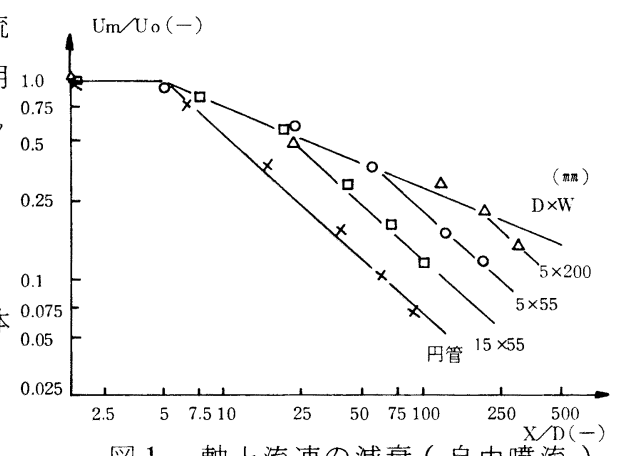

図 1 軸上流速の減衰 (自由噴流)

I実験結果図1亿、上記各種ノズルイついて、自由噴流 (アノード、ストリップがない場合)の軸上流速の减衰を示 した。ノズルの長辺W $\times 5$ の位置から、噴流は、2 次元流か ら 3 次元流飞移る。噴流が電極間飞制約された場合も、減衰 の程度は弱をるが、上記と同じ傾向を示す。

図 2 は、噴流の水平方向の仏がりを示したもので、ノズル の長辺Wによって、広がりは、㴗一義的に決をる。流速分 布は、Xの $5 \times W$ 位置を境てして、それより上流側では台 形分布、下流側では正規分布に洼倿近似でをる。以上の結果 ををとめて次式を得た。

$\mathrm{U}=\mathrm{Um} \cdot \mathrm{f}$

$$
\begin{aligned}
& \mathrm{Um}=\mathrm{Uo} \\
& \mathrm{Um}=\mathrm{Uo}(\mathrm{X} / 5 \mathrm{D})^{-\mathrm{A}} \\
& \begin{array}{l}
\mathrm{O} \leq \mathrm{X} \leq 5 \mathrm{D} \\
5 \mathrm{D}<\mathrm{X} \leq 5 \mathrm{~W}
\end{array} \\
& f=1 \quad|y|<y c \\
& f=\frac{y b-y}{y b-y c} \quad y c<|y|<y b \\
& \mathrm{Um}=\mathrm{Uo}(\mathrm{W} / \mathrm{D})^{\mathrm{B}-\mathrm{A}} \cdot(\mathrm{X} / 5 \mathrm{D})^{-\mathrm{B}} \quad 5 \mathrm{~W} \leq \mathrm{X} \quad f=\exp \cdot\left\{-\mathrm{C}\left(\frac{\mathrm{y}}{\mathrm{x}}\right)^{2}\right\}
\end{aligned}
$$$$
700 \begin{cases}\mathrm{yb} / \mathrm{W} / 2, \mathrm{yc} / \mathrm{W} / 2 \\ \mathrm{~b} / \mathrm{W}(\rightarrow)\end{cases}
$$

\begin{tabular}{|c|c|c|c|c|}
\hline ノズ & $\begin{array}{l}\text { ノズル } \\
\text { 出口流速 }\end{array}$ & 吐出圧 & 流 量 & 動力比 \\
\hline $\begin{array}{c}\text { mang } \\
18 \text { 円管 } \\
\text { トレA }\end{array}$ & $9.24 \mathrm{~m} / \mathrm{s}$ & $0.436 \mathrm{~cm}$ & $1.69 \mathrm{~m} /$ 分 & 1 \\
\hline $\begin{array}{ll}\mathrm{W} \times \mathrm{D} & 2 \text { 本 } \\
780 \times 3^{\text {man }} & \text { トレ1 }\end{array}$ & 7.35 & 0.276 & 2.06 & 0.77 \\
\hline
\end{tabular}

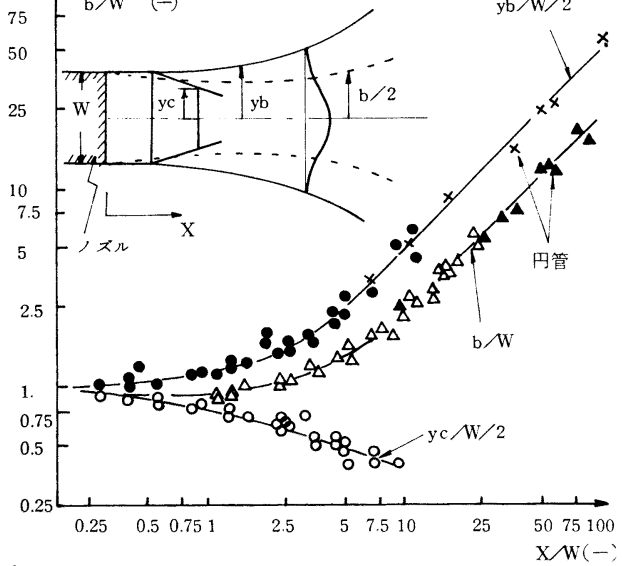

表 1 亿、円管ノズルとスリットノズルとの比較を行なった。 スリットノズルは、流速の均一化のみならず効率的にも良い。表1 スリットイスルと円管ノスルの比較 IV 結言：EGLの高速化のためと噴流を適用する場合、各 種ノスルによって得られる流速分布は、本モデル式に上り、 汪浮推定できる。スリットノズルは、従来の円管ノズルに比 べて、均一化、効率化の点で優れている。 参考文献）福田ら；鉄と鋼 $66($ ，8 0 ) S 497 


\section{1. 緒言}

厚板压延における平面形状を改善し、压延歩留りを向上させるととを目的として、第 1 報では、スト レート压延におけるクロップ・珙形度の代表值を推定可能とする各パスどとの重ね合せ方式を確立、第 2 報で、この方式を平面形状プロフィル全てに適用し、かつスラブを転回する巾出し压延を含めた厚板 压延中の平面形状の形成過程を定量的に把握するプロフィル予測方式を確立した。。本報告では、この予 測モデルを用いて、平面形状を最良とすべくパススケジュールの最適化を行ない、この結果を当社厚板 工場に適用し効果のあるととを確認した。

2. パススケジュールの最適化

京浜厚板压延機の代表的パススケジュールによる調整压下量 と歩留りの関係を予測モデルによって評仾し、図 1 に示す結果 から次の結論を得た。

○幅出し比が小さい場合、歩留りは調整圧下量によらず一定と なる。

○幅出し比が大をくなるに従い、歩留りにおよほす調整压下量 の影響は大をくなり、㑉整压下量の増加につれてタイコ型形状 が減少し、歩留りは直線的に向上する。

○調整圧下量を、ロール胴長、スラブの転回限度を考慮して、

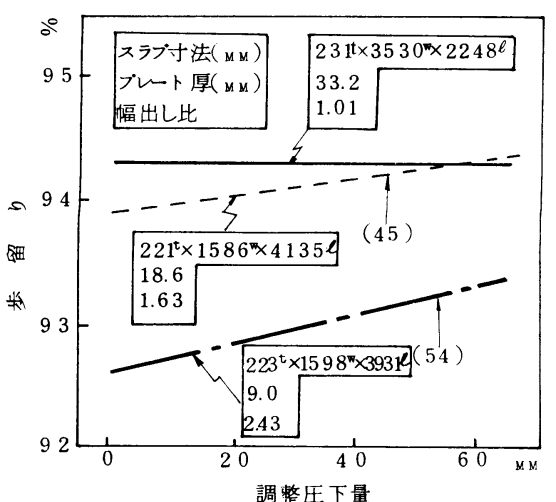

図 1. 調整圧下量と歩留り 可能な限り大をくするととにより、平面形状が改善され、压延歩留りが向上する。

\section{3. 京浜厚板工場への適用}

表 1 亿示すように、4 種の幅出 し方法にパターン化し、これらに 対応した調整圧下量の最適値の算 出規準を明確にした後オンライン 化をはかった。この結果、図 2 に 示すように、洪形度に関しては、 幅出し比が 1.65 までッヅミ型の高 歩留り形状が得られたため（従来は1.40をで）従来压延に比し てタイコ型形状が減少し、歩留り向上を得た。また、クロップ 長さは、全対象量にわたり半減した。

\section{4. 結言}

平面形状に関する最適パススケジュールを京浜厚板工場に適 用した結果、異形度およびクロップ長さとも従来の厚板压延と 比較して大幅に減少し、压延歩留り向上が達成できた。

\section{[文献] 1) 棡戸・中内他鉄と鋼 1976 P 238. 2) 剛戸・有泉鉄と鋼 1978 P 278 .}

* : 最初の長手方向压延から幅出し压延開始までの压下量。

表 1 . 幅出し方法

\begin{tabular}{|c|c|c|c|c|c|c|c|c|c|}
\hline フェーズ & SG & 一压延 & -1 & L斥砸 & & 圧延 & & 一正延 & \multirow{2}{*}{ 内 容 } \\
\hline & Bo & & $\mathrm{B}_{1}$ & & $\mathrm{~B} 2$ & & & & \\
\hline $\mathrm{LOO}$ & $\mathrm{H}_{\mathrm{B}}=\overline{\mathrm{F}_{\mathrm{VO}}}$ & (幅出し) & タ-ン & 仕上げ & & & & & $\begin{array}{l}\text { 分塊材の横圧 } \\
\text { 調整圧延なし }\end{array}$ \\
\hline LXX & & $H_{B}=S_{V_{0 O}}$ & צ-ン & 調整 & ターン & (幅出し) & タ-ン & 仕.上げ & $\begin{array}{l}\text { 連銕材の横压. } \\
\text { 限界まで調整压延 }\end{array}$ \\
\hline WOO & & $H_{B}=\frac{\overline{\mathrm{VO}}_{2}}{\mathrm{WB}_{1}}$ & 夕-ン & \begin{tabular}{|c|} 
(幅出し) \\
\end{tabular} & ターン & 仕上げ & & & $\begin{array}{l}\text { 分塊·連錪材の稆厈 } \\
\text { 調整圧延なし }\end{array}$ \\
\hline WXX & $\mathrm{H}_{3}=\frac{\mathrm{SvO}_{1}}{\mathrm{WB}_{1}}$ & 調整 & タ-ン & \begin{tabular}{|c|} 
(幅出し) \\
1 \\
\end{tabular} & ターン & 仕上げ & 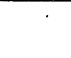 & & 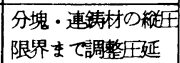 \\
\hline
\end{tabular}

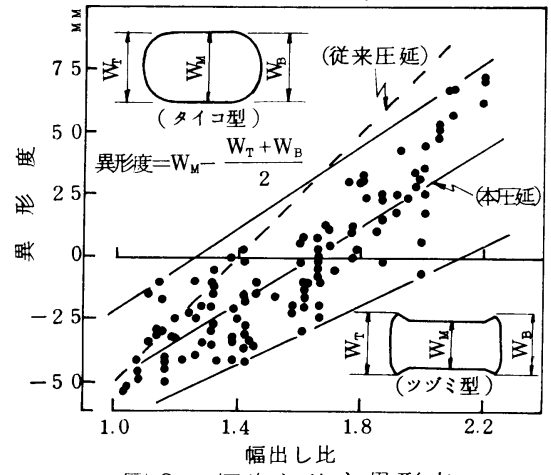

困 2. 幅出し比と異形度 
$621.771 .237: 531.717 .2: 535-34$

' $80-\mathrm{S} 965$

（364） ホットストリップのオンラインプロフィール測定

川崎製鐵料）千菜製鐵所由宫稔士O御噼尚 峰松隆嗣 片山宏平

1 緒言川崎製鐵千葉製鐵所第2热延設備（昭54年4月），第1熱延設備（昭５５年3月）に木 ットストリップのオンラインプロフィールメータを導入した。プロフィールメータは順調な連転状况 下にめり重要な品管管理計測器として使用している。本報ではプロフィールメータのシステム構成， プロフィールメー夕の仕样およびオフライン，オンラインでの測定結果について報告する。

2 プロフィールメータのシステム楧成仕上ミルの出側に2台のX線㚖さ計を設置し，1台を中央 に固定とし1台を横方向に走らせそ の差をとる。プロフィールの算出と 台車走行シーケンス制御用にマイフロ コンピエータを使用している。出力は 記録計にプロフイールを出カし、クラ ウンとウェッジをミル計算機に出力する。

3 オフラインプロフィール测定結果

$3.14 m m$ のテストサンプル板上に 人工ハイスポットをつくり検出能力を

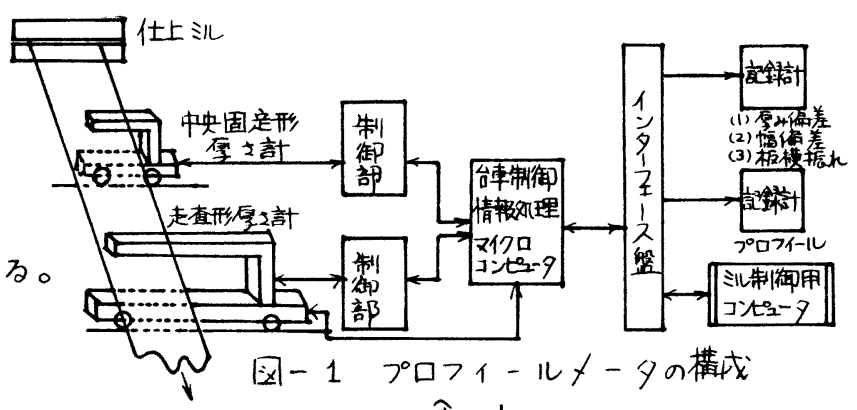
調査した結果を目ー2に示す。

4 オンラインプロフイール測定結果

(1) プロフィールの測定精度

ストリップ上に走査形夏さ計の走直軌跡を推定し，下工程 のと楾夏さ計でプロフィールを測定した結果を园ーろに不す 。秸果は非常によく一致している。

(2) クラウン测定精度

コイル中央部でサンプル板を取り，ハンドマイクロメータ

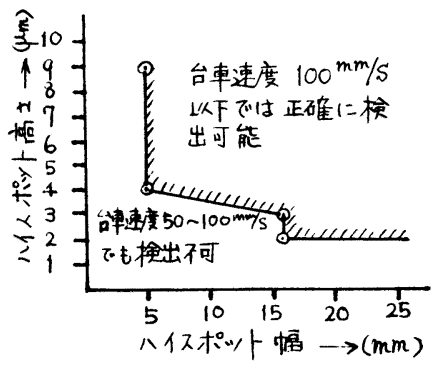

とプロフイールメータの記録チャートを比較した。板端から 20，30，40 m m 基準として各マフラウンを求めた結

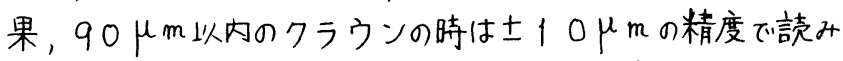
取水ることが判つた。板端より $30 \mathrm{~mm}$ を基萍とした時の7 ラウンのチャート読取り精度を图ー4に示す。

（3）異常突起（ハイスポット）検出精度 ハンドマイフロメータとプロつイールメータの記録チャー トを比較した。5 $\mu$ m高さ，10 m m 幅が挨出できる。

5 結言千莱製鐵所熱延ラインにプロフイールォータを導入

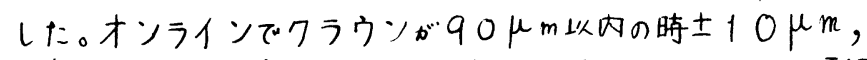
異常突起は $5 \mu m$ 高さ, $10 \mathrm{~mm}$ 幅まで㛟出可能である。煩調 な逢轻状況下にあり重要な品筫管理計測器として使用している。 6 文献 正信 5 : 計74-[6]-3 X線プロフィール $x-9$

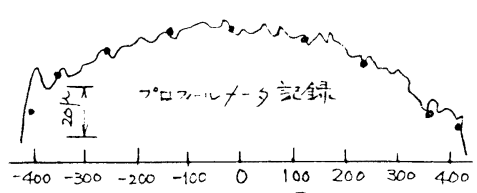

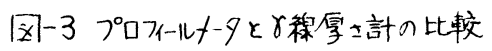

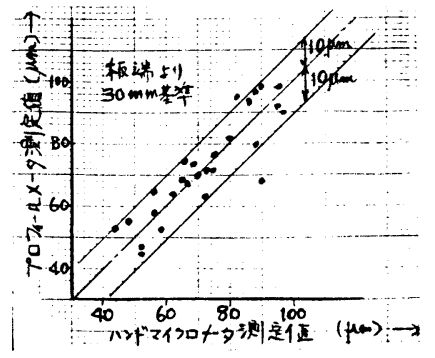

国-4 7ラウンの测定精度 


\section{I. 緒言熱延鋼板の板幅精度は,トリム工程での歩留を左右する最大の要因である} が，近年連鋳スラブの普及に伴らスラブ幅の集約及び，省エネルギー指向にょるスキッドマークの顕在 化により, 悪化の傾向にあった。鹿島熱延工場においては, 板幅精度を改善する手段として, 粗ロール エッジャーによる自動板幅制御システム（ A W C システム) を開発し, 実用化に成功している。

II. 粗圧延における幅挙動 エッシシング压延と水平圧 延の繰り返しで構成される熱延の粗圧延中の幅挙動を 把握するために，実ラインでのテストを行い，ドッグ ボーンの挙動を考慮した数式モデルを開発した。スキ ッドマークによる幅変動発生機構につけては, 従来一

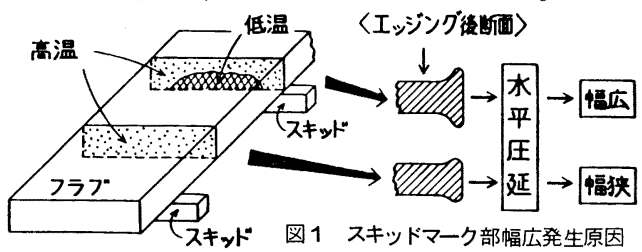
般的に考えられていた，スキッド部が高荷重であるゆ え生じるエッジャーのミルスプリングの差によるより も，むしろ図1. K示すどとく，ドックボーンの盛り 上りの差による事を見的出した。

III. AWC 制御システム鹿島熱延工場の粗ロール レイアウトを図 2 、に示すが，新をに設置した $\mathrm{R}_{3}$ 幅 計の偏差より， $\mathrm{R}_{6}$ 幅計の偏差を零にするよう飞 $\mathrm{E}_{4}$ の開度を制御する方式であり, 図 3 。《制御フロ一 を示す。ミドル部とは, 挙動が異なる先後端部の幅 変動は, 各エッシャ一での幅圧下量飞応じて, $\mathrm{E}_{4}$ の開度を急速開閉する制御方式である。んずれる制 御モデルの精度と並んで制御のポイントとなるのは ，材料と制御タイミングのマッチング精度であり， \pm 0.1 秒の精度が必要である。

制御スタンドの決定は, 制御性, 耐挫屈性および改 造規模を配慮した上， $\mathrm{E}_{4}$ とした。又，圧下方式は 低慣性高応答性電動機で十分効果が期待でをるとと から電動圧下方式を採用した。本システムの主要能 カとしては, 最大荷重 $170 \mathrm{TON}$, 最大圧下速度 $9.65 \mathrm{~mm} / \mathrm{S}$ (片側) である。図 4 .の例のよら飞, A W C 支使用すれば， $\mathrm{R}_{3}$ 幅偏差飞見られたスキッド マークの影響が活㹸消えており, 使用しない場合に 較べて効果の大をい事がわかる。
N. 結
言
鹿島熱延工場の $\mathrm{E}_{4}$ に

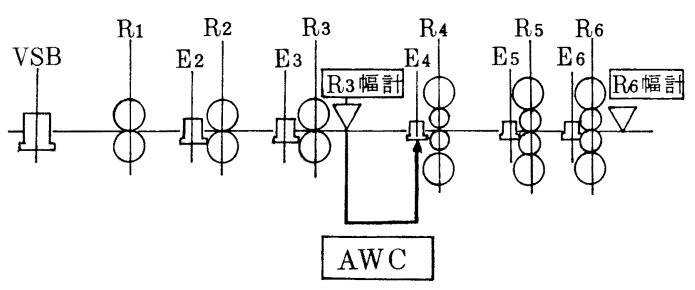

図 2 粗ロールレイアウト
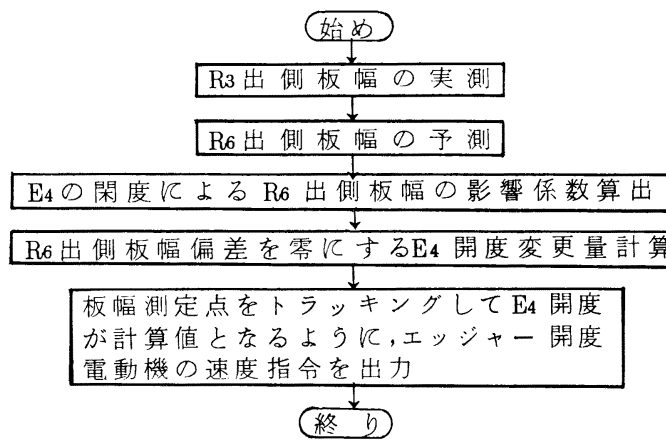

図 3 制御フロ一

おいて, 昭和 54 年 4 月より, 本格稼動した A C システムは, 以来安定して効果を発揮しており, 板 幅精度の向上,ひいては, トリム歩留の向上に大いに貢献している。

文献 1) 山口ら；第２９回塑性加工連合講演会論文集（１９７７８年１１月） 2)芝原ら; 同左 
(366) 621.771.237.016.2: 621.771.014.3: 621.771.073

' $80-\mathrm{S} 967$

ホットストリップ粗圧延におけるワークロールの負荷特性とロールの損耗

新日鐵 生産技術研究所 O大貫 輝, 蓮香 要, 加藤 治 工博中島浩衛

1. 緒 言 : 熱間圧延におけるワークロールの熱負荷とその損耗関係については既に高温摩耗試験実験と熱負 荷シミュレーション解析を行い, ロール材質特性に合せた圧延条件が選ばれねばならぬととを報告した(1) (2)。今 回は,ホットストリップ粗圧延で, 従来の連続圧延法 から 1 〜 スタンドによる高負荷リバース圧延法を探 用した場合のロールにかかる負荷と損耗について 2,3 の検討を行ったので報告する。

2. 高負荷リバース粗圧延のロール負荷検討：高負荷 粗圧延を行う場合, 先づロールの圧延接触弧面におけ る荷重分布とロール面の温度を使用ロール材許容限内 亿抑え, 且つ圧延材の噒込み性を損なわないような圧 下条件を探り, 更にバックアップロールとの接触応力 もワークロールの疲労損傷許容限内に入るよう考虑す る必要がある。

このような観点から粗 1 スタンドおよび 2 スタンド によるタンデムリバース圧延
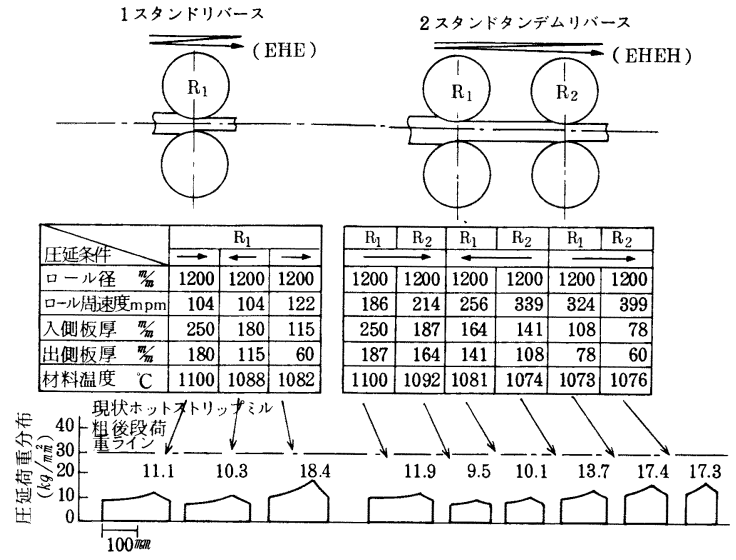

図1. 高負荷粗圧延条件とロールの死延荷重分布例 を行う場合などのロールにか かる諸負荷を検討すると図 1 〜3の如くなり, 噛込み性も 当社における実機の噒込み板 厚と圧下率の関係（図4)内 にはば入る条件に抑えること ができる。この場合, ロール 周速度の制限があるがいづれ も $\mathrm{Tafel}^{(4)}$ の噒込み角度から
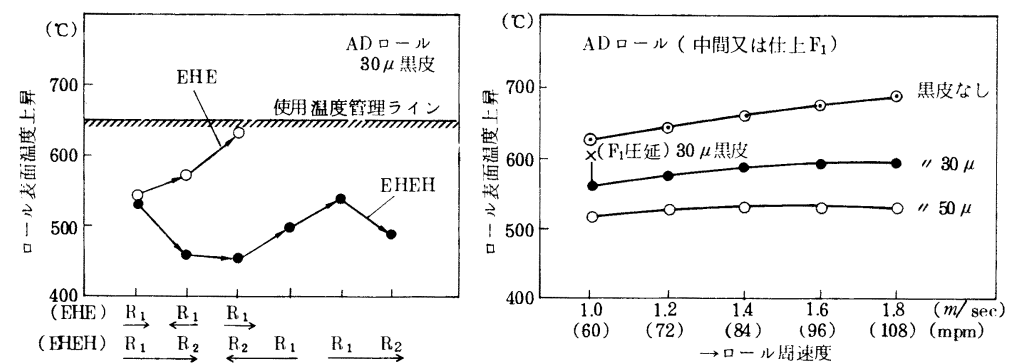

図 2. 粗高負荷リバース圧延におけるロール表面上昇温度シミュレーション(3) 決めるのがよい。

また，バックアップロー ルの接触応力の影響は使 用ロールの大径化で緩和 できるととが判った。

3. 結 言: 多スタン ドの連続圧延法から小ス タンドの高負荷リバース 圧延法に変える場合適切

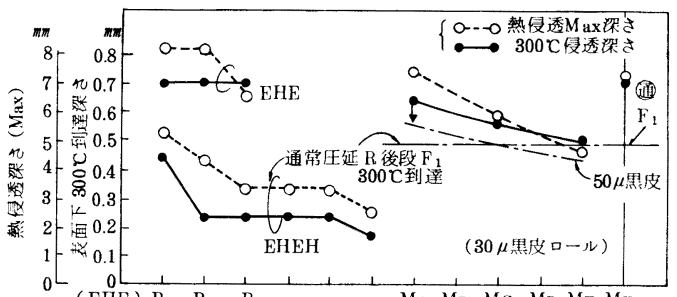

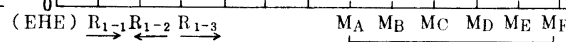

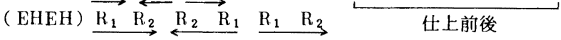

図3. 圧延条件とロール表層熱侵透深さの関係

な圧延条件を選べば，殆んど現用ロールの負荷許容限内に抑えることができる。

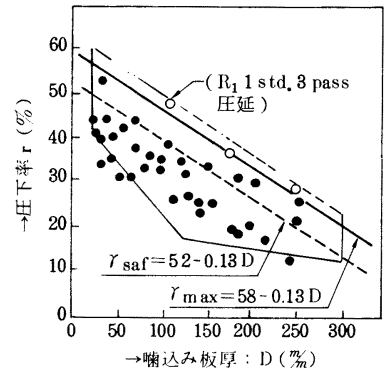

因4.現えルにおける嘴込み板厚 と下下率の関係
(1) 大貫はか, 鉄と鋼 65,11, S 789 ('79)
(2) 加藤ほか, 鉄と鋼 66,4, S 335 ('80)
(3) 松本はか, 第 29 回塑性加工連合講演会講演論文集 139
(4) W. Tafel etal. S.u. Eisen 44 (1924) S 305 309 
ホットコイルトップ部䭪楛込に対する最適負荷配分の研究

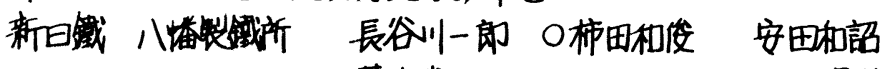

荒不省一田中正二江崎躇則

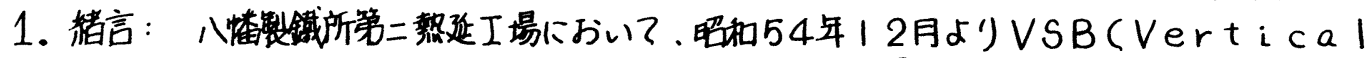
Scale Breaker)が榢傮を始めた。これにより同工埸における幅轧し能力は大幅に向上し たが，幅棈度の向上を目指す際にホットコイルトップ部の幅茖込が問題とすった。そこでこの対策とし て当VSBと既設工ッジャーとの絸合世を前提に、䭪洛边量を最小とする为の最速条件を見出すべく。 諸テストを通して検詂し操業標草化する事に成功したのでとの概要について郝告する。（図1.2参照

)

2. 実跧方法：实機を用いてVSB2/Pス 間の負荷配分・VSBKIッジャ一間の貝何配 分を变更し、ホットコイルトップ部の蕾灌边量 を比較した。このテストではVSB又はエッジ ャ一間の負荷配分を变化させてホットコイルト

ッつ部の幅溚边量を、エッジメーZ、VSBの 壬下量固定の条件の下て行む,ている。

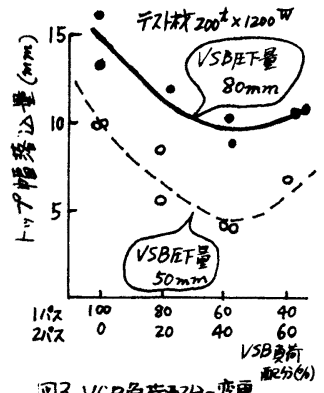

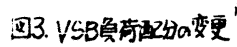

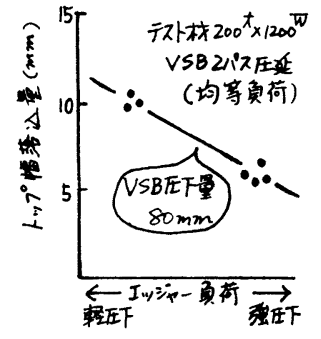

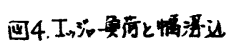

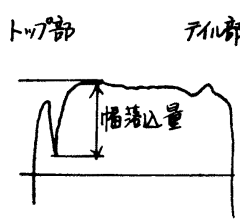

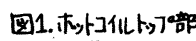

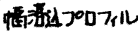

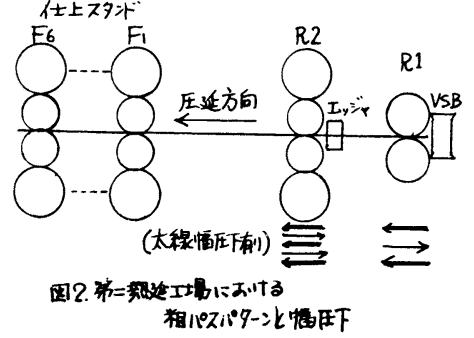

粗102ス

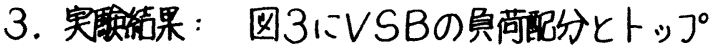
部愊洛边量の関係を示す。この結果から、119スと2 1゚ス目の蜔投し量をほぼ均等に設定する事によりトッ プ部の愊洛边量を最小化できる事の゙解った。次上通常 のVSB幅圧下条件である8 8 m (219人ト-タル : 均等悬荷)での工ッジャ一真荷とトップ部雷洛边量 の関係を图4に示す。これでわかる様に、VSB80 $m m$ 圧下の腸合、VSB均等員荷としエッジャ一强圧

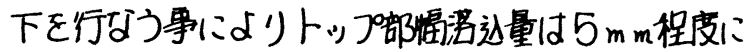

スラブ橎とコイル幅データよ川 幖任下必要量区算出する

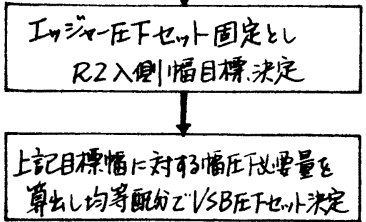

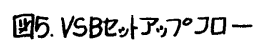

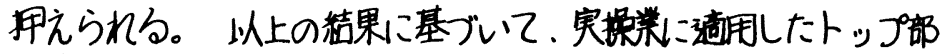
幅渚込量を最小化するた奻のVSB及びエッジメー設定法の概路を 四らに示す。すずスうブ幅・コイル幅のデータからトータル煏圧下 必要量を萛出する。さらに、コイル愊によってて定めたエッジャ一仕

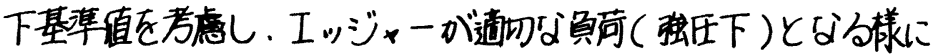

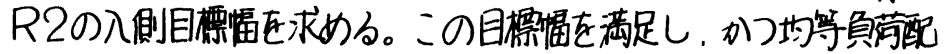

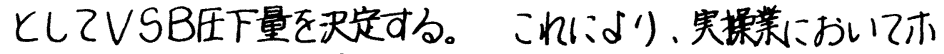

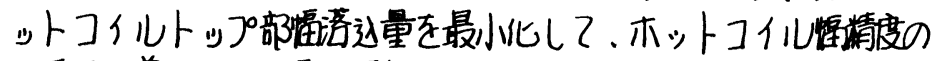
大愊る改善を行すう事が可能どった。

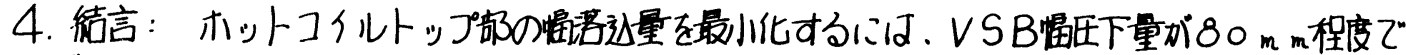

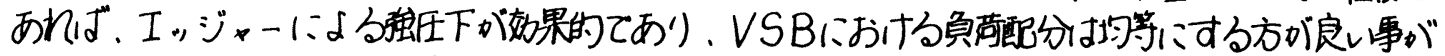

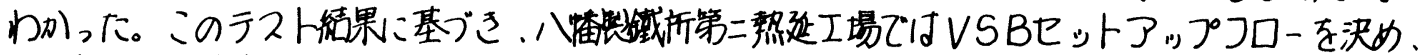
ホットコイル幅费込量の最小化に成功した。 
621.771 .237 .068

'80-S 969

\title{
（368） 油圧ラッパーロールによるストリップ段差回避制御システム
}

\author{
新日本製鐵株 \\ 石川島播磨重工侏
}

八幡製鐵所 $\bigcirc$ 柿田和俊城戸嗣郎

赤時惠

高橋則夫二反田正夫桑野博明

1. 緒 言 従来のホットストリップミルのダウンコイラーでは, ラッパーロールがストリップを押し付ける巻取 り初期の段階において種々の問題が生じていた。すなわち,ストリップ先端に 2 巻目以降のストリップが重なってできる段 差部がラッパーロールを跳ね上げ，その結果ラッパーロール，ストリップ間に過大な衝撃力が発生し，ストリップに先端傷 と称する傷が付いたり，ラッパーロール機械系が破損したりした。今回新日鐵八幡製鐵所で，コイル回転に同期して段差部 のみを回避してストリップを押し付ける新形式の油圧ラッパーロールのテストを行ない，実用化の目処が付いたので報告する。
2. 新形式油圧ラッパーロール制御システム
図 1 亿本システムの概要を

示す。ストリップの先端を追跡するトラッキング回路と油圧シリンダーを駆動する電 気・油圧サーボ系の 2 つ機能から構成されている。

(1) トラッキング回路

ピンチロールおよびラッパーロールに取り付けた加速度計と回転パルス発振器, なら びにそれらを取り込んで演算を行ならェレクトロニクス回路より構成される。ピンチ ロールヘ取り付けを加速度計の出力信号のレベル変化からストリップ先端進入を知り, ピンチロール回転パルスをカウントするととにより先端を追跡する。ラッパーロール 八取り付けた加速度計で再度先端位置を確認し, 以降はマンドレルの回転パルスで 追跡する。

(2) 電気・油圧サーボ系

ラッパーロールを開閉する油圧シリンダーは高応答の電気・油圧サーボ弁で駆動さ れる。本制御采はコイル 1 回転ごとにトラッキング回路からの信号を受けて, 位置 制御モードルよりストリップ段差部を回避した後，押し力制御モード によりストリップをマンドレルに押し付ける。そのため, ラッパーロ ールの位置を知る変位計, シリンダーに取り付けた圧力変換器, なら びにサーボ・アンプ，比較加算演算器等より構成されている。位置制 御の応答例在図 2 亿示すが, 設定值に质深 $50 \mathrm{msec}$ で達しており, 所定の応答が得られている。

\section{3. 実機巻き取り結果}

図 3 亿本制御システムによりストリップを巻を取った結果を, 図 4 に 従来のエアーシリンダー押し付けによる巻を取り結果を示す。アーム に発生する加速度は $7 \mathrm{G}$ から $2.3 \mathrm{G}$ へと低减し, ロールの跳ね上がり るほ深なくなっている。

4. 結言電気・油厈サーボ采で駆動される油圧シリンダ 一でラッパーロールを制御するてとにより，ストリップ段差の回避制 御が可能となった。

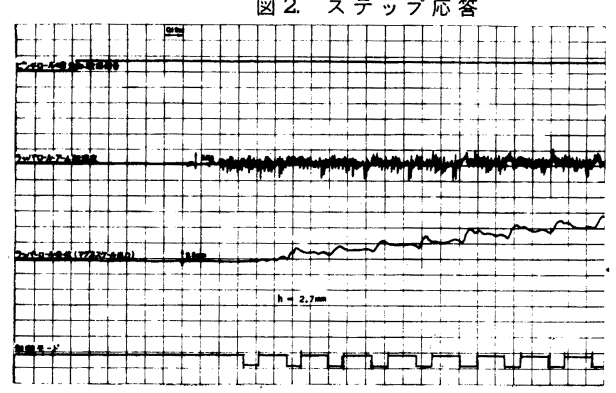

図 3. 実巻き取り時実測チャート(制御あり)

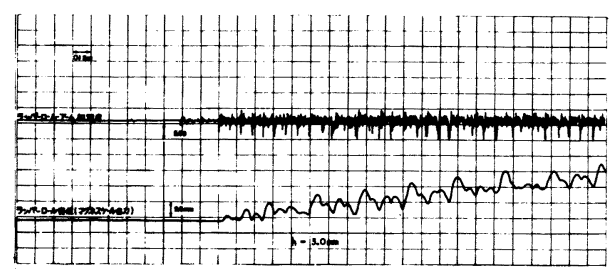

図 4. 実巻き取り時実測チャート(制御なし) 


\section{1. 緒言}

ホットストリップ幅圧下压延における大をな問題点の一つに，フイッシュテール状クロップの発生による歩留 低下がある。そこで，てのクロップを減少もしくは矩形化するととにょり歩留低下を防止するクロップ制御法に つレて,プラスチシンモデル実験により種々比較検討した。

\section{2. 各種クロップ制御法}

図 1 亿，幅圧下压延におけるフイッシュテール状クロップの生成機構を示す。幅 压下匠延では，素材の板幅比 $\mathrm{W}_{0} / \mathrm{H}_{0}$ が大をくエッジ部のみが局部圧下を受け，材料 中央部反比べエッジ部の伸びが大をくなりフイッシュテール状のクロップが生じる。 従っててのクロップを制卸するには，(1)中央部の延伸を大をくする。(2)エッジ部の

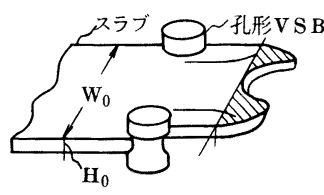

図1.クロップ生成機構 延伸を小さくする 2 つの方法があり，(1)の方法は压延の機構上 困難で(2)の方法が実現性が高いと考えられる。表 1 亿，(2)の考 乞方に基づく各種クロップ制御法を示す。A，B法は機械切削 または切断によるメ'タルの除法, 帛) 2 法はプレス加工による予成 形，D，E法は圧延におけるメタルフローの拘束を特徽として いる。

\section{3. 各種クロップ制御法の比較}

モデルは実機の $1 / 10$ 相当で, 材料寸法は $28_{\mathrm{mm}}^{\mathrm{H}} \times 190 \stackrel{\mathrm{mm}}{\mathrm{W}_{0}}$ $\times 3000_{m m}^{\mathrm{L}_{0}}$ である。V S B 孔型堅ロールの溝底径および水平ロ一 ル径は $120_{m m}^{\phi}$, バススケジュールは $\mathrm{V}_{1}-\mathrm{H}_{1}-\mathrm{V}_{2}-\mathrm{V}_{3}-\mathrm{H}_{2}-\mathrm{V}_{4}$ $-\mathrm{V}_{5}-\mathrm{H}_{3}\left(\Delta \mathrm{h}_{\mathrm{v}}=15 \mathrm{~mm} /\right.$ バス, $\left.\Delta \mathrm{h}_{\mathrm{H}}=0\right)$ で幅圧下を行なった後 $\mathrm{R}_{2}$ 最終厚み相当むで圧延した。実駼は各方法とも条件を種々 変更して行なったが，図2亿その内最も効果の大をなるのを通 常法と比較して示している。

平均クロップ長さ $\mathrm{C}(\mathrm{T}+\mathrm{B}) / 2$ の隇少効果は, 一般に $\mathrm{B}, \mathrm{C}$ 法が最も大をく, トータルクロップ重量 $\mathrm{W}_{\mathrm{CT}}$ でも B， C 法が最 少となるが，歩留低下代 $\triangle \mathrm{Y}$ は B 法が予めメタルを除去している ためC法が最小になる。なお， C法では切断あるいは連続スラ ブを用いても効果は潘济同じであり，E法にも相当のクロップ 滅少効果のあるととが認䟡れる。

\section{4. 結言}

プラスチシンモデルねより, 各種クロップ制御法を比較した 結果, 総合的にみてプレス予成形法が最も効果的であるとの結 論を得た。今後本法について更に詳細に検討を進めて行く。 参考文献

1）中川吉左衛門, 他：川鉄特許, 特開昭 55-10363

2）樽井, 他：昭和 55 年度春季塑性加工講演会論文集, P $41 \sim 44$

3）侍留, 他： , P $45 \sim 48$

表 1. 各種クロップ制御法

\begin{tabular}{|c|c|c|c|}
\hline 兮法 & 徵 & 考 & 参考圈 \\
\hline A & $\begin{array}{l}\text { スラブの } \\
\text { コーナカッ }\end{array}$ & $\begin{array}{l}\text { ·メタルロス } \\
\text { ·面取り加工 }\end{array}$ & $\left.x\right|_{-\mathrm{W}_{0}} ^{\mathrm{H}_{0}}$ \\
\hline B & $\begin{array}{r}\text { スラブTop } \\
\text { Bot } \\
\text { 端面カット } \\
\end{array}$ & $\begin{array}{l}\text { ·×タルロス } \\
\text { ·切断加工 }\end{array}$ & \\
\hline $\mathrm{C}$ & $\begin{array}{l}\text { スラブ先後端 } \\
\text { プレス予成形 }\end{array}$ & $\begin{array}{l}\text { ·メタルロスなし } \\
\text { ·ブレス加I }\end{array}$ & \\
\hline D & $\begin{array}{l}\text { プッシャー } \\
\text { 押込み圧延 }\end{array}$ & $\begin{array}{l}\text { ·メタルロスなし } \\
\text { ·プシー・押込 })\end{array}$ & $\mathrm{P}_{\mathrm{p}} \leftrightharpoons$ \\
\hline $\mathrm{E}$ & $\begin{array}{l}\text { VSB片パス } \\
\text { 压延 }\end{array}$ & $\begin{array}{l}\text { ・メタルロスなし } \\
\text { · (能率, 庛) }\end{array}$ & 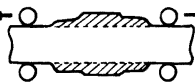 \\
\hline
\end{tabular}

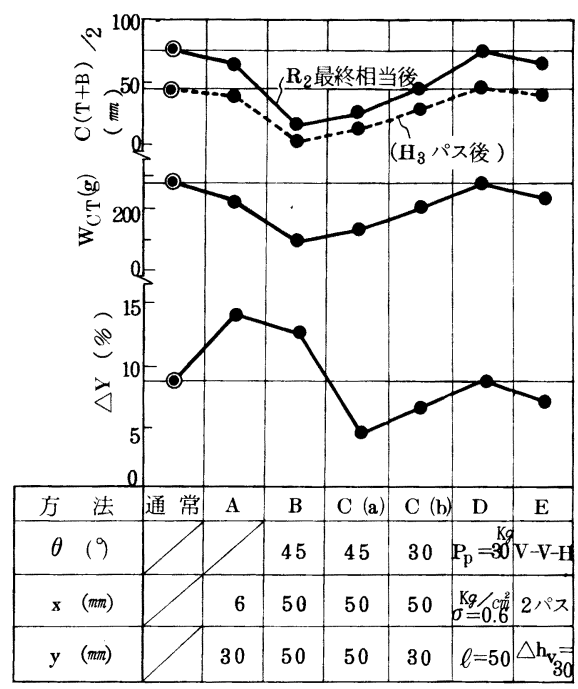

図2.クロップ制御法の比較 
1. 緒言熱延鋼板の压延トップ及びボトムで生じるクロップの切捨ロスは、圧延歩留り上重要な問 題の一つである。压延過程でクロップ切捨ロスを減少させる為には、異形クロップの生じない圧延制御 方法の確立と、生じたクロップの最適切断方法の確立が不可欠であり、その為にはクロップ形状の定量 的把握が必要である。乙の為、压延ラインにクロップ形状計測装置を導入し、オンライン化の目途を得 たので報告する。

2. クロップ形状計測方法 Fig. 1亿機器構成概略図を示す。青色域にピーク感度を持つ光学フィル 夕及び T Vカメラと、青色域に高い光エネルギを有するキセ)ン管を用いたパワーストロボ（閃光時間

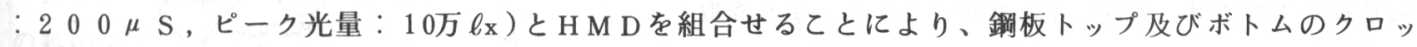
プ像をとらえる。閃光時間の非常に短いストロボを用いることにょり、高速移動する赤熱鋼板を静止像 としてとらえ、画面内での材料のブレ等 の誤差を少なくした。また、シャッター、 回転体等のメカニカルな機構は全くなく、 メンテナンス上非常に有利である。

得られた画像は画像処理装置により、 2 值化、エッジ部の 2 次元座標算出等の 処理後コンピューターに取り込まれる。 コンピューター内では、最適切断位置の 算出、F F T (高速フーリェ変換) を用 いた形状係数等の算出が行われる。ク口

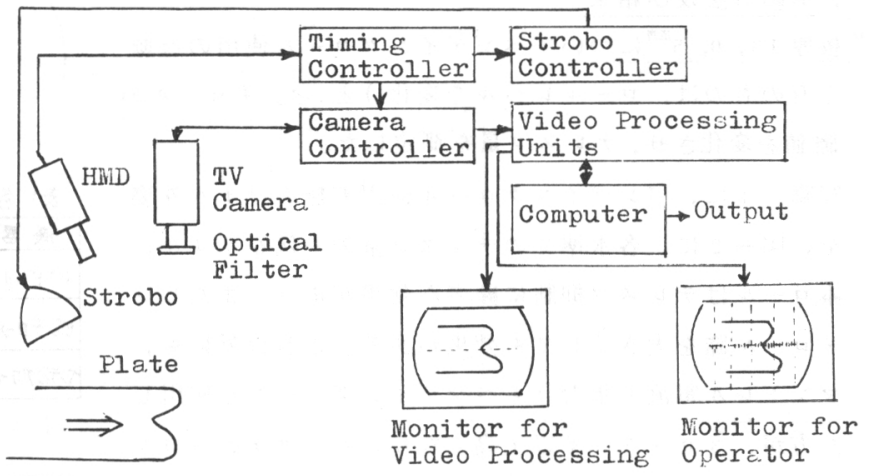
ップ形状の定量的把握は、形状係数の統 計的処理により行われる。

Fig. 1 Schematic drawing of crop-shape measuring system.

3. 計測結果 Fig. 2 に鋼板トップの 2 值化モニター像とコンピューター取込み後の生データ出力例 比較を示す（ 1 : 立上り， ゆ：立下り)。プリンタ 1 行に走查線 4 本分、かつ水平方向には $1 / 4$ に圧縮し て出力した。画像処理の過程では、ウィンドウ区間を設け不必要な区間での座標算出は行わない様にし ている。Fig. 3 にての後の処理概略を示す。
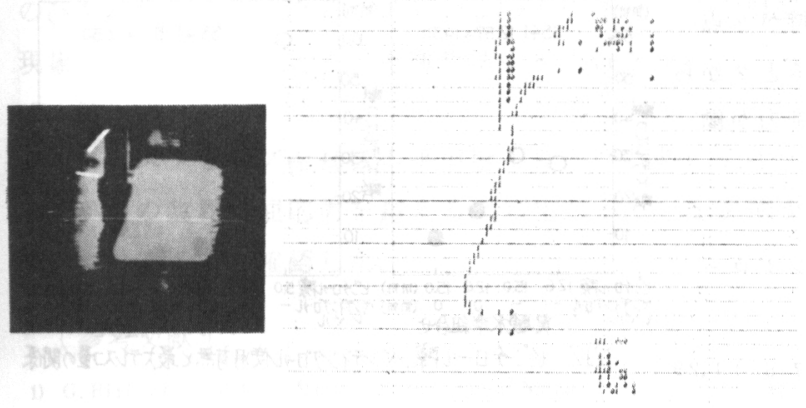

Fig. 2 Comparison of level sliced image and its printed out data.

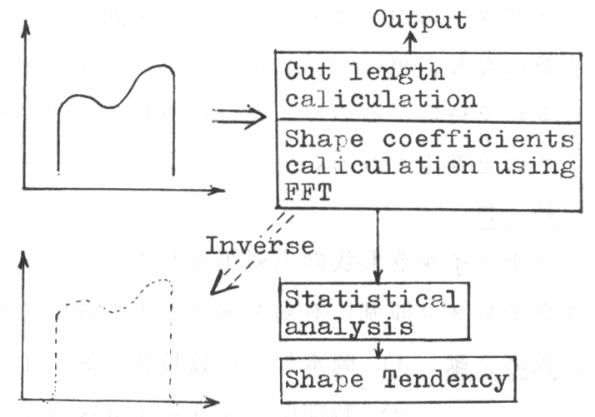

Fig. 3 Schematic diagram of caliculating flow 


\section{（371）厚物ホットコイルの巻形状におよほすずンデイングロールの効果}

川崎製鉄㭑身製鉄所 三宅祐史 滝沢昇一。小西敏弘

池永孝雄 板谷進 前坦謙一

1. 緒言 当所 熱延工場の厚物用巻取機は上ピンチロールの直前にベンディングロールを設置し外巻部の巻 ゆるみ防止に効果を発揮している。本口ールは, これ以外にも熱間降伏点の高い厚中板を巻取る際に発生し やすい, 中間から外巻部のテレスコ (耳不揃) 防止にも大きく寄与しているのでここに報告する。

2 . 設備の概要

図ー1に，厚物コイラーのピンチロールとベンディング ロールの配置を, また表一 1 にその仕様を示す。 ベンディングロールはストリップの先端がピンチロール 啮込後に下降させ, 巻取完了迄押付けている。また巻取 寸法に応じてロールレベルを調整できるようにしている。 3 . 実験方法及び結果

板厚 $13 ， 9 ５^{m m}$ についてベンディングロール使用の有無 （有のものは, ロールレベルを変化）と,ビンチロールの 障值を変化させ，テレスコ量を測定した。

写真 1 に, ベンディングロール使用有無のコイル巻姿 を, 四一 2 に, 各水準でのテレスコ量の一例を示すが, 本ロールはテレスコ抑制に顕者な效果があり，またピン チロール隚を大きくしても效果がある。これ以外にも， マンドレル電流（張力）もべンディングロールを使用し た方が， $30 \sim 50 \%$ 以上高くなり，バックテンション 機能も十分果している。

\section{4. 考察}

降伏点の高い厚中板は, 上下ピンチロールのオフセット $\left(20^{\circ}\right)$ のため, マンドレル巻付後にピンチロール直前 で浮き上がり，これがストリップ鋼板の蛇行を誘発し， テレスコを発生させるものと考えられている。

今回の結果からピンチロール隙を板厚より大きくすると ストリップに対し上下ピンチロール間の 1 点支持が 2 点 支持になり，更にベンディングロールを使用すると 2 から ら 3 点支持になるので, 蛇行に対して大きな抑制力が働 くものと推定される。

\section{5 . 結 言}

ホットコイル巻形状向上対策として, ベンディングロー ルがテレスコ抑制に有効であるととを確認した。

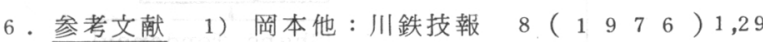

2) 特開昭 $4 \begin{array}{llllll}4 & 9 & -1 & 0 & 8 & 5\end{array} 2$

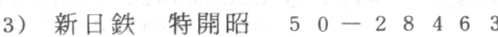

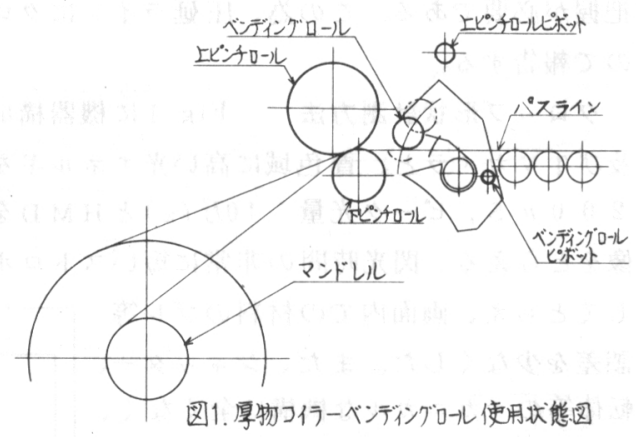

表1. 各楼照仕栚

\begin{tabular}{|c|c|c|c|c|}
\hline 機 替 & モータ仜栚 & 押付力 & 口一几寸寸法 & 位㯰钓卸䡉佣 \\
\hline マンドレル & $\begin{array}{l}2-D C 500 \mathrm{~kW} \\
380 / 1185 \mathrm{rpm}\end{array}$ & - & 一 & - \\
\hline ピ:チロ $\rightarrow ル$ & $\begin{array}{l}\text { LF } \\
\text { DC } 40 \text { OKW } 800 \mathrm{~m} \%\end{array}$ & ${ }^{\text {最大 }}{ }_{52}^{\mathrm{t}}$ & $\begin{array}{l}=920^{\phi} \times 2300^{l} \\
F 520^{\phi} \times 2300^{l}\end{array}$ & 人정 $0 u+36$ \\
\hline 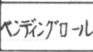 & DC104KW $1100 \mathrm{rpm}$ & 最大 $20^{t}$ & $350^{\phi} \times 2300$ & \\
\hline
\end{tabular}

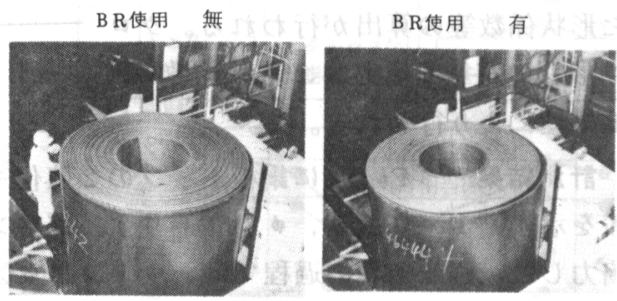

写真 1 コイル巻姿の比較

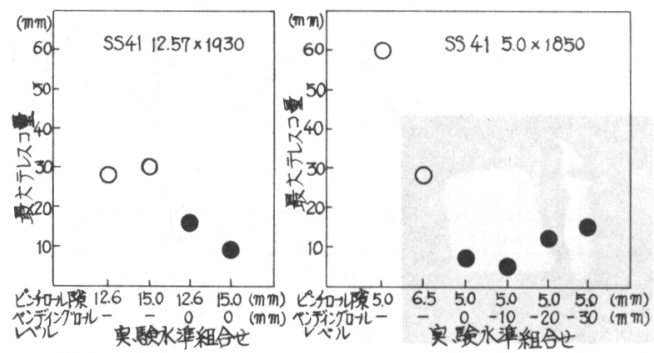

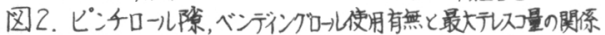




\section{(372) $)^{669.14-122.4-415: 531.717 .8: 539.377}$}

( 鋼材冷却時の熱応力解析 第 1 報)

川崎製鉄株) 技術研究所门吉田博, 佐々木徹

工博 田中智夫

\section{1. 緒 言}

ホットストリップでは，仕上圧延機出側から巻を取りまでの形状が平坦であっても次工程のスキンパ スミルの入側で平坦度不良（通常は耳のび）を発生するととがあり，スキンパス能率を阻害している。 また，乙れを防止しないと仕上圧延におけるベンダー等による平坦度制御は意味がないてとになる。本 報はこの平坦度不良が仕上圧延後に生じる熱応力と関係があると考え, 変態を考慮した鋼板の熱応力支 計算により求め,熱応力が平坦度不良発生に及济す影響を明らかにした。

\section{2. 解析手法}

長手方向（L方向）の熱流は無視でをるとして 2 次元のFourier の熱伝導方程式（発熱項を含む）を導を，乙れをI A D 法と呼ばれ る特殊な差分法を用いて断面内の温度分布を求めた。熱庆力計算は L方向のみを考え，C断面は平面を保持するといら仮定を設けた。 ただし, 計算に必要な物性值 (比熱, 熱伝導度, 熱膨張係数, 降伏 応力など) は温度だけでなく変態相分率の関数であるため変態量の 計算も温度計算と同時に行った。むた, 平坦度の良, 不良は圧縮熱 応力と板の臨界座届応力との比較により判定した。

\section{3. 計算結果}

川鉄水島製鉄所のホットストリップ工場における冷却設備を想定 し, 冷却後の耳のび不良在起こしやすい板厚 $3.24 \mathrm{~mm}$, 板幅 $2173 \mathrm{~mm}$ 薄物広幅材 $\left(0.14 \%{ }^{\circ} \mathrm{C}, 0.05 \% \mathrm{~S} \mathrm{i}, 0.90 \% \mathrm{Mn}\right)$ について種々の冷 却条件で計算を行った。その一例を図 1 , 図 2 亿示す。図より幅端 部 (耳部) と幅中央部とでは温度, 熱応力, 変態相分率の経時変化 が異なり，その結果として室温における熱応力（残留応力）は耳部 (約 $200 \mathrm{~mm}$ ) で圧縮, その他で引張りになっているのがわかる。種 々の条件で計算した結果, 仕上圧延直後の幅方向温度分布（耳部で 温度が低い) が大をく, 泠却が幅方向不均一(耳部で泠却が速い) で, 巻を取り温度が低いものほど耳部の圧樎応力は大をくなり，耳 のびを発生しやすくなるととがわかった。また，乙の計算結果は実 現象とよく一致して和り, 本解析法の妥当性在示している。

\section{4. 結 言}

ホットストリップ冷却後の平坦度不良が泠却時に発生する压縮熱 応力が板の臨界座屈応力を越えるため生じることを変態を考慮した 熱応力計算により確認した。

( 参考文献)

1) G.Birkhoff and R.S.Varga:Trans.Amer.Math.Soc., 92 (1959), 13

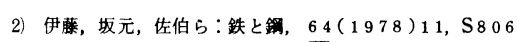
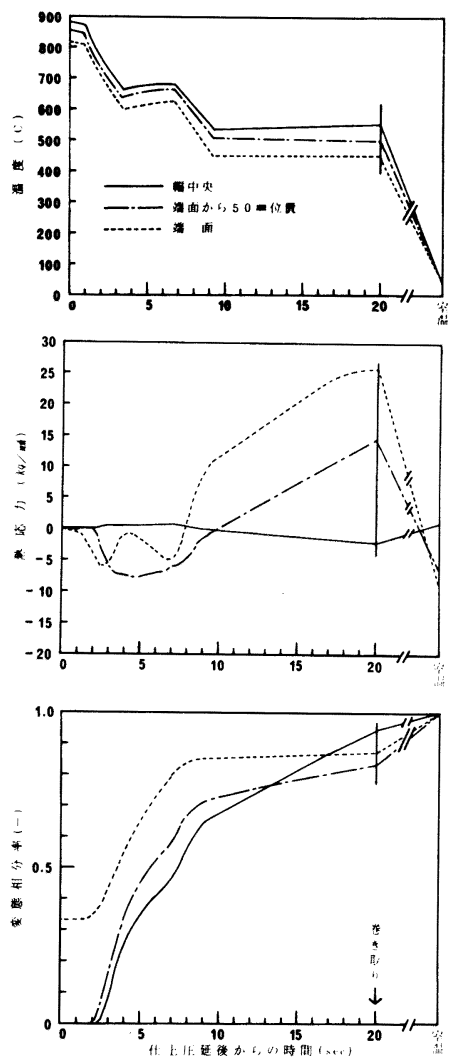

図 1. 温度, 熱応力, 変態相分率 の経時変化

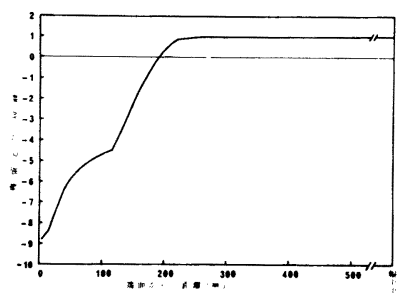

図2. 残留応力の幅方向分布 


\section{（373） スプレー冷却法による走行している鋼材の冷却}

千葉製鉄所 北川正樹 中沢正敏

\section{1 緒言}

知多製造所 唐沢順市

唋材を高温から水冷する時の冷却能は定式化 ${ }^{1)}$ されているが、龬材の冷却速度に及ぼす水冷中の表面 スケールのはく﨎性、各種冷却ノズルによる巾方向水量密度の差異、および噴射後鋼材表面に沿う水量 の影響等については明確ではない。本研究では、てれらの点を明らかにし、定量化を行った。

\section{2 実験方法}

$600^{l} \times 200^{\mathrm{w}} \times 25.4^{\mathrm{t}}$ の普通炭素鋼板を $1000^{\circ} \mathrm{C}$ 加熱後、 移動可能な冷却床に設置し水平に走行させながら、上下のノ ズル群より冷却水を斜めに噴射して冷却した。測温位置は全 て板厚中央部である。

\section{3 実験結果}

（1）スケールの影響噴射される泠却水によるスケール のはく離が十分でない場合には、冷却能が低下し、かつ残存 スケールの厚さが厚い程冷却能は小さい。

（2）噴射圧力の影響圧力が高くなるとスケー ルのはく離性は良くなるが、 $4 \mathrm{~kg} / \mathrm{cm}$ 以上の圧力では 反射水量が増えて板面に沿う水量が減少するために 冷却能は低下する。

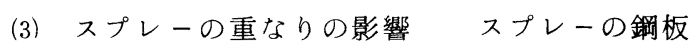
衝突位置における、隣接するスプレーの重なり比の 冷却速度に及ぽす影響を図 1 に示す。スプレーは放 射状に広がるため、衝突線から遠ざかるにつれて中 心部の水量は低下する。従って、スプレー中心部の 冷却速度は重なり部のそれよりも小さく、板表面に 沿う水流の冷却効果が大きいととを示している。

（4）走行速度の影響走行速度と冷却速度の関 係を図 2 に示す。走行速度 $500 \mathrm{~mm} / \mathrm{min}$ 以上では、 冷却速度は漸減する。

（5）冷却能の定式化今までに得られている水 量密度と冷却速度の関係 ${ }^{1)}$ を用い、実測の冷却曲線 より算出した鋼材表面の水量密度（有効水量密度） の長手方向変化を図 3 亿示す。同一水量の場合には 有効水量密度は走行速度によらず、長手方向のみの 関数として表わせる。

参考文献 1）日本鉄鋼協会 熱経済技術部会鋼 材強制冷却小委員会：銅材の強制冷却；1978年11月

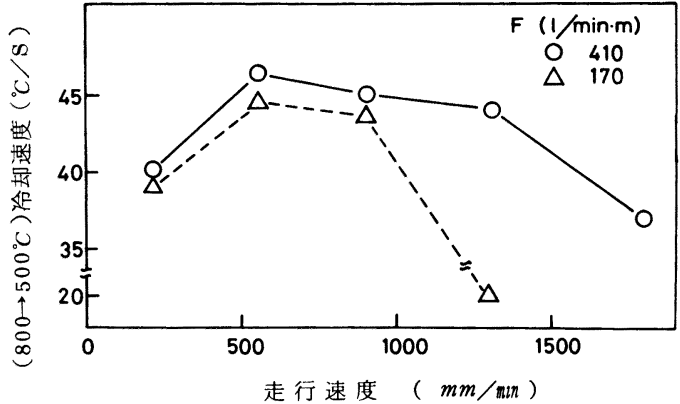

四 2 走行速度と冷却速度の関係

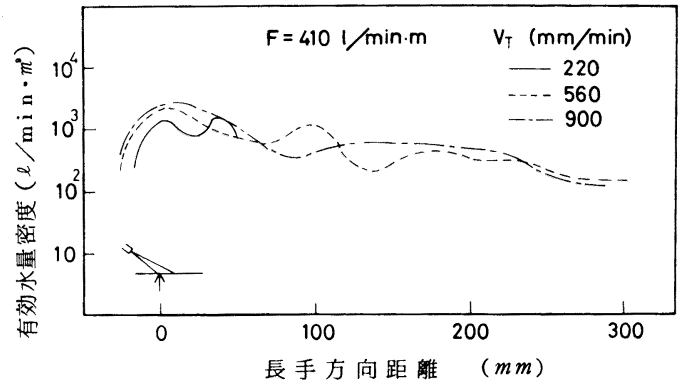

図3 有効水量密度の長手方向変化 
(374) $\mathrm{CO}_{2}$ (

光製鐵所松野弘

新日本製鐵湖基礎研究所南田勝宏, 山口重裕 生産技術研究所兽 我弘
1. 緒 言

レーザによる切断は、困1の如く種々の要因の影響を受 ける。その定量的な把握は鉄鋼業におりる鋼板の切断とい う面から特に重要と考えられる。前報では常温での切断加

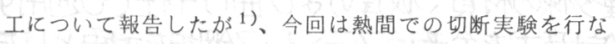
い、加熱温度の影響について $2 ， 3$ の知見を得たので報告 する。

2. 実験方法

目2 亿実験方法の概略を示す。レーザビームは焦点距離 150 mのレンズにより試料表面上に集光する。試験片 ( S US 304 , 厚み： 5 及び 10 m ）を哣で $400^{\circ} \mathrm{C}$ まな $800{ }^{\circ} \mathrm{C}$ に30分間加熱保定した後、直ちに移動テーブル上にセット し所定のレーザ出力と切断速度で切断可否をチェックする。 この実験を絽り返すととによって、切断可能限界線を求 める。

尚アシストガスには $\mathrm{O}_{2} を$ 用いた。

\section{3. 実験結果および考察}

困 3 , 函 4 亿実験結果(限界切断速度曲線) を示す。

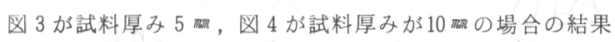
である。

一般にレーザによる鋼板の切断は、レーザ光による鋼板 の加熱溶融, 蒸発現象と鉄と $\mathrm{O}_{2}$ ガスとの酸化発熱による鉄 の溶虽現象とによって進行する。従って予め鋼板を加熱し ておけば、そのふん切断が容易に行なわれると予測される。 しかし、図3，4の結果によれば、単に鋼板の温度を上 げただけではかえって切断能力が劣化する場合のあるとと を示しており、これは極めて興味深い結果である。図 5 は この結果を概念的化説明したものである。すなわち試料が 高温になると、試料表面近くで酸化反応が起き易くなり、 さらに酸化反応は試料面内に拡大して、常温での切断とは その様相かかなり異なってくる。

写真 1 亿切断部の形状を示す。

\section{4. 結 論}

(1) 試料の温度が高温になると、切断能力が低下し、切 断巾も広く、切断面も極端にきたなくなる場合がある。

(2) 補助ガスに不活性ガスを使用するか、O する場合であ噴射法をエ夫したり、またはビームの集光条 件を変える必要がある。

1) 松野, 南田：鉄と鋼 66(1980) S 320
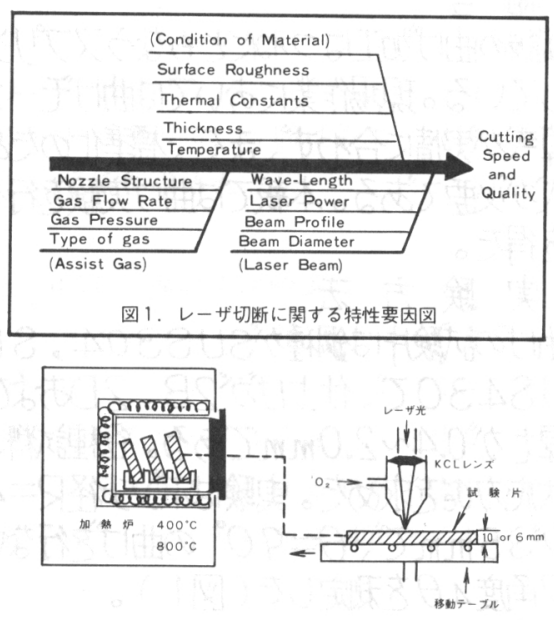

図2. 実験装置概略

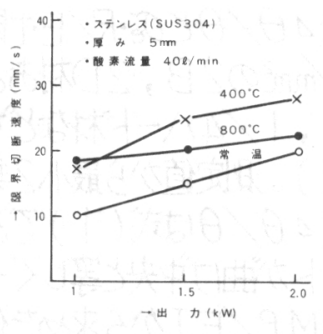

図3. 高温切断実験 (厚さ $5 \mathrm{~mm}$ )

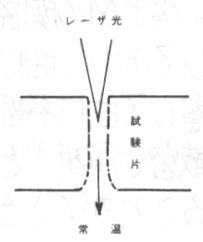

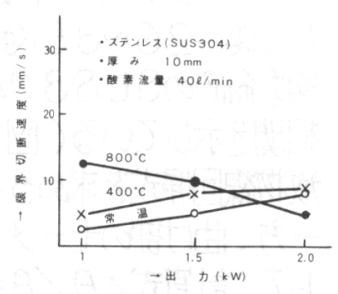

図4. 高温切断実験 (厚さ10mm)

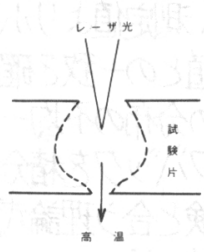

図5. 高温における切断概念図

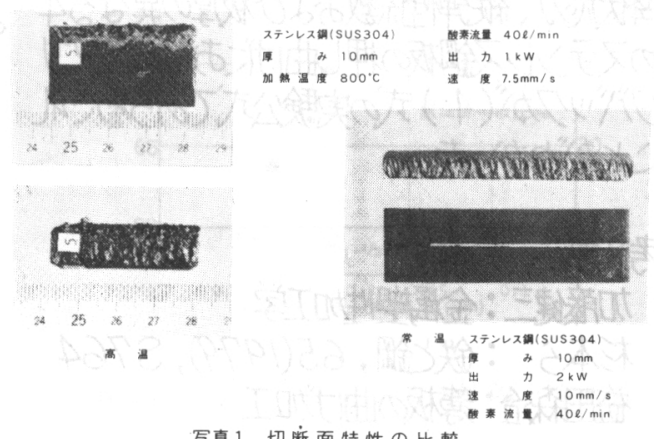




\section{I 緒 言}

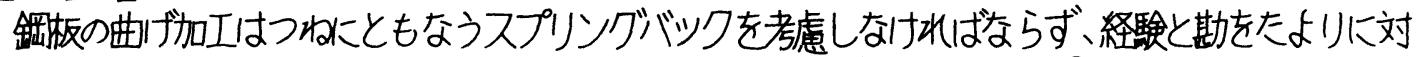

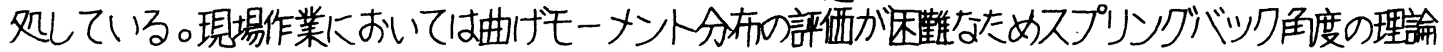

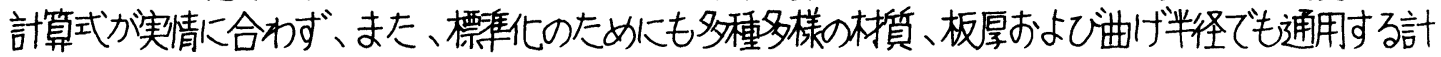

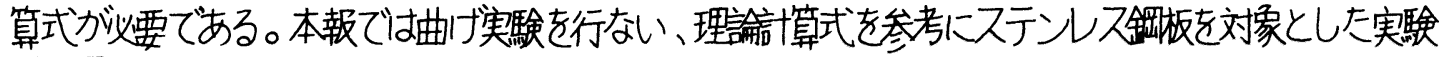
式考得た。

I实験方去

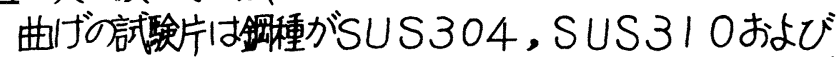
SUS430で、仕上げが2B，2Dおよびリ/4ハードで、 板厚七が0.4 2.0mmである。各種試料年とに引張試験で

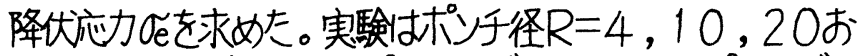
$よ ひ ゙ 35 m$ mで、 $\theta=90^{\circ}$ の曲げを行交い、スプソンヷバ ツク触 $\Delta \theta$ を矵定した(图1)。

III結果

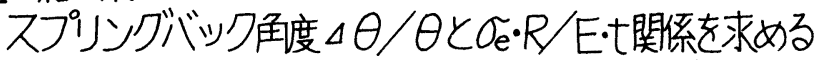
と、 $\widetilde{e}=26 \sim 35 \mathrm{kgf} / \mathrm{mm}^{2}$ の $2 B, 2 D$ 林およびのe $=72$ $\mathrm{kgf} / \mathrm{mm}^{2}$ のSUS304，1/4八ート㭕どすべてがよい 相関を示している(四2)。測定值から最小2乗近似人より

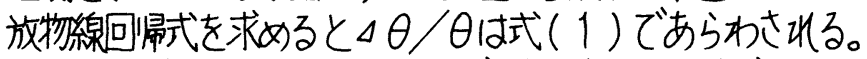
一方、曲掊のモーメントが曲げ中央と等しくー粎であると Uて、計算式 $\Delta \theta / \theta=M \rho / E I$ 分求陡值を四 2 に示 すが、㵋定値より小さい。竹とMの関係人ついては理論值と

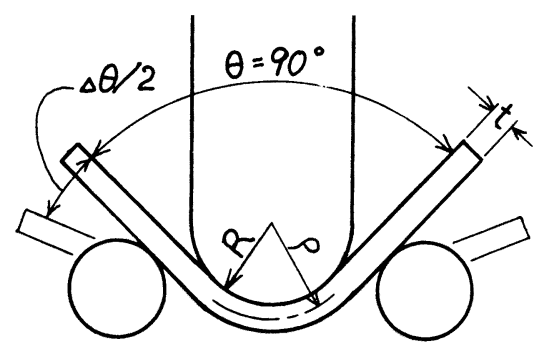

図1.曲け揍験の図 実験值との一致を確認)しており、曲げモーメ ントの分布の不均一を考慮して曲拉部のスプ リンヷバッワを皘分する厳密夻解析引を行なえ は美験と合う理論式を得ることができると思う。 疋結 論

降优标力、継弹性系数およ乙板桪の異なる4

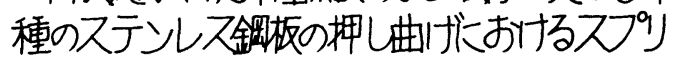
ングバッワが( 1 )式の実験公式であられされ るとがかかった。

\section{参考文献}

1) 加藤建三：金属勧性加工学

2) 杉本与:鉄と鋼, 65(1979), S764

3) 益田森治: 薄板の曲げ加工

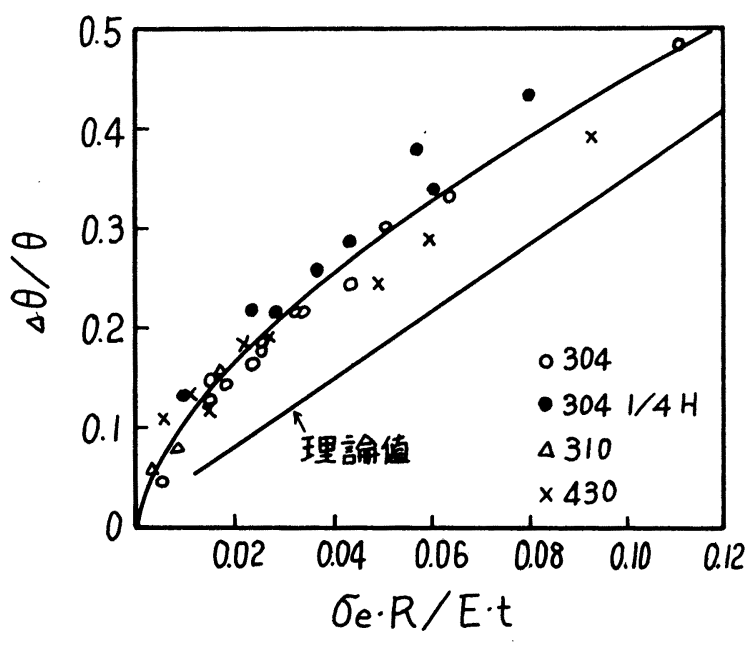

図2. $\Delta \theta / \theta と \sigma \cdot R / E \cdot$ tの関係 


\section{I . 緒 $\overrightarrow{\overline{⿳ 亠 口 冋}}$}

冷間鍛造に使用される材料の重要な特性として変形能がある。変形能は材料が破壊することなく变形 し得る能力を示すもので, 材質的要因と加工形態とに, 強く影響される。フェライト・パーライト組織 における鍛造割れは, パーライト部の破壊に起因するとの説もあるので, 今回は最も一般的な加工形態 である。据込加工におりる変形能とパーライト組織因子との関係を求めた。

II. 実験方法

低周波誘導炉で大気中溶製した $0.7 \mathrm{C}-0.9 \mathrm{~S} \mathrm{i}-0.99 \mathrm{Mn}-0.5 \mathrm{Cr}$ 鋼の $11 \mathrm{~mm} \phi$ 線材を用い, パテンティ ング条件をかえるととによって,オーステナイト粒径, パーライトコロニー径, パーライトラメラ間隔 を変化させ，それらについて据込割れ発生限界圧縮率を求めた。パテンティングにおいては供試材の中 心部に熱電対を插入してパーライト変態温度を測定し, 同一温度でパーライトを生成させた。変形能と して, 平滑円筒試験片による据込压縮試験と, 開口角 $30^{\circ}$, 切欠深さ $0.8 \mathrm{~mm}$, 切欠曲率半径 $0.15 \mathrm{~mm}$ の V 溝 付円筒試験片を用いて, 同心円溝付圧縮板による拘束圧縮試験を行い, 割れ発生率50\%における压縮率 を割れ発生限界圧縮率として求めた。

III. 結 果

(1) パーライトの限界圧縮率は絞り值の高い方が高くなる傾向があるが，かなりバラッキが大きく， パ ーライトの据込の変形能は一律に絞り值だけでは論じられない。

(2) パーライト組織の絞り值は，旧オーステナイト粒径の小さい方が高くなり，パーライトラメラ間隔 の小さい方が高くなる。

(3) 旧オーステナイト粒径が小さいと絞り值が高くなるにもかかわらず, 据込割れ発生限界圧縮率は, 旧オーステナイト粒径にあまり強く依存しない(第 1 図）。

(4) 据込割れ発生限界压縮率はラメラ間隔に強く依存し、ラメラ間隔の小さいほど絞り值と同時に据込 割れ発生限界压縮率が顥著に高くなる( 第 2 図)。

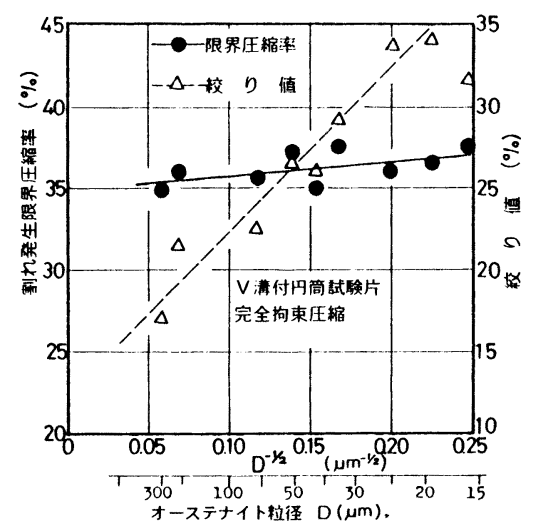

第 1 図オーステナイト粒径と変形能

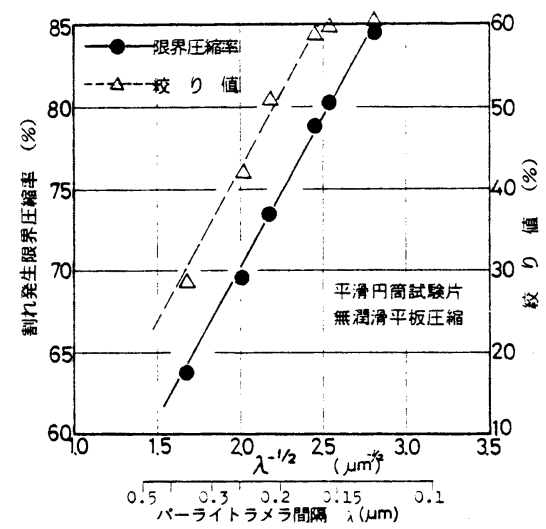

第 2 図パーライトラメラ間隔と変形能 


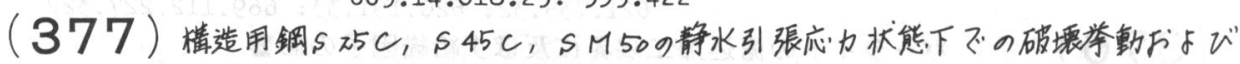
破墂举動四

東北大学金属材料研究所。斎滕栄志村宗昭

田中英八郎

工, 绪言静水引張㐫力状態下飞゙の金属材料の破堙举動を調べる:とけ棈造物の破堙古題を検計する

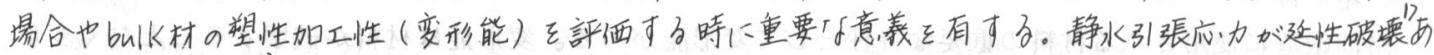

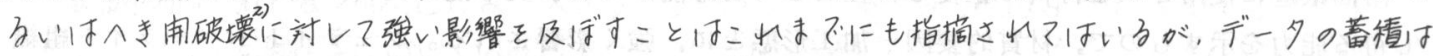

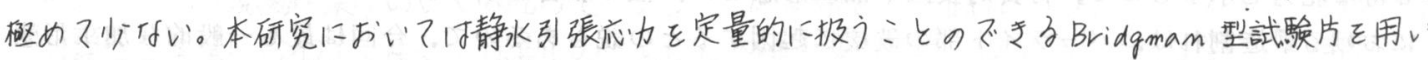

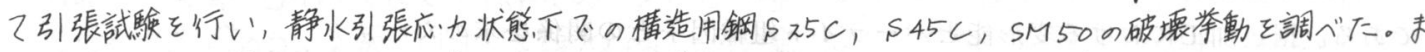

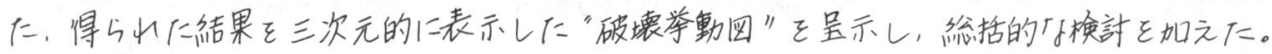

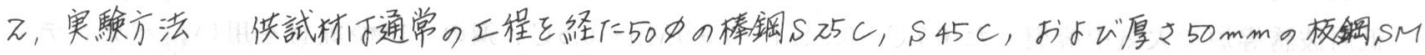

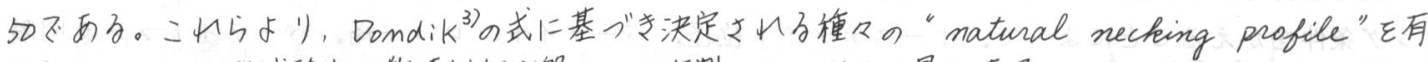
才るBridgman 型試験片を数值制御旋盤により作製した。才法撮小直径( ( a )

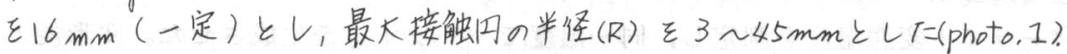
インストロン型試験機を用い, クロスヘッド速度 $0.5 \mathrm{~mm} / \mathrm{m}$ 涭不引張試験そ行

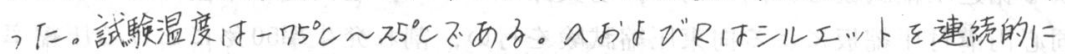

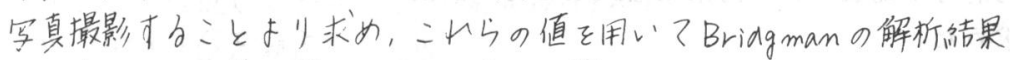

( (1)式了により最大静水引張応力 $\sigma_{t / \gamma}$ 算出した。

$$
\sigma_{t / Y}=\frac{1}{3}+\ln \left(1+\frac{a}{2 R}\right) \cdots \cdots(1)
$$

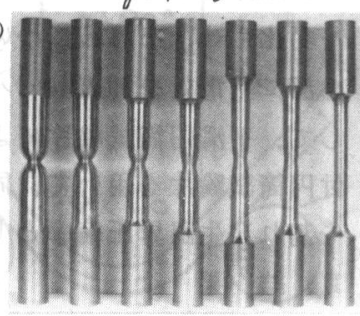

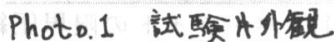

了, 结果試験结果を静水引張応力一破断えずみ一温度の三次元空间に四示したのがF i g.1 の”破壊

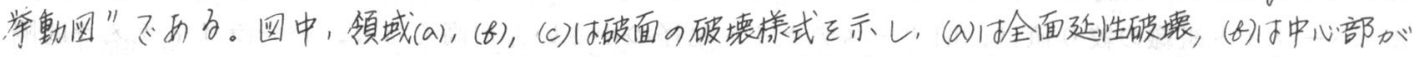

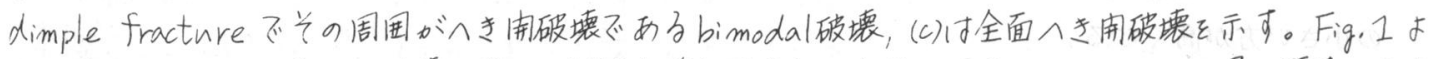

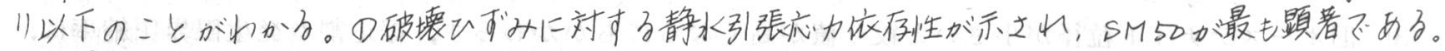

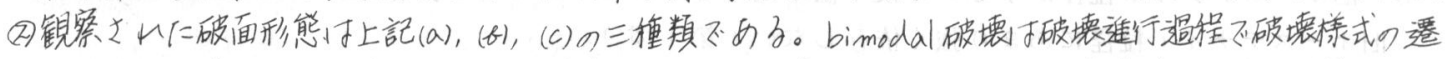

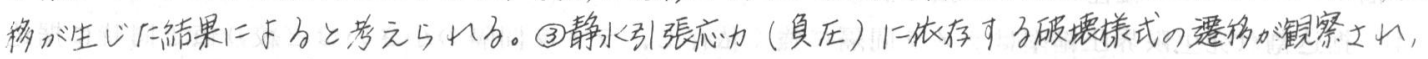
二れ、挻性一脆性透多压力（真压）の存在を示唆可子ものと考元られ子。静水引張応力状熊下不の破

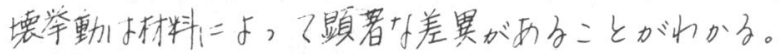
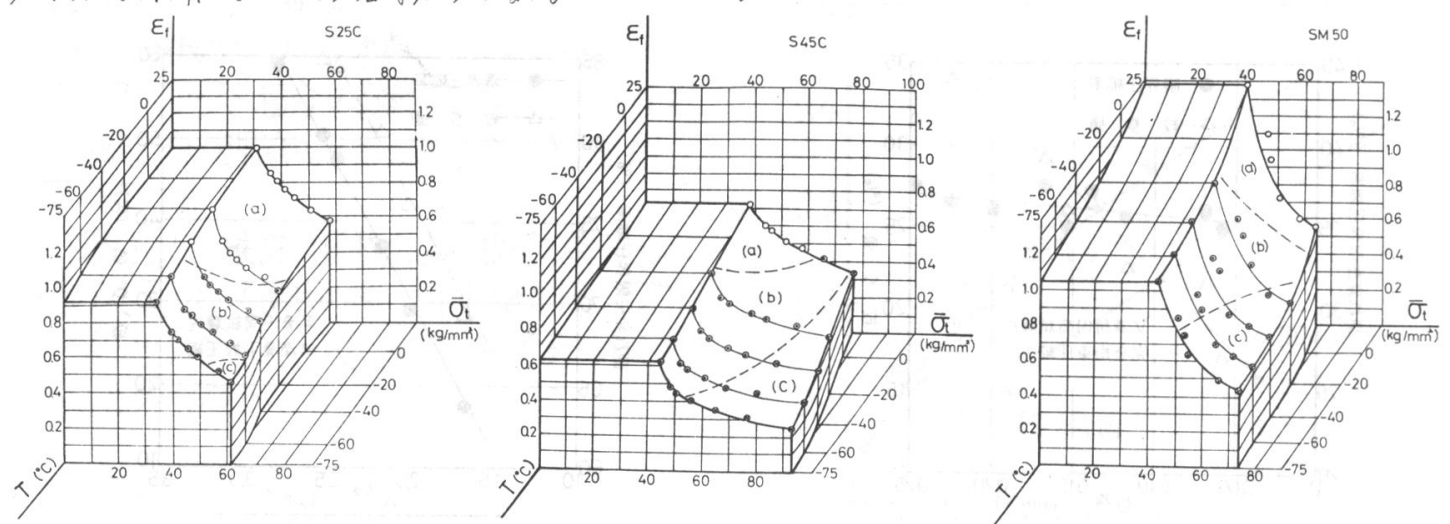

Fig 1 破塆举動四

参考文献 1)例之1 J゙, J.R. Rice \& D.M. Tracey! J. Mech. Phys. Solids 17 (1969) zol

2) D. Francois: ICF4 val.1, (1977) 805 3) I.G. Dondik: Strength Mater., (1972) 937 
角鋼片自動疵取装置

( 全自動手入システムの開発一その 2 )

(株) 神戸製鋼所機械研究所

津田五郎 ○結城 滋 浅田研究所岩崎全良木邑信夫 神戸製鉄所新村鉄三郎 小浜豊喜

\section{1. 緒言}

鋼片加工工程において、最も労働集約的な䬺見・疵取作業の自動化による省力化、コストダウンなら びに作業環境の改善は急務である。角ビレットに関して、検査以後の手入工程を含めた自動化の例は少 い。そこで、当社ではＩTVによる蛍光磁粉自動探傷装置 ( 前回竍告) とフライスカッタによる掂取装 置を結合した自動手入システムを開発した。本報ではその自動弒取装䈯について述べる。

\section{2. 㾟取装置の構成}

(1)機構部……概略構成を図 1 亿示す。践取方法は、側 フライスカッタ（超硬合金チップ）による切削方式 であり、ビレットはローラで挾まれ、送り駆動され ながら切削される。また、ビレットの曲り・変形に 追従するため、各ローラはフレームに摇動自在に取 付けられ、さらに装置全体はビレットを㣣んだ状態 で支持フレームより懸架されている。なおカッタは 切削深さ方向およびビレットの幅方向に移動可能な 構造になっており、サーボ機構により切削深さおよ び幅位置の制御が行われる。

(2)制御部…ママイクロコンピュータ (容量 $16 \mathrm{k} \mathrm{W}$ )

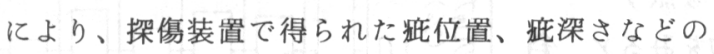
データから践取スケジュールを作成し、それに基づ いて機構部を制御する。まず、疪の合併あるいは補 間などのデータ処理を施し、趾データテーブルを作 成する。これによりカッタ（4台）に対する最適な 疵の分配と処理順序を決定する。ビレットの締付後、 との最適スケジュールに沿って、正/逆転送り制御 および践取の位置制御を自動的に行う。

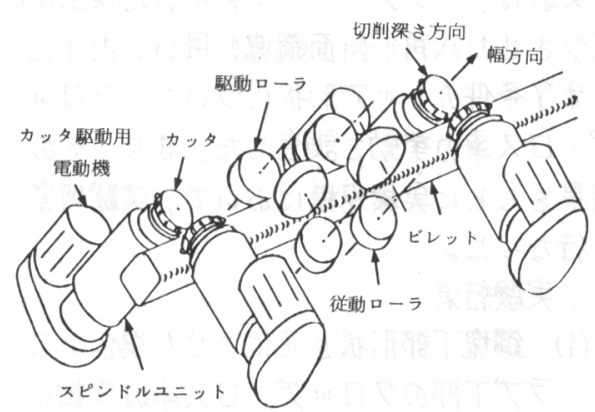

図 1 疪取装置の概略構成

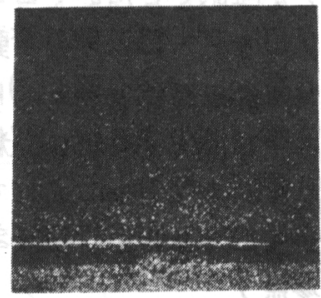

写真 1 欠 陥 (磁粉模様)

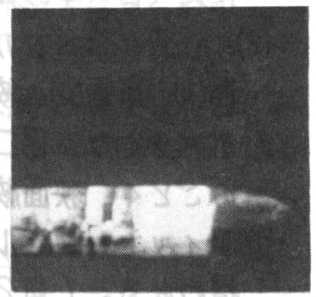

写真 2 跐取あと

3. 結果

送り速度を $3 \mathrm{~m} /$ 分 (高カーボン材)、 $9 \mathrm{~m} /$ 分 (低カーボン材)、6 $\mathrm{m} /$ 分（その他の材）とした

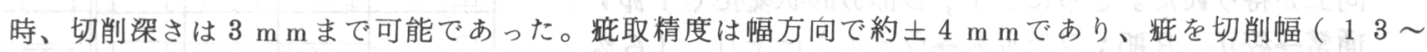
$18 \mathrm{~mm}$ ) 内にとらえるととができた。なお、切削方式のため佌取あとが滑らかで、圧延後への影響はな かった。また、最適な跟取スケジュールの作成は処理時間の短縮に効果があった。

\section{4. 結言}

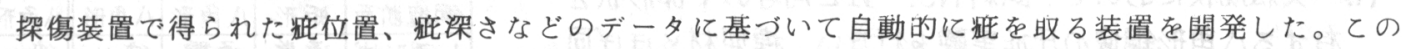
システムにより、角ビレットの表面践検査および手入が全自動で行えるようになった。

文献 1）岩崎、木邑、津田、沢田、新村、小浜：鉄と鋼、6 6（1980） No.4、S 287 
' $80-\mathrm{S} 980$

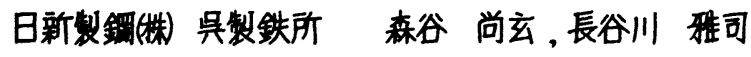
。向政登

\section{1. 緒 言}

分塊歩留の向上を四るためには，その圧延過程で生成するフィッシュテールとオーバーラップの形状 を改善することが必要である。そこで、フィッシュテールの生成抑制のため，鋼塊断面形状を八角形に するとともに，オーバーラップ防止のために錍トップ部を絞リ，分塊歩留の向上を四るう法について 検討した。

\section{2. 実験方法}

実験は，プラスティシンを用いた模型圧延（実機の1/10）によリ，四1に示す如く四濑陵部の体栍を 减少させた八角形断面銅塊を用い，表1に 示す7条件のトップ形状についマ,フロッ プ・ロス率の挙動を調査した。きた，その 結果をもとに実楼規模において，試硂研究 を行なった。

\section{了。実験結果}

（1）鋼塊丁部形状を变化させた場合のス ラブT部のクロップ・ロス率の挙動は ，試料NO.-I〜四のいず水の鋼塊に
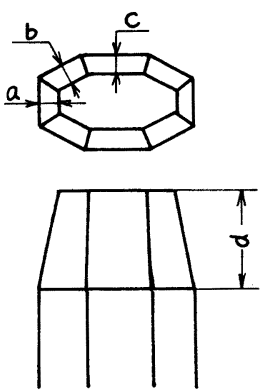

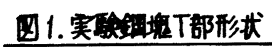
おいても，オーバーラップ牫少効果により試料No,一0 に此ベロス率の减少が確証できた。(四2参照)

（2）各絞リ条件でのクロップ・ロス承の挙動をみると，斜 面(b)，広面(C)の絞リ量およv゙絞り深さ(d)は，それらの值 が大きくなる程口ス率は減少するが，試料NO.一I，IV のごとく，狭面絞り量(a)を7.0 mm以上にすると，凸型の フィッシュテールが生成するため，ロス率の减少奻果が 損わ北る。(四2参照)

（3）模型圧延による各実験銅塊でのスラブT，B部のクロ ップ・ロス率および歩留の挙動は，四了のごとく，鎆塊 断面形状の变更（矩形＞八角形）によリ，2.0\%の步留 向上が得らKた。さらに，T，B部の形状变化（ $T$ 部； 通常 $\rightarrow$ 絞リ，B部；フラットーウェル）によリ，1.6\% の歩留向上が得ら北大。以上の結果，従来の矩形断面䤡 塊に比べ步留向上効果は，総合で3.6\%であった。

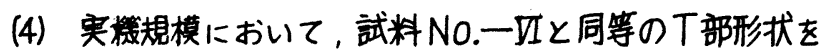
有する八角形銅塊の圧延実融を行るい，模型材とほぼ同 等の効果が確認できた。

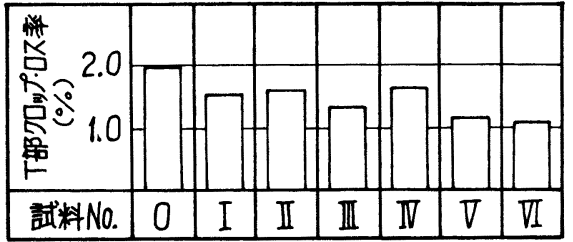

因2. 丁部形状の变化による7ロnプロ不率の举動

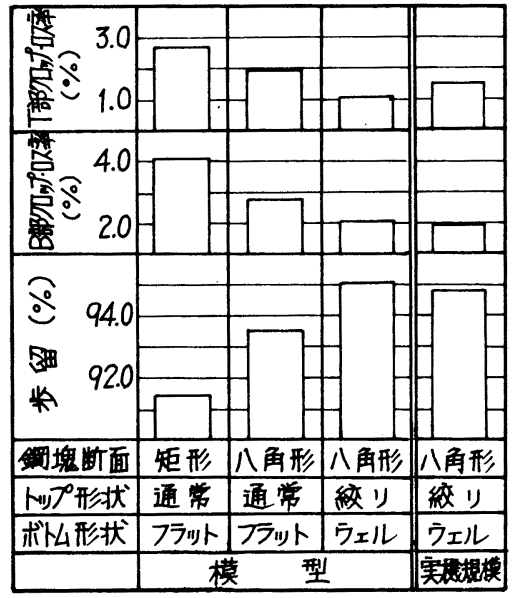

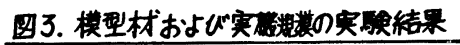




\section{川崎繁鉄干菜製鉄所 岩崎重雄峉美輔 \\ 。中萗久直 武者昌雄}

日开製作订百立工場古山文治

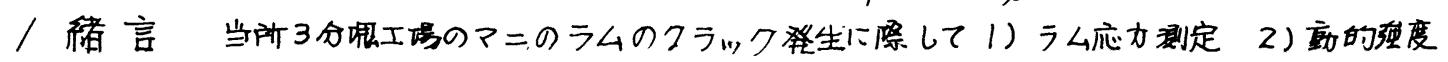
計算 3)ラム庆力分布計算をかこ〉ったのでその䅂果をここに報告する。

2 マニの構造およびクラック発生㑑䏚 ミル前面マニと後面 マニは中間軸を介して同一の動きをする。さろに詺面駆動㑭には

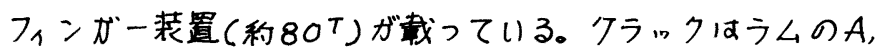

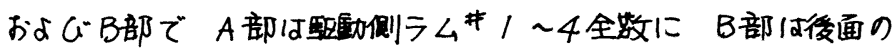

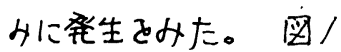

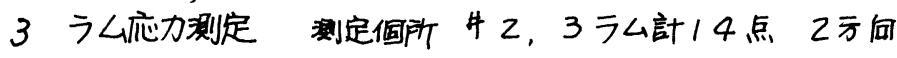
歪ゲージ，中間軸／点トルクゲージ。测定䅂果を表にに示す。

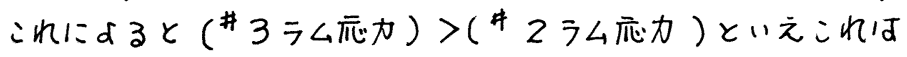

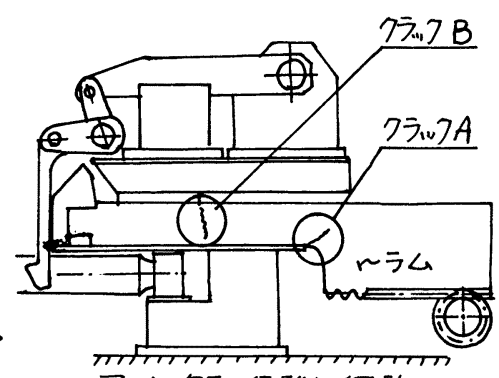

四1. クラッ登生㮯所。

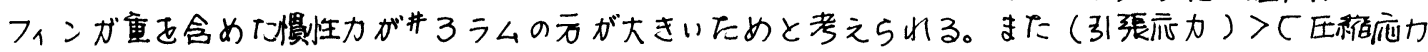

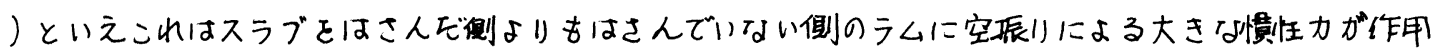
1ているためと考えられる。

4 動的強度計算 ラムに作用 する力とし各部運勒喓性による得于 椠力を考虑し計算した絽果てB部 について因てに示す。これによる とタ部は片振り摭労限界巨超之た 表/ラム娄生㐫力测定秥果

\begin{tabular}{|c|c|c|c|c|c|c|c|c|}
\hline & \multicolumn{4}{|c|}{ \# 2ラム } & \multicolumn{4}{|c|}{ \#3ラム } \\
\hline 测定点 & A.H & $A \cdot \nabla$ & $B \cdot H$ & $B \cdot D$ & $A \cdot H$ & $A \cdot V$ & $B \cdot H$ & $B \cdot D$ \\
\hline 引張方向祅力 & 110 & - & 160 & 10 & 90 & 70 & 300 & 30 \\
\hline 压䋨方向们力 & -100 & - & -40 & -10 & -100 & -60 & -50 & -30 \\
\hline
\end{tabular}

$A \cdot H$ : A点の水平方向店力 $A \cdot \nabla: A$ 点の重通方向应力 仂が承生していたことが判る。

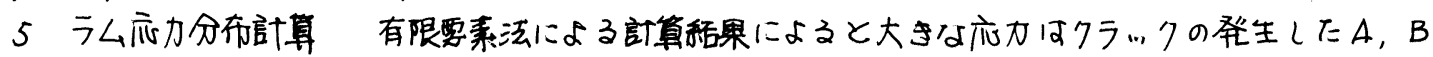

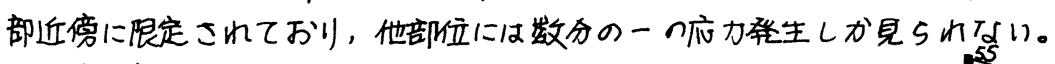

6 秙言怭上の検討からクラックは形状急变部に おける慣性による大きない九による度第で発主にたこと が判る。文策としてラムの形状の急变て極力避ける。る

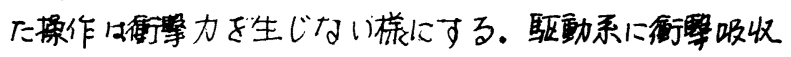
部を設けることは有动であろろ。さ5に応力の集中する

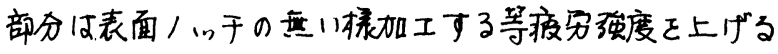
ことも考えられる。大型化，高逨化してきている慗鉄所 設借全般にゆたり，設訂，保全に当ってい設計根执往

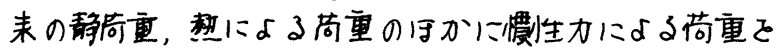
今後十分考膚する必要が有る。いたず5に部代を厚く，

重くすることは决して模械を丈夫にすることにはならず

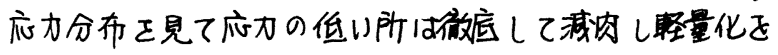
計る収要がある。

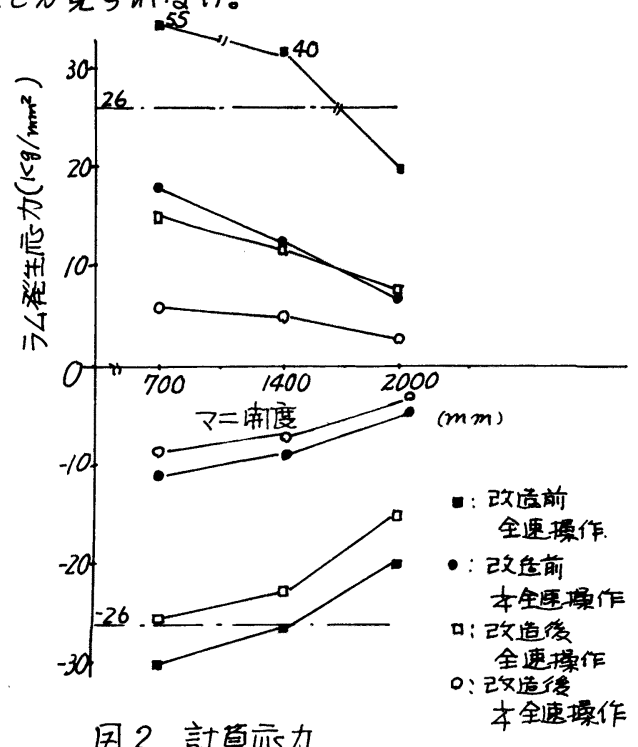

田2計萛忍力 
'80-S 982

\title{
（381） フェライト系ステンレス鋼塊の新しい分塊圧延法
}

\author{
川崎製鉄千葉製鉄所 ○松崎実, 吉村英明，小川靖夫，中里嘉夫
}

1. 緒言：分塊压延における步留向上のためには，压延中にスラブ先後端に形成されるクロップロスを 少なくすることが重要である。この改善策として，著者らは，設備などを現状のままでより一㬝の步留 向上を得る，嚙み戻し圧延法と呼ぶ新しい分塊圧延法を報告してきた(1)(2)。今回は、フェライト系ステ ンレス鋼の変形抵抗, および塑性変形挙動の解明結果から, クロップレス压延が可能となる, 強区下引 き抜き圧延法と称す，全く新しい分塊压延法(3)を開発し，実用化に成功したので闪容を報告する。

2. 強圧下引き拔き圧延法の基本原理：図1に厚み压延 1 パスに掞けるモデ

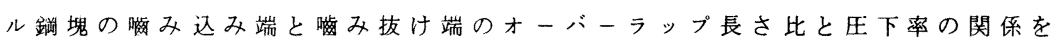
示す。これから, 圧下率の上昇に伴なって,オ一バーラップが隇少すること がわかる。しかし，1 ハ元毎の圧下量は，压延機の能力・素材の変形能等に よって異なるが, 一般的には, 喘み込み限界・トルク限界・荷重限界からの 制約により決められている。我々は, 千葉为2 分塊圧延機における通常压延 法の限界として, 表 1 に示す経騃値を把握してい る。他方，表 2 にェライト系ステンレス銅と普 通鍋の変形抵抗の操業実績値を示す。これらは, より大きな圧下量・过下率を採ろうとすると、ト 表 1 通常圧延法の战み込み限界

\begin{tabular}{|c|c|c|}
\hline & 設定 値 & 備 \\
\hline $\begin{array}{l}\text { 嘴み込み角 } \\
\text { 最大压下量 }\end{array}$ & $\begin{array}{c}\left(\mu 6^{\circ}\right. \\
122 \mathrm{~A} \\
122 \mathrm{~mm}\end{array}$ & 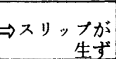 \\
\hline
\end{tabular}
ルク限界・荷重限界からくる制約はほとんど無く 嘴み込み限界によって制約されることを示唆して いる。図 2 に強圧下引き抜き生延法の模式図 を示す。啮み拔け端に向かって,メタルを素 材の厚み方向にT字状に整形し，ある時期に そのままパスを抜き去ることにより，啮み抜 け端は大压下率生延が可能となることを見出 した。この压延法によれば，啮み抜け端の鋼 塊断面中央部が外に押し出され，(1) 入力二力 表 2 変形抵抗值比較

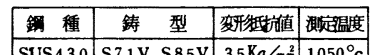
\begin{tabular}{|l|c|c|c|}
\hline 1$) \Delta F^{\circ}$ & $C_{1} 8 \mathrm{C}$ & $6.8 \mathrm{~K} / \mathrm{m}^{2}$ & $1000^{\circ} \mathrm{C}$ \\
\hline
\end{tabular}

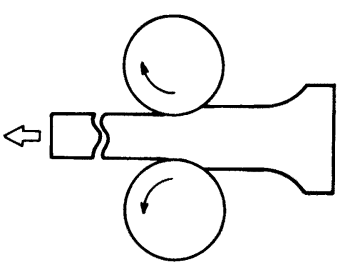

图 2 強圧下引き拔き压延法模式図 ルパイプを゙０、に抑制でき，(2)嚙み辽み端に比しでう啮み抜け端の方がよ り大きい扇形の平面形状を呈し, 後の幅压下において×タルフロ一の調整が でき，クロップレス形状にすることが可能となる。これが本仕延法の基本原 理である。図3に実鋼塊に打ける両端オーバーラップ長さ比と压下率の関俰 を示す。また, 生延負何とメカニカルパイプの减少程度, 及び最終クロップ 形状の繰り返しチェックにより得られた喽み拔け端部の適正な圧下率は表 3 に示される。

3. 結言: 強圧下引き抜き圧延法の開発後, 直ちに当社千葉製鉄所分塊工場
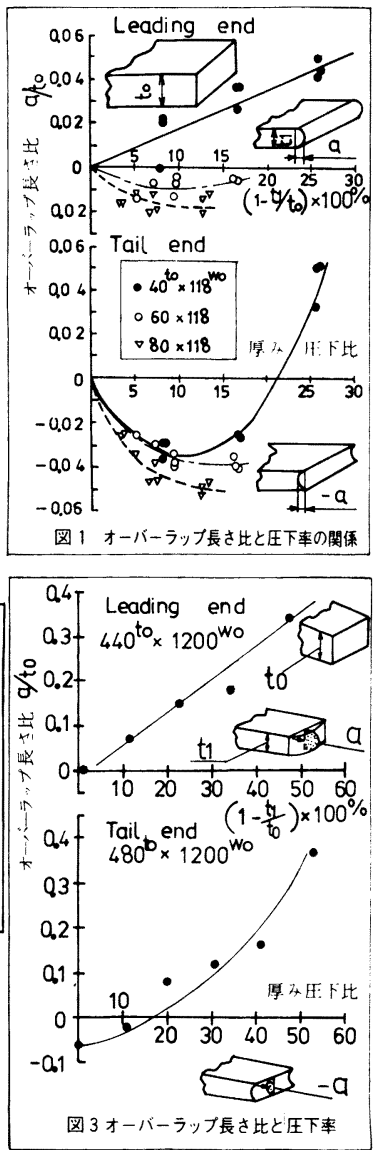

表 3 谜み拔け端部の圧下率

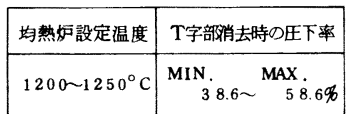
の工程操業に遒用した結果，能率を向上させながら，フェライト系ステンレス鋼の圧延歩留は, $97.5 \%$ を達成するに至っている。尚, 当生延法は他鋼種への適用も可能である。

参考文献；(1)金成ほか；鉄と鋼 $\left.6 \begin{array}{llllllll}5 & 5 & 8 & 1 & 5 & 7 & \left({ }^{7}\right. & 9\end{array}\right)$ ，

- (2) 川崎製鉄千葉製鉄所; 分塊分科会資料（分一 $50,6-1 ） ，(3)$ 特許申請中。 
' $80-\mathrm{S} 983$

\title{
（382）分塊圧延における非定常部の変形挙動
}

\author{
川崎製鉄千葉製鉄所 $\bigcirc$ 松崎実，吉村英明，小川靖夫，中里嘉夫 \\ 技術研究所金成昌平
}

1. 緒言：分塊歩留に著しい影響を及ぼす，クロップェンドのフィッシニテールあるいはオーハーラッ プの成長をおさえ，クロップ切捨て量を少なくする方法として，啮み戻し圧延法(1)(2)(3)を開発し步留の 向上を計ってきた。鋼塊から压延するスラブサイズや鋼塊形状に応じ，啮み戻し圧延法による厚み方向 あるいは幅方向の凹部の形成を有効に組み合わせることにより，クロップロスの少なくなる圧延スケジ ニールの確立が可能となるが, 我々は,より効果的な啮み戻し圧延法の追求のために, スチールを用い たモデル実験による非定常部の変形挙動の把握を試みた。得られた知見を圧延スケジニ一ルに活用した 結果，更に歩留を向上させることができたので概要を報告する。

\section{2. スチールを用いたモデル実験}

\section{表 1 実験条件}

実機における圧延時のメタルの挙動を明確に するため，1/10 縮尺のスチールモデルを用い た実験を行なった。表1に実験条件を示す。 図1に幅圧延1 ハススたける，噌み込み端と 啮み拔け端のフィッシュテール長さ比と压下

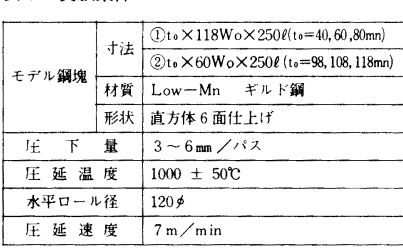
率の関係を示す。因2 2 は厚み圧延1 ハスにおける，啮み込み端と啮み抜け 端のオーバーラップ長さ比と圧下率の関係を示す。前者から，啮み込み端 に比較して嘴み抜け端の方がフィッシュテール長が大きくなることがわか る。又, 後者から, 啮み込み端は嚙み抜け端に比較して，オーバーラップ 長が小さくなる傾向は認められるが, 鋼塊厚あるいは圧下率により著しく 変化することが理解される。四 3 は， 80 to $\times 118$ wo $\times 250$ lo のモデル鋼塊に， 啮み戻し圧延を厚み方向に実施したと きの凹部先端のオーハーーラップ長さの 変化を示す。これから，才一バーラッ プの成長は最小にとどまるばかりか， 隇少することがわかる。

3. 実機操業：モデル鋼塊の压延によ る非定常部の変形挙動の把握により 改善した压延スケシューールの一例を， 因4 に示す。四中，太い破線で示す寸 法変化が，凹部先端部の挙動である。 4. 結言：嘴み戻し压延法の適正化に より，従来レベルからみると，キャッ プド銅に㧍いて約 $4 \%$ の歩留の上昇が もたらされた。
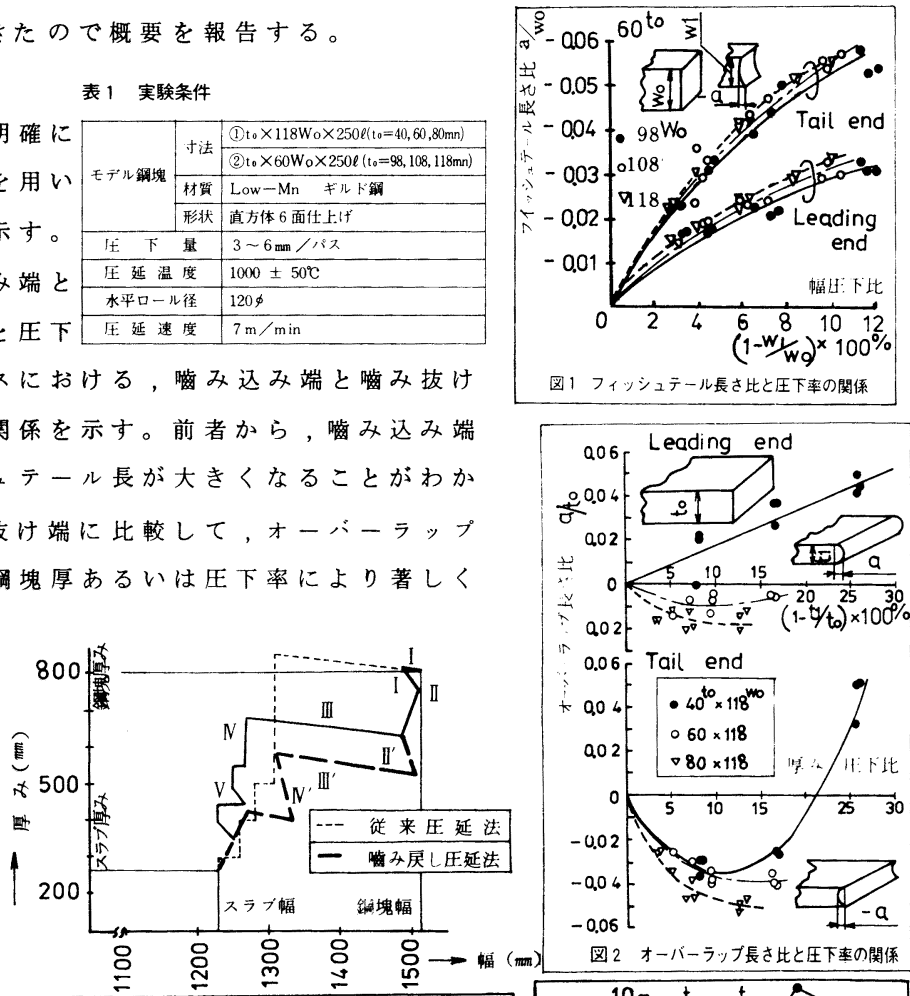

\begin{tabular}{|c|c|c|}
\hline ステーシ & 称 & 内 \\
\hline 1 & 初期王下 & 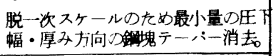 \\
\hline II & $\begin{array}{l}\text { 厚み方向 } \\
\text { み㞍し王延 }\end{array}$ & 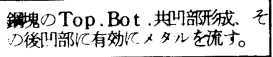 \\
\hline III & $\begin{array}{l}\text { 幅方向 } \\
\text { 嘴々戻し延 }\end{array}$ & 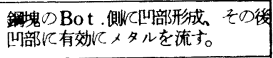 \\
\hline $\mathrm{N}$ & 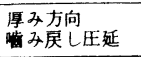 & 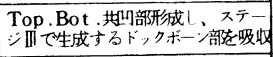 \\
\hline V & 形状整形 & 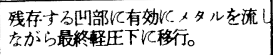 \\
\hline
\end{tabular}

参考文献；(1)川崎製鉄千葉製鉄所；分塊分科会資料（分一-45，6-1），(2)金成ほか；鉄と鋼 65，8A157 ('79)，(3)川崎製鉄千葉製鉄所；分塊分科会資料（分一50，6-1）。

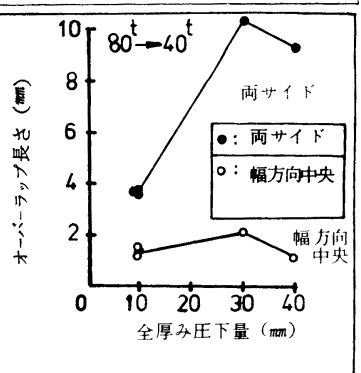

图3腈み戻し氏聇における 先端オーバーラップ長さの変化 


\section{(383)}

\section{分塊スラブの熱間渦流探傷}

（熱間探傷の研究 第 5 報）

住友金属工業(㑣) 中央技術研究所 和歌山製鉄所
白岩俊男 広島龍夫 `坂本隆秀 久保幸雄 高橋昭夫 小野富昭

(I) 緒 言

赤熱スラブの直送圧延, 温片装入を対象にプローブ型熱間渦流探傷の検討を進めている。本方式は, 前報で既に報告したように, 疪深さの定量判定が可能で, 比較的検出精度も高いという特徴を有する。 基礎検討結果に基づき今回スラブ上面全表面を探傷可能な熱間探傷システムを製作したので，本報では 装置の概要につき報告する。

(II) 装置の概要

製作した熱間スラブ用の渦流探傷装置は当社 和歌山製鉄所分塊ミルライン, ホットスカーファ 一出側に設置した。その主仕様を表 1 に示した。 本装置はノースカーフ材, スカーフ材両者に適 用可能で, 走查方法として検出ヘッド固定, ス ラブ走行方式を採用している。その特徴を下記 に示す。

(a) 検出へッド部, プローブコイルとも水冷式 で耐熱構造となっている。

(b) スラブ幅に応じて検出へッドのサイジング が可能。

（c）前端，側端部探傷機構を有する。

(d) オフラインに感度較正装置を有し, 検査前 後の装置のチェックが可能。

(e) スラブ表面疵の特徵を考慮し, 指向性の少 ないプローブコイルの採用。

(f) 各種のオペレーティングモニターを備え， 異常を早期発見できる。

(III) テスト結果

本装置は昭和 55 年 3 月に設置し, 以後 性能確認テストを実施している。探傷結 果の一例として探甥チャートと冷片目視 疵の対応例を図 1 に示した。ヒビワレ， カブレ等の有害欠陥を良好に検出してい ることがわかる。

(IV) 結 言

マルチチャンネル式スラブ熱間渦流探 傷システムを製作した。本システムは熱 間部分手入機の制御に活用することが可 能である。 参考文献(1)白岩他：铁鋼協会秋季講演大会予稿(1979)
表 1. 主な仕 様

\begin{tabular}{|c|c|}
\hline 項 & 内 \\
\hline 対 象 材 & $\begin{array}{cc}\text { 分塊スラブ } & \\
\text { スラブ巾 } & 680 \sim 1600 \mathrm{~mm} \\
\text { 厚み } & 130 \sim 270 \mathrm{~mm} \\
\text { 長さ } & 7 \sim 13 \mathrm{~m} \\
\text { 表面温度 } & 850^{\circ} \mathrm{C} \text { 以上 }\end{array}$ \\
\hline 探傷範囲 & $\begin{array}{l}\text { スラブ上面全表面 } \\
\text { 未探傷部 } \\
\text { 側端部 } 10 \mathrm{~mm}\end{array}$ \\
\hline 検査速度 & $5 \sim 70 \mathrm{~m} / \mathrm{min}$ \\
\hline 検 出 疵 & $\begin{array}{ll}\text { ワレ } & 1 \underset{m m}{\mathrm{~d}} \times 20 \underset{\mathrm{mm}}{\mathrm{l}} \text { 以上 } \\
\text { カブレ } & 5 \underset{\mathrm{m}}{\mathrm{d}} \times 0.8 \underset{\mathrm{m}}{\mathrm{d}} \text { 以上 }\end{array}$ \\
\hline 信号処理部 & $\begin{array}{l}\text { チャンネル数 } 12 \\
\text { オートバランス, A GC 機能付 } \\
\text { コンパレーター } 4 \text { 区分 }\end{array}$ \\
\hline 表 示 法 & $\begin{array}{l}\text { 疵あり (大, 中, 小), 疵なし } \\
\text { を二次元表示 }\end{array}$ \\
\hline
\end{tabular}

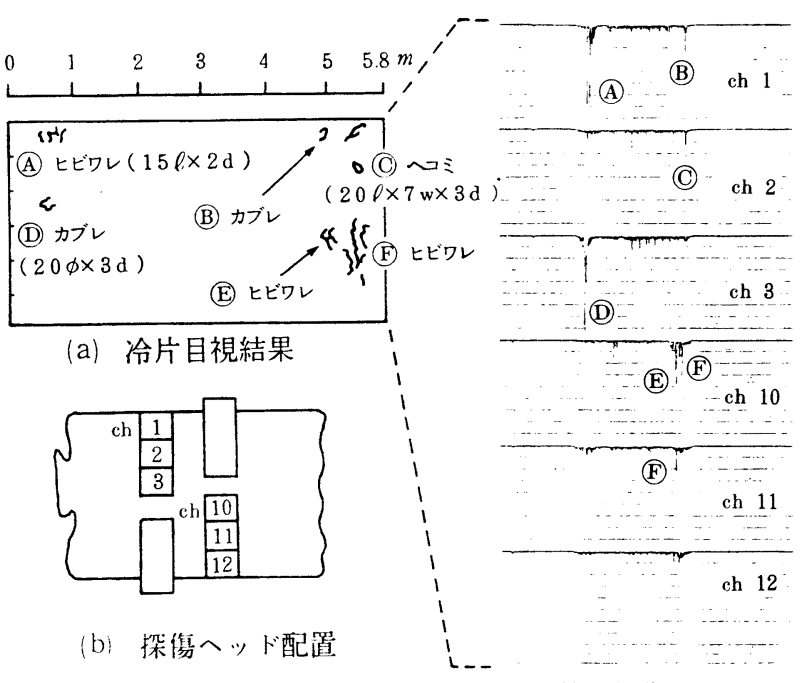

(C) 熱間探傷チャート 
620.179.142: 669.14-977: 669.14-412

' $80-\mathrm{S} 985$

\section{(384)}

連鋳スラブの熱間渦流探傷

（熱間探傷の研究 第 6 報）

住友金属工業(株) 中央技術研究所

白岩俊男 ${ }^{\circ}$ 広島龍夫 坂本隆秀 大垣一郎

\section{(I) 緒 言}

連鋳スラブの温片装入には熱間探傷が必要で, 既にタテワレの光学的探傷システムを実用化している。 しかしこのプロセスの適応拡大には, 表面及び表面直下の微少ワレの熱間探傷技術の確立が急務とされ ていた。

著者らは, 連鋳スラブの微少欠陥の検出法としてプローブ型渦流探傷法の適用に関し, 種々の問題を 検討したのでその結果につき報告する。

(II) 探傷方法

連鋳スラブを高精度に探傷するため, 探傷の防害因子となるオシレーションマークを除去し平滑な探 傷面を得る方法を採用した。そのために溶削によりスラブ表面を平滑にしながら探傷する方式につき種 々の問題を検討した。

(III) 基礎検討結果

C C M インでの探傷を前提条件として, 温間状態での溶削代 溶削後の探傷温度, プローブコイルの性能につき検討した。

(a) 良好に探傷できるための安定な溶削形状を得るためには, 溶削深さは $\min 1.5 \mathrm{~mm}$ 程度必要である。

(b) 溶削による溶削表面温度の上昇は溶削直後 ( 1 秒後) で約 $250{ }^{\circ} \mathrm{C}$ である( スラブ温度 $700{ }^{\circ} \mathrm{C}$ の場合)。

通常の C C M ラインでは溶削による温度上昇のため, 磁気変 態点以上の温度で探傷可能となる。

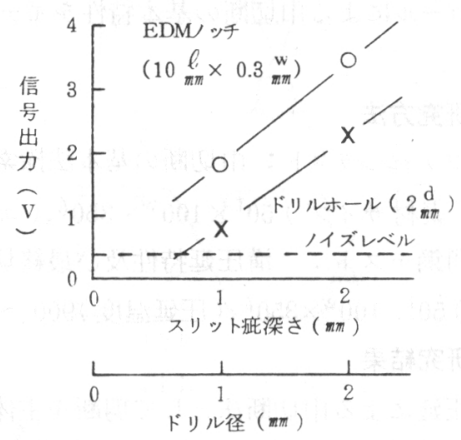

(c) プローブコイルの性能を SUS 304 鋼板を用い調查した結 果を図 1 に示した。長さ $10 \mathrm{~mm}$, 深さ $1 \mathrm{~mm}$ の人工疵を良好 に検出できる。

(IV) 装置の試作

連鋳スラブ用に開発した探傷装置は，探傷面を部分溶削する ための溶削火口とプローブコイル及び探傷へッド駆動装置で構 成され，溶削と探傷を同時に実施するととが可能である。その 概観を写真 1 亿示した。

本装置による探傷結果の一例として, 横ヒビワレの熱間探傷 結果を図 2 に示した。

(V) 結 言

連鋳スラブの微少表面ワレ検出を目的に, 溶削火口を具備し た渦流探傷装置を試作した。本装置は温片装人の判定機器とし て使用するととが可能である。

参考文献

（1）広島他：鉄鋼協会秋季講演会予稿（1979）

〈図1> プローブコイルの性能

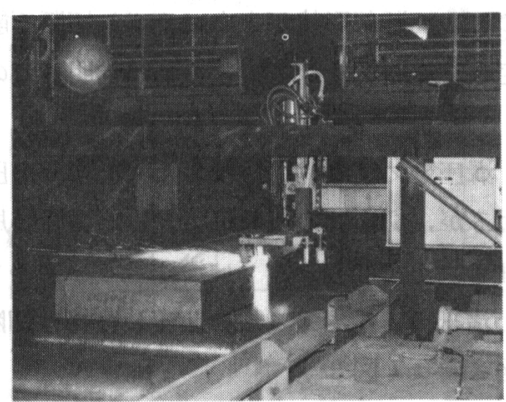

$<$ 写真 $1>$ 装置の概観 ( 鹿島製鉄所
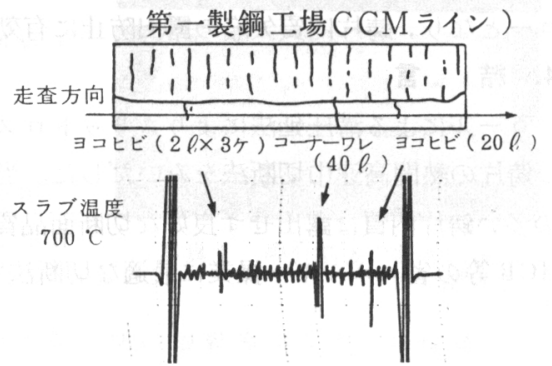

<図 $2>$ 横ヒビワレ検出例 


\section{（385）＼cjkstart鋳片のロールによる熱間巾分割の基本方式}

— 連鋳スラブの熱間巾分割法の開発 第 1 報

新日鉄, 生産研

鈴木康夫, 長田修次, ○安田一美

新日鉄 八 幡

甲谷知勝, 平川紀夫, 儀間真一

\section{1. 緒言}

連続鋳造機の生産性を高め, 製造コス卜を低減させるために狭巾スラブは通常広巾スラブを巾切断して製造さ れている。ての場合の巾切断法には従来からガス切断法が取入れられているが，ての方法で熱間切断を行うとス リットロス増大による歩留りの低下, 高速切断が出来ないととによる温度降下, 切断部の, 口処理対策等々の問 題が発生し, HDR·HCR 等の省エネルギー操業の障害になっている。当研 究はこれらの問題を解消する方法として, ロールを用いた压延により鋳片 の巾切断を行う方式を確立するとと孝目的になされたもので, 以下にその 開発概要を報告する。開発はまずプラスティシン及び小型熱間鋼を用いた モデル実験を経て, 分塊えルによる実機テス卜に至っているが, 本報は鋳 片のロールによる巾切断の基本特性をモデル実験を中心に報告するもので ある。

\section{2. 研究方法}

○プラステイシンテスト： 巾切断の基本法探索に活用(剪断法, 溝圧延法 一図 1)，(素材サイズ ) $50^{\mathrm{t}} \times 100^{\mathrm{w}} \times 350^{\ell}$, (ロール径 ) $150^{\phi}$

○熱間鋼テスト：溝圧延特性及び最終切断分離法調查に活用，（素材サ イズ ) $50^{\mathrm{t}} \times 100^{\mathrm{w}} \times 350^{\ell}$, (圧延温度) $900^{\circ} \sim 1100^{\circ} \mathrm{C}$, ( 鋼種) 普通鋼

\section{3. 研究結果}

(1) 圧延による巾切断法として剪断を主体とした方式と溝圧延を主体とし た方式の特性研究を行った。前者は噛込みの不対称性からくる材料のねじ れのため切断部形状が大巾にくずれ切断不能になる。しかし, 溝圧延法は 安定した真直切断が可能なととが判明したので後者に焦点を絞って研究し た。

（2）溝圧延による切断法は， 1 パス当りの圧下率が一定值を越えると切断 は起るが，切断前の残厚が大きいと切断鋳片は曲り，かつ大きなバリが発 生する。その曲りとバリは溝圧延ロールのフランジ先端角度を鋭角にし， かつ溝部厚みを出来るだけ薄くしたあと切断分離すると減少する。 (図2), (図 3 )

（3）切断部メタルフローは, 欠陥の多い鋳片内質を表面組織で包み込をフ ローとなり, 鋳片内質欠陥の露出防止に有効である。( 写真 1 )

\section{4. 結言}

ロールによる溝圧延法によりスリットロス零, 切断時の温度低下最小 の鋳片の熱間高速巾切断法をみいだした。当方式による切断部には, 欠陥 の多い鋳片内質は露出せず良好な切断面品質が得られるので, HDR. $\mathrm{HCR}$ 等の省エネルギー操業に最適な切断法である。

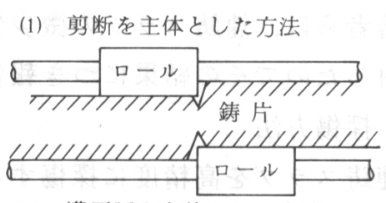

（2）溝圧延を主体とした方法

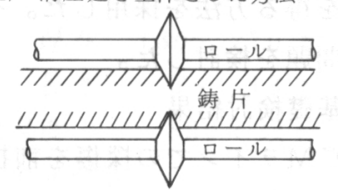

図 1 鋳片の巾切断方式

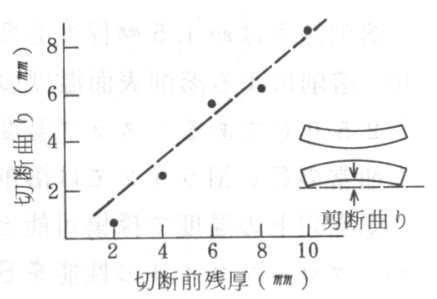

図 2. 切断前残厚と鋳片の切断曲り (熱間鋼テスト：フランジ角度 $45^{\circ}$ )

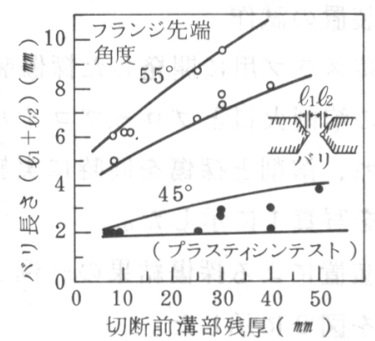

図 3 フランジ先端角度及び溝部 残厚とパリ長さの関係

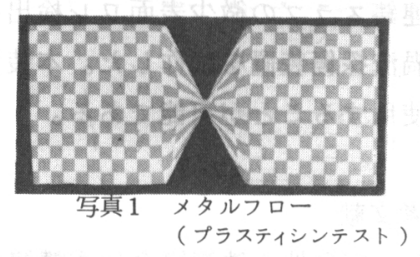


実スラブのロールによる幅分割特性

一連鋳スラブの熱間幅分割法の開発第 2 報一

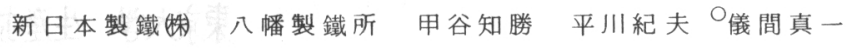

生産研鈴木康夫長田修次安田一美

\section{1. 緒 言}

第 1 報で連鋳スラブのロールによる熱間幅分割法の概念とブラスティシンの実験結果を報告した。本 報では, 実ラインにおける連鋳スラブのロールによる幅分割試験結果を報告する。あわせて, 同一フラ ンジによるリバース式幅分割法と幅分割・成形兼用技術を考案し, ロールによる幅分割特性を検討・調 查した。

\section{2. 試験条件}

スラブ温度： 820 〜 $1090{ }^{\circ} \mathrm{C}$, 圧延機：ハ1リフトミル 1 スタンドリバース式, ロール径：1 1

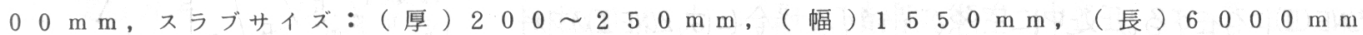

\section{3. 試験結果と考察}

幅分割用フランジによりスラブ幅の 2 分割と 3 分割は可能であり， 切離し条件は, 各々 $y \geqq 0.80 x, y \geqq 0.92 x$ で 1 パス当たり の最大減厚可能量は1 $50 \mathrm{~m} \mathrm{~m}$ である。(図1)(図2）

全パス同一フランジでの切離しも可能であるととが判明し, 単ス夕 ンドリバース方式（同一フランジで $3 \sim 5$ パス）の切離し所要時間は 60 秒未満である。

切離し面は, 屋根型形状で, 先端部は軽いバリ状になり, スラブ長 手方向に曲がりが発生する。（図1）（写真 1 ）

上記形状は, パススケジュール及び幅分割用フランジによって軽減 させるととが可能であるが，皆無にはならない。主口一ル胴長方向に 幅圧下用カリバーと厚圧下用カリバーを刻設して幅分割後に成形圧延 在行なえば，特別な装直を使用するととなく，上記形状の改善が可能 であり，かつ，所定断面サイズに応じて自由に長方形，または，正方 形にするととが可能である。

成品トレースの結果, バリによる悪影響は無く, 表面性状は良好で ある。幅分割時のメタルフロ一は, 第 1 報の予想通りに大半は外側が 包み込まれるが, 先端部は, 完全な包み込みにならない。（写真 1 ) 内質トレースの結果, 現在までに薄板, 鋼矢板及び軟線に対して適用 可能であるととが判明している。

2 分割時の圧延反力は $450 \mathrm{~T}$ 以下, 圧延卜ルクは $150 \mathrm{~T} \mathrm{M}$ 以下 で 3 分割時は, 2 分割時に比較して約 2 倍強である。

\section{4. 結}

幅分割・成形兼用技術により大断面スラブから小幅スラブや条鋼片 を製造するととは, 連鋳機の生産性向上, 鋳造 $\mathrm{T} / \mathrm{H}$ の平準化及び $\mathrm{H}$ $\mathrm{C} R$ の拡大等, そのメリットは, はかり知れないものがある。

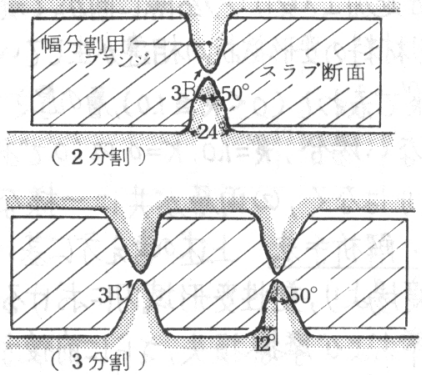

図 1. 幅分割用フランジ

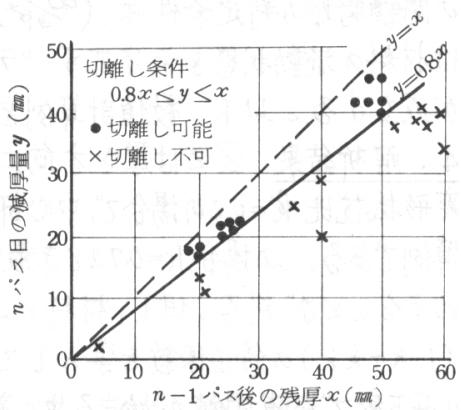

図2. 切離し条件 ( 2 分割時)

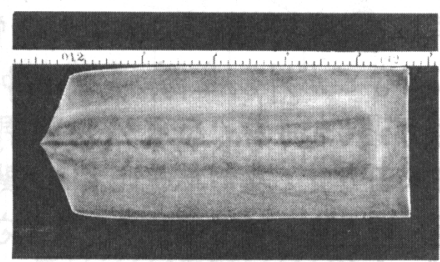

写真 1. 幅分割後の断面状況 ( 2 分割時)

実用化のための諸条件(幅分割用フランジ耐用度, 用途別適用可能品種の限界等) を, さらに確認する とともに, 分塊圧延機を有効活用した単一スタンドリバース方式の実機化を現在検討中である。 
東京大学 生産技術研究所。木内学

向四海

1.緒 言 分塊压延・厚板圧延において，銅塊内部の空览欠陥を压延加工により閉鎖・圧着させ，健 全な内部组織を得ることは，重要な課題である。筆者らは，材料内部の空䧔欠樎吕圧延中開鎖する条件 を，極限解析の手法を応用して，检討しており，既にとの結果の一部を報告してあるが，》てそれらを 小まえて新太に得られ太結果を報告する。

2. 变形王デル 本解析では，空㭞が被圧延材の厚さ方向の中央に位

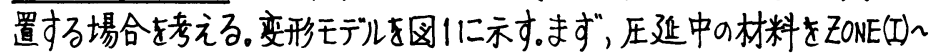

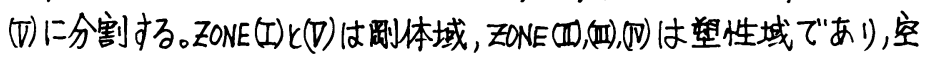
腺はZONE (III)に存在する。压延中に空隐が閉鎖する場合には,ZZNE(III)材料

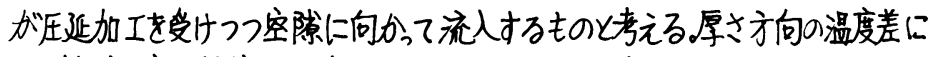
より材料の变形抵抗の相逗が生てている場合，中心部々表層部の变形抵抗比

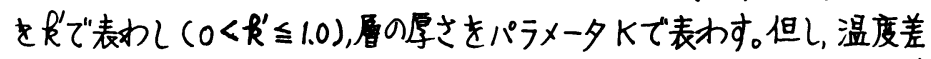
がない場合，k゙=1.0，K=0 or 1.0である。ここで(1)雨首の境界での相対す

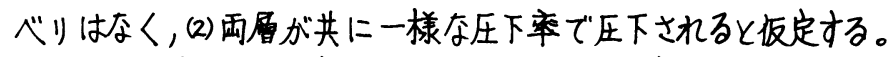
3. 解析手法上述の考元方に基いて，動的可容速度場を棈成する。の 速度場より，塑性变形域内における内部仕事率，境界における剪断仕

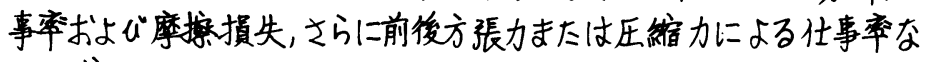
どを求め，とれらの總和としての全变形仕事率丁゙を求める。空鄍

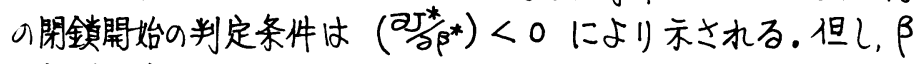

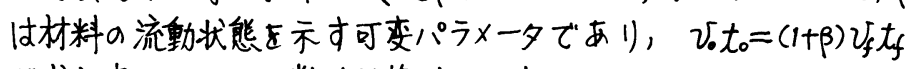
が成立する。以下，数值計算例を示す。

4.解析能果园2は厚方向に温度差があり，中心部と表首部の

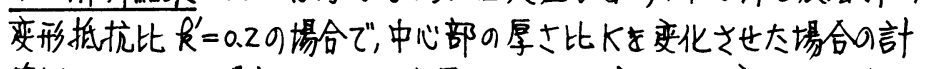

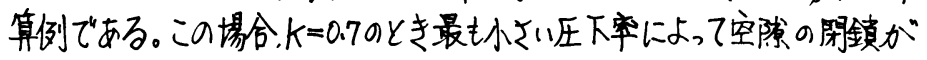
始まることが判る。但し、材料とロール間の摩擦定数 $m$ について。

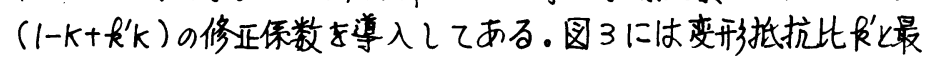

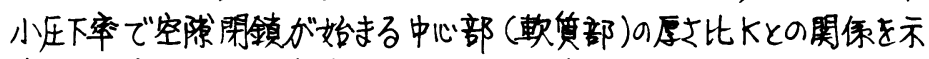

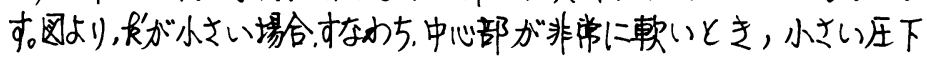

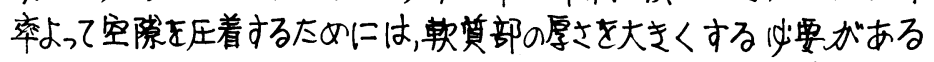

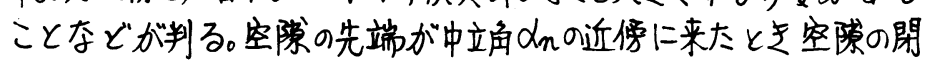
鎖が最も起川易くなるが，空除閉鎖開始の最小圧下率お゙ば最適

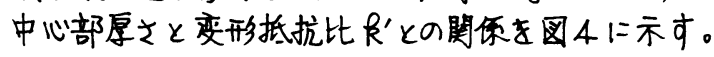

5.結言 極限解析の手法志応用して，各㮔圧延条件下でののール ギップ内における空隌の闌鎖举钦を把握することをを試み，温度差によ

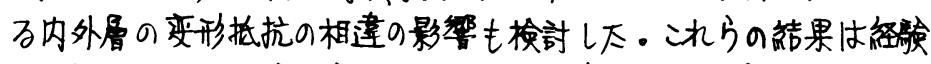
的に知ら水ている事实々定性的によく一致することが判明した。

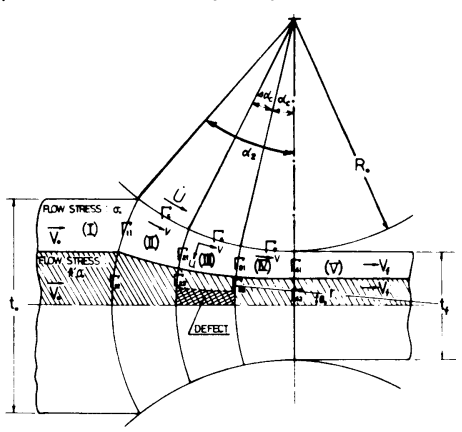

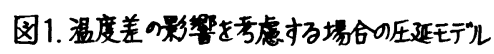

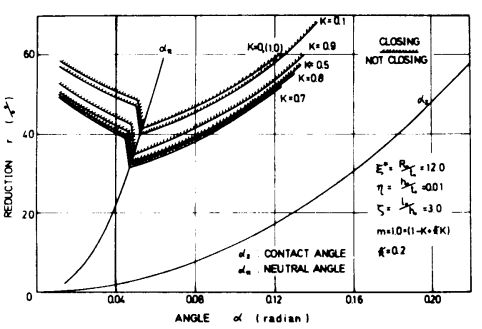

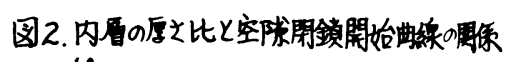

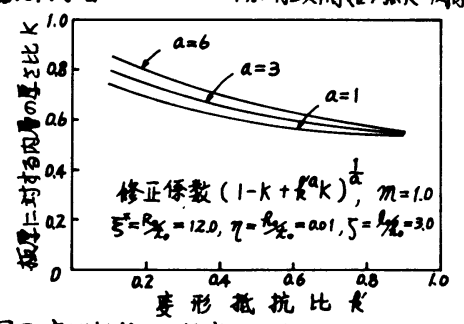

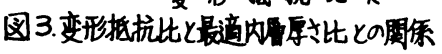

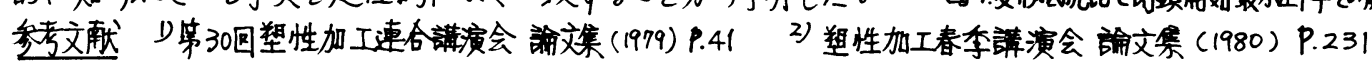

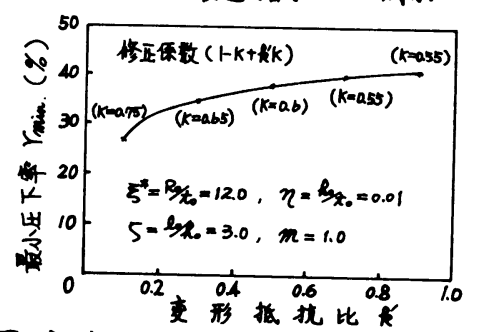

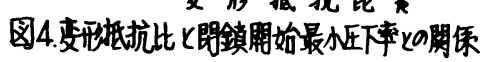




\section{(388)}

669.14-143: 621.771.23: 621.771.014.2: 620.192.47

' $80-\mathrm{S} 989$

ザク症の圧着におよぼす温度差圧延の影響

神戸製鋼所 加古川製鉄所 今村 弘朝永満男 富永雅彦。斉藤俊二 中央研究所津田 統

\section{1. 緒言}

近年、原子炉用・圧力容器用などに使用される極厚大単重鋼板に要求される敩しい内部品質を満足す るためには、大型鋼塊に存在するザク踣を圧着し、内部欠陥をなくすととは重要な課題である。 前報1)では分塊圧延時におけるザク趾の圧着に関して強王下圧延が有効であるととを報告した。本報で は、さらにスラブ表面と中心部に温度差をつけるととによる変形抵抗の違いを利用してザク疪の圧着を はかる、いわゆる温度差圧延法の効果を検討した。

\section{2. 実験方法}

供試材は高径比が 3.2 の下広 30 t鋼塊を使用した。均熱炉装 入時までの実鍋塊の熱履歴および均熱炬で用いたヒートパ夕 ーンを基に 2 次元の层熱計算モデルにより均熱炬抽出時の鋼 塊温度分布を求め、その後の圧延時の表面わよび中心温度を 推定した。なお、压延時の表面温度を実測し計算モデルを修 正するととにより温度分布を正確なものとした。压延は各パ ス同一圧下量で行ない、压延比 1.9 およ゙ 2.50 スラブを製造し た。とれらのスラブ頭部から中央部までを銅塊の軸心を含み 短辺側に平行に $200 \mathrm{~mm}$ 厚の試片を切り出し、探傷面および衰 面を研削し、UT法によりザク指数を求めた。

\section{3. 実験結果}

(1)図 1 亿通常圧延における温度差が異なる場合のザク指数分 布を示す。温度差の影響は表面温度および中心温度から美坂 ${ }^{2}$ の式を用いて変形抵抗を計算し、表面の変形抵抗を中心の変 形抵抗で除した変形抵抗比で表わした。ての結果圧延比が同 じ 1.9 の場合でも変形抵抗比が大きくなると目視可能なザク (12dB 以上) が著しく少なくなるととが認められた。 (2)圀 2 に平均ザク指数におよほすす温度差圧延の影響を示す。 圧延比が小さい 1.9 の場合でも変形抵抗比が 1.5 以上になる とザクの変形、圧着が促進されると見られ、さらに強圧下圧 延を施すととによりその効果は大きくなる。また圧延比が大 きい 2.5 の場合も同样の傾向が認められる。

\section{4. 結 論}

分塊圧延においてザク欠陥を圧着させるためには強圧下圧 延同様、温度差殴延が有効であるととがわかった。との場合 変形抵抗比が 1.5 以上で著しい効果があるととを確誌した。

\section{5. 参考文献}

1)浦本万; 鉄と鉡、65(79) 11,5828

2)美坂 $5 ;$ 住金、圧理 $(30-4)(1980)$

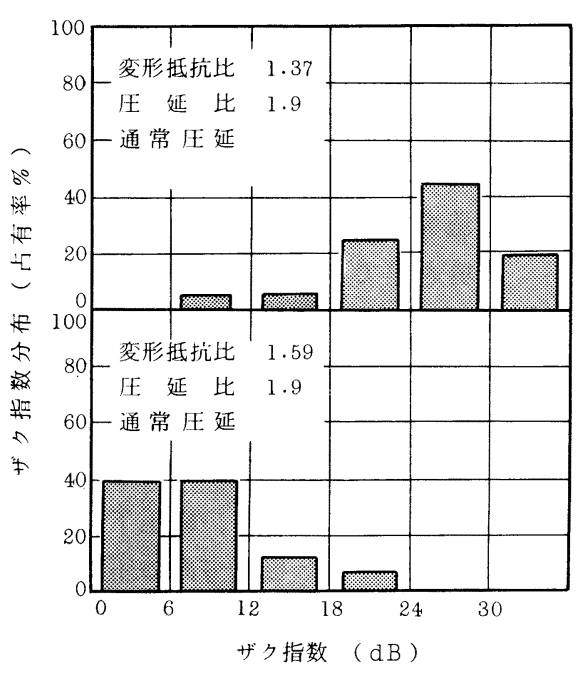

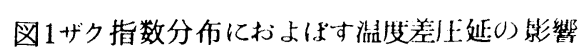

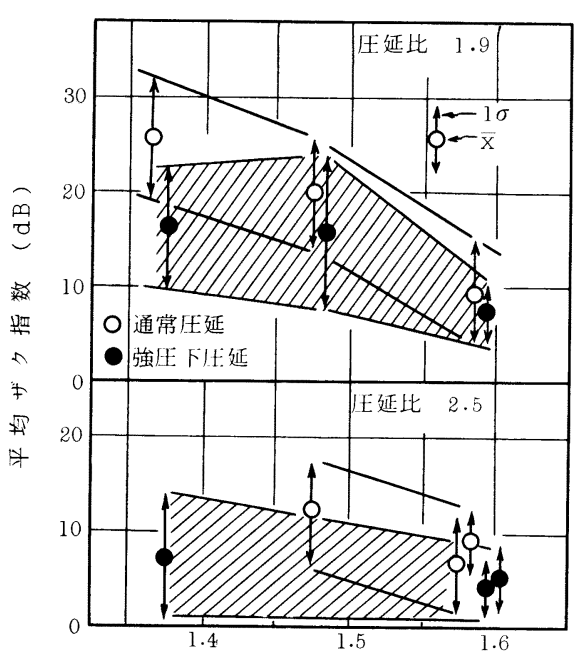

変形抵抗比〔表面/中心〉

図 2 ザク指数におよばす温度差生延の影響 
'80-S 990

$621.771 .23 .014 .3: 620.192 .34$

（389）ザク疵の圧着におよぼす圧延条件の影響

住友金属工業(株) 中央技術研究所 0 白石博章, 沖 正海

I. 緒 言

鋼塊の大型化にともない, 軸芯部の高さ方向頭部〜中央部にザク疵が発生し, 極厚材においては, こ れが未圧着となり内部欠陥として残留し問題になる。従来よりザク疵の圧着に関しては種々の研究が 進められているが, 压延のみによるザク疵の圧着方法を検討する目的で, モデル熱間圧延により圧延条 件の影響を調查し、これに基づいた実鋼塊試験，造塊方法の検討を行なった。

II. 試験内容

1. モデル熱間圧延実験

厚み, 幅方向に人工欠陥 $(4 \mathrm{~mm} \phi)$ を有する鋼片 $\left(90^{\circ}, 50 \mathrm{t} \times 90 \mathrm{~W} \times 150 \ell\right)$ を ハイリフトミル（ロー ル径 $=253 \mathrm{~mm} \phi$ ) で熱間圧延を行ない, 圧延前後の人工欠陥の圧着状況を調査した。なお压下率, 圧延速度, 加熱温度, 温度差圧延 (表面冷却, 中心温度高) 等の影響について確認した。

2. 造塊法による検討

造塊過程でザク欠陥を防止あるいは軽減することを目的として, 鋳型内に鋼材をセットしてれを溶 鋼で完全に鋳ぐるむ( 芯金鋳ぐるみ造塊法) 場合の効果を実鋼塊により確認した。

III. 試験結果

1.モデル熱間圧延実験結果（図 1 ）

1 パスあたりの圧下率を高くした強圧下圧延による久陷の圧 着効果は非常に大きく, 軽圧下圧延に比へてて圧下が材料の中心 部までよく浸透し板厚方向の不均一歪分布が改善される。次 に表面冷却を行ない中心温度の高くした温度差圧延の効果む大 きい。その他に高温圧延, 低速圧延の効果も若干認められる。

さらに板厚を薄くしても圧下の浸透度の改善効果が大きく. 板厚方向の歪分布は, 圧延後半の板厚が薄くなった段階で強圧 下圧延, 中心温度の高い温度差圧延を行なうととにより, 一層 均一化され,ザク疵の圧着効果が大きくなる。

\section{2. 芯金鋳ぐるみ造塊法の効果}

$18,26 \mathrm{~T}$ 鋼塊を用いて板厚 $=200 \mathrm{~mm}$ の厚板を芯金鋳ぐるみ造 塊法により製造した結果, 圧延比 $=4.0$ でザク欠陥を完全に防 止するととができ, 溶鋼一芯材の境界部む写真 1 亿示すように ミクロ的にも健全なものが得られた。

IV. 結 言

鋼塊軸芯部に発生するザク欠陥の圧着には厚み方向の圧縮応力 を大にする必要があり, 材料厚の薄くなった段階で強圧下圧延を 行ない,さらに中心温度の高い温度差圧延が有効である。压延 条件の改善のみでザク欠陥を完全に防止するには限界があり, 芯 金鋳ぐるみ造塊法の適用により健全な極厚プレート, ビレットの 製造が可能である。

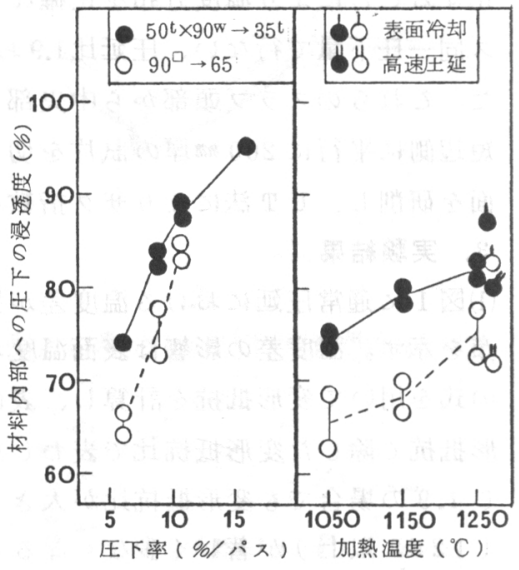

図 1. 材料内部への圧下の浸透度に およぼす圧延条件の影響

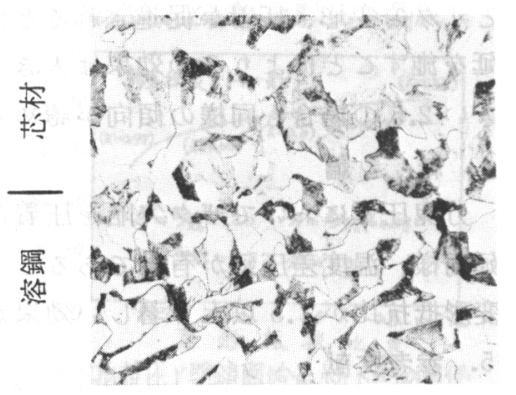

写真 1. 境界部のミクロ組織 $(\times 100)$ 
621.735 .011

' $80-\mathrm{S} 991$

（390）鍛鍊成形比が鋼材の機械的性質におよぼす影響 一鍛造比の再検討一

日本製鎆所工博 小野寺真作鈴木 公明

佐藤 育男 安藤 貴生 ○森 重夫

1. 諸言 鋼材のいわゆる鍛造比の表示法はJIS G 0701 に規定されており、これは世界で唯一 のものである。しかし本法は、鍛鍊の目的の 1 つである成形とその過程を示すのみで鍛造比が材質の 改善におよぼす影響を記述していない。筆者らは材質におよぼす鐉鍊成形比の影響を長年検討し、対 数歪表示によりあいつぐ鍛造工程の材質におよぼす累積効果を表わすととができた。 本報告では鍛鍊 効果が材料の機械的性質におよぼす影響を対数歪によって整理する方法を検討した結果について述へる。

2. 対数歪表示法 各鉎錬工程の変形量を各方向でとに対数歪で表わし、対数歪の加算によって、各 方向ごとの総変形量を求め、これと機械的性質との相関をプロットする。

3. 供試材および試験法 供試材は原子炬王力容器鋼材として広く用いられているS F V V 3 材およ びSUS 347 ステンレス鋼塊の余材を用いた。 各供試材には種々の鈠造を行なった後一定条件の熱 処理を与え機械試験を施行した。

4. 試験結果図1亿SFVV 3 鋼について繰り返し 錹鍊（鋳込みまま $\rightarrow$ 実体鍛錬 $\rightarrow$ 据え込み鈠鍊の過程を 経てもとの形状にもどす）による衝撃值の変化を示す。 鍛造比 1.5 程度までは顥著な向上がみられる。図 2 に対数歪と肉厚 $200 \sim 300 \pi$ の S F V 3 鋼の衝 搫值との関係を示す。鋳込みままの状態より一度最 少限の歪をあたえられたのちは図 2 に示すごとく各方 向の衝撃値は対数歪により一義的に評価することがで きる。引張試験の伸びと絞りの值も同様の傾向を持 つが耐力および破断強度はそれほどの有意差はない。

\section{5. 結論}

（1）鈠鍊変形量を対数歪で表わすことにより 3 方向の 機械的性質をそれぞれ一義的に評価することができる。 (2) 従来のデータにくらへて鍛錬変形量の影響は非常 に少ない。乙れは製鋼造塊法の進歩に由来するむの で、とくに偏析減少の影響が大きいと思われる。乙 のような新しい鋼材の母集団に対して鍜鍊成形比がそ の機械的性質におよほす影響について従来の規格を見 直すととを提唱したい。

参考文献

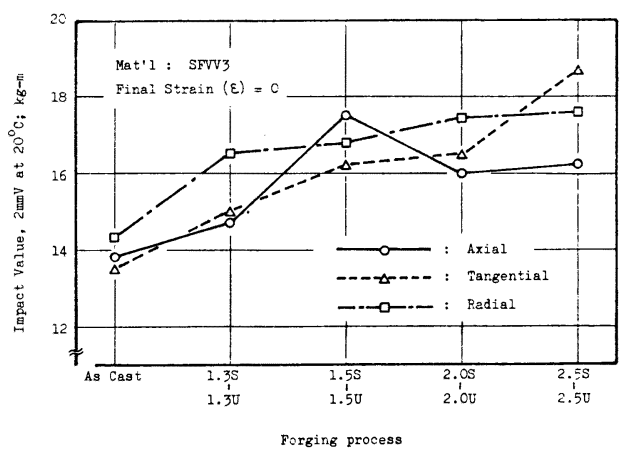

図 1 繰り返し鍛錬 v s 衝撃值

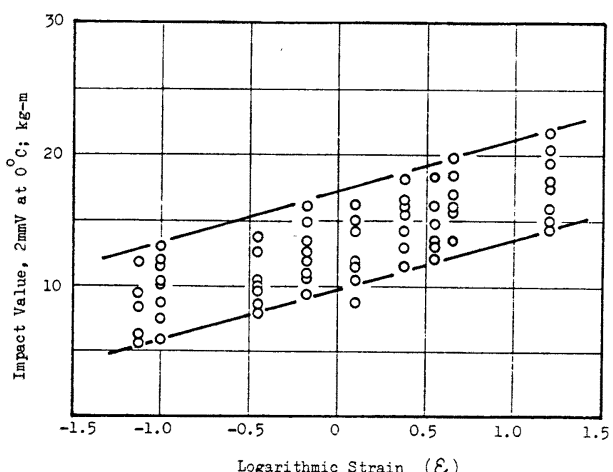

図 2 自然対数歪 vs 衝撃值

(1)近藤 八三；鉄と鋼、44 巻 6 号、P.679.

(2)Coupe $\mathrm{t} t, \mathrm{~W}$. ; S tahl u. Eisen 61, 1941, P.1013. 
'80-S 992

(391)
$621.77 .016 .2: 621.77 .011$

高速連続熱間加工シミュレーター

一高速連続熱間圧延のメタラジーに関する研究 第 1 報一

1. 緒 言 線材やホットストリップのような高速連続圧延は実験的な再現が困難なため, その熱延工程での 治金的現象は十分把握されていない。そてでてれらの圧延を冶金的にシミュレート可能な試験機を武作し，所期の 性能を得ることができたので報告する。

2. 試験機の特徵と仕様連続圧延の冶金的特徵は高 歪速度, 短い変形間時間 (図 1), および累積大圧下の 3 点である。とのすべてを充足可能な繰り返し衝撃圧縮方 式を採用した。

変形様式としては圧延に近い平面歪圧縮型を採用した。 最近これと同種の試験機が発表されているが(1) 本試験機 は横拘束治具の使用などにより, 小試片での試験を可と し、コンパクト化および高性能化を図った(図 2)。

基本性能は下表の通りであり，図1，表1亿示したよ うに多数回変形で最高平均歪速度 $300 \mathrm{~S}^{-1}$ (板厚 $3 \mathrm{~mm}$, $50 \%$ 圧下) 変形間隔約 $30 \mathrm{~m} \mathrm{~S}$ が得られている。

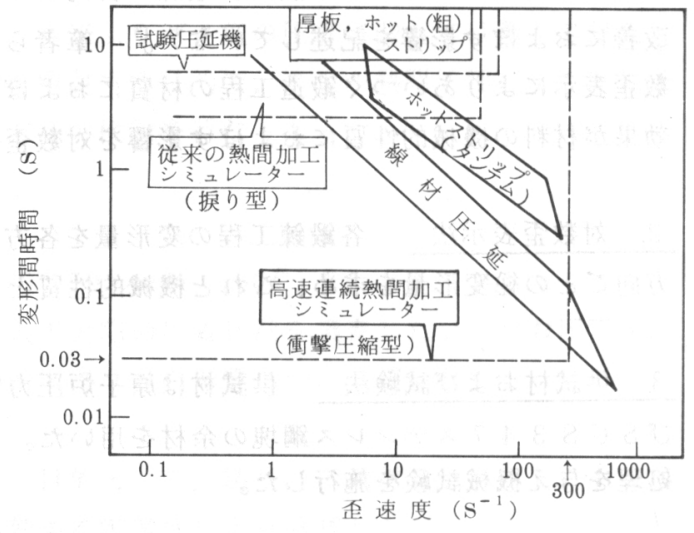

図1. 各種压延パュレート法との比較

\begin{tabular}{|l|l|}
\multicolumn{1}{c|}{ 表 1. 主 要 性 能 } \\
\hline 動 作方式 & 電気油圧サーボ方式 \\
最大加圧力 & $5 \mathrm{ton}$ \\
最大ストローク & $100 \mathrm{~mm}$ \\
最大 速 度 & $1.5 \mathrm{~m} / \mathrm{s}$ (实測 $2.2 \mathrm{~m} / \mathrm{s})$ \\
加圧回 数 & 10 回以上 \\
最小変形間隔 & $30 \mathrm{~m} \mathrm{~s}$ \\
最高加熱温度 & $1300 \mathrm{C}($ 高周波加熱, プログラム制御) \\
泠 r 却 & 水冷 $\left(\mathrm{max} 1000^{\circ} \mathrm{C} / \mathrm{s}\right)$ \\
制 御 方 式 & コンピューターによるプログラム制御 \\
\hline
\end{tabular}

3. 試験結果の 1 例 多数回変形の熱間加工組織の

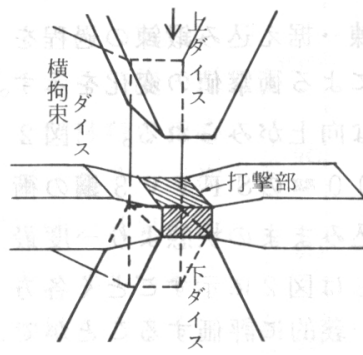

(a) 横拘束ダイス使用

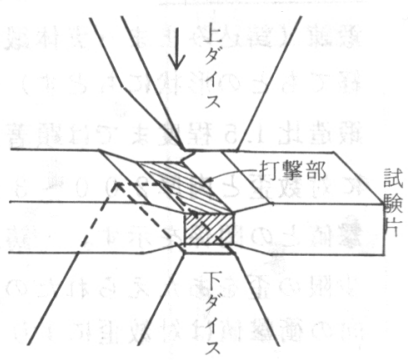

(b) 簡 易 法

図2.治具および武験片の模式図 1 例を写真 1 亿示す。乙れらの実験から得られる結論はこれまでの圧延実験の知見とよく一致しており (2) 有効なシ ミュレート法であるととがわかった。

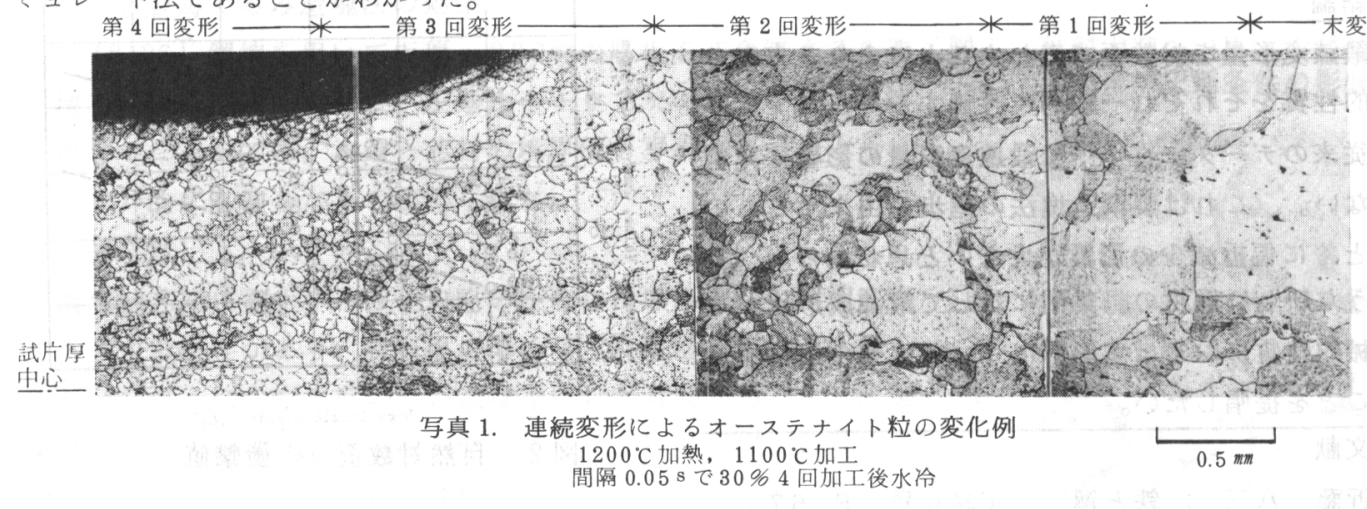
1) O.Powelski :
Z.Metallk., 68 (1977),181
2）矢田, 松津, 関根, 松村, 三浦
鉄と鋼， 65(1979)，S 880 


\section{(392) 高速連続熱間加工シミュレーターにおける変形挙動の解析}

\section{I 粕 言}

前報 ${ }^{1)}$ の高速連続熱間加工シミュレーターによる実験の解析を行うにあたり，との試験機による加工で生ずる試 料の亜状態を知る必要がある。そてで熱間加工におけるメタルフローの観察法を開発し, 熱間加工シミュレーター 実験に適用した。

\section{II 実験}

本試験機による鋼の実際のメタルフローを調査するため, $10 \sim 20{ }^{\mathbf{t}} \times 10$ $\sim 20^{\mathrm{W}} \times 220$ 乌m $_{\mathrm{m}}$ の試片を $1000 \sim 1200{ }^{\circ} \mathrm{C}$ 亿加熱後, $900 \sim 1100{ }^{\circ} \mathrm{C} て ゙ 5 \times$ $20 \mathrm{~mm}$ (接触面) ダィスで $1 \sim 4$ 回圧下した。その際, 次の 3 つの手段 を用いてメタルフローを調べた。

1. クラッド板法：低炭素鋼板と中炭素鋼板とを交互につみ重ねて 端部を $\mathrm{EB}$ 溶接後, 熱延により圧着させてクラッド板を作り,てれよ り試片を切り出す。圧下実験後, 断面をエッチングし各首の組織の差 を利用してメタルフローを調べる。

2. EB ビード法： 鋼板に電子ビーム溶接器で電子ビームによるビ 一ドを一定間隔で入れ, とれより試片を取り出す。素地とビード部と は組織の粒度, 成分が若干異なるのでェッチングで組織を現出しメタ ルフローを調べる。

3. 簡便法：ピクリン酸系エッチング液により試片の偏析部を現出 し,その変形状態からメタルフローを調べる。

\section{III 結果と考察}

1. メタルフローは, 写真 1 のようにダイス接触部直下にデッドメタ ルを生じた。ダイス中心軸上およびダイス端部の位置の試片の圧縮歪 状態は, 図 1 に示すようになり, ダィス端部位置の歪分布がほぼ均一 であるごとが明らかになった。またの部位では, 歪の長手方向成分の 板厚分布もほぼ均一であるととが判明した。

2. 横拘束治具をはずした場合の試片の加工による 幅方向, 長さ方向の変化は, 長さ方向に著しく, 幅の増 加は少なかった。試片の幅と厚みの比が 1.5 程度以上 あれば, 応力解析上, 幅方向の変化による誤差はは ぱ無視できる。

3. 簡便法はメタルフローの概観を知るのに適し (写真 2 ), 他の 2 法は歪量を定量的に知るのに適す る。以上の方法は, 熱間圧延におけるメタルフロー の観察にも応用可能である。

1) 矢田, 松津, 関根, 二村：「高速連続熱間加工シミュ レーターについて」鉄と鋼, 第 100 回秋季鉄鋼協会講演会

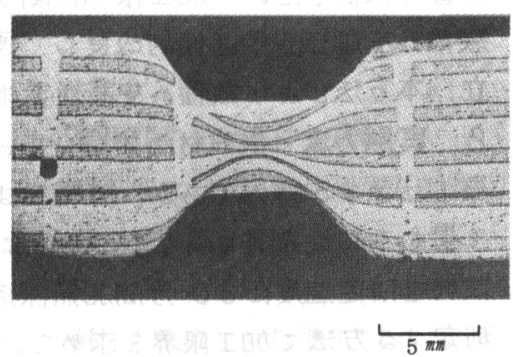

写真 1 ビード入りクラッド鋼板の変形例 ( L 断面)

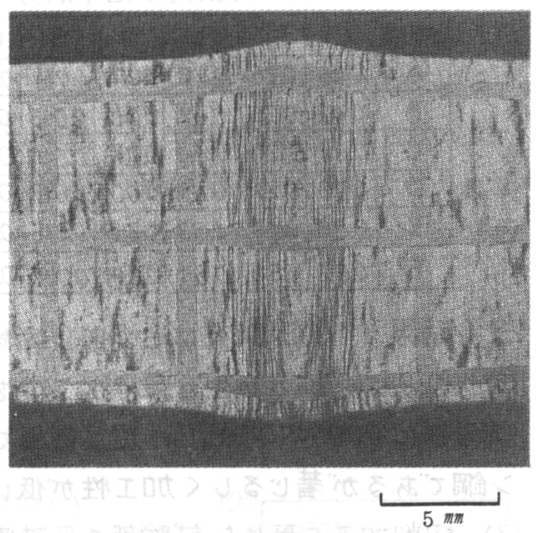

写真 2 ビード入り鋼板の変形例 ( $\mathrm{Z}$ 断面) (格子模梯がピード)

$62 \%$ 圧縮試片

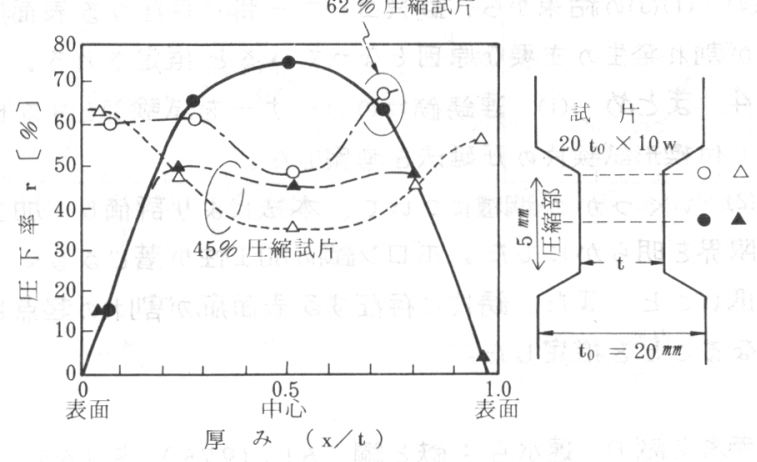

図1歪の厚み方向分布例 


\section{住反電気工業(株) 特殊線事業部山田勝彦, 福田俊夫 研究開発本部。橋本義弘}

1. 緒言 連鋳鋳片のオシしーション・マーク，シワ、へア・ワラックなどの横方向の微小表面欠宿 が初回の熱間加エにおいて拡大し，有害な疵となることは、しばしば経験されている。著者らは，連鉡 鋳片のブレイク・ダウン・ミルの設計に当って、この横方向の割れ㾟の生成防止、あるいは拡大を抑制 するための適正な压延条件の設定を目的とし、割れ疵の発生におよぼす圧延温度，加工度、圧延方法の 影響を検討した。加工限界に関する評価手段として最近、難加工材料について適用されている楔形試 験片の圧延法(1)(2)を検討改良し、連鋂鋳片コーナ一部を試験部とするヒレ付き楔形試験片の圧延法を確 立，本方法により数種の中高炭素鋼の加工限界を明らかにした。

2. 実験方法 供試材はオイルキャスト法で製造された115中連鋳錆片を用いた。対象とした鋼種は 表けに示す6種類である。試験片は图け(a)に示すように錆片コーナー部から切り出し、割れ発生に対し て最も不利な条件である引張のみによって試験部が加エされるようヒレ付楔形に切削加エした。この試 験片を所定温度に 30 分間加熱保持後、図に(b)に示すように平ロールで圧延し、割れ発生位置の伸でを 測定する方法で加エ限界を求めた。本試験方法に先立ちヒしなし試験片についても同様に実験した。

表 1。供試材の化学成分 $(w+\%)$

(a)

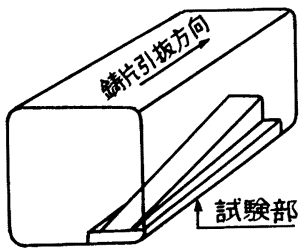

回1，試驗片採取位置七試験方法 (b)

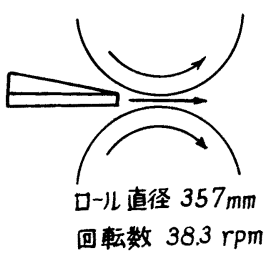

\begin{tabular}{|c|c|c|c|c|c|c|c|c|}
\hline 鋼種 & $C$ & $S i$ & $M n$ & $P$ & $S$ & $C u$ & $B$ & $t-1$ 数 \\
\hline$A$ & 0.36 & 0.28 & 0.80 & 0.009 & 0.014 & 0.02 & 0.0055 & 8 \\
\hline$B$ & 0.42 & 0.27 & 0.49 & 0.013 & 0.015 & 0.02 & - & 6 \\
\hline$C$ & 0.62 & 0.27 & 0.48 & 0.013 & 0.014 & 0.02 & - & 6 \\
\hline$D$ & 0.70 & 0.27 & 0.49 & 0.009 & 0.013 & 0.02 & - & 6 \\
\hline$E$ & 0.80 & 0.27 & 0.53 & 0.008 & 0.015 & 0.02 & - & 5 \\
\hline$F$ & 0.59 & 1.55 & 0.81 & 0.011 & 0.007 & 0.01 & - & 5 \\
\hline
\end{tabular}

(1)割れは上し部に断続的に発生する。

3. 結果

(2)四 2 は、割れ発生の最低加工度を示し、連錆鋳片コーナーに相当する試験部では、各鋼種とも，ほ ぼ同様に900〜1000ㄷの温度範用で割れ易く、これより高温、低温の方が割れ難い。鋼種Aは含ボロ ン鋼であるが著心゙るしく加工性が低い。また鋼種下は低温領域での加工性が劣る。

（3）切削加工を受けた試験部の反対側ヒし部には，どの鋼種においても，害験条件範囲で、割れの発生 は、まったく認められなかった。

(4)、(1)(3)の結果から、鋂片コーナー部に存在する表面疵 が割れ発生の主要な原因となっていると推定される。

4. まとめ (1) 連銓鋳片のコーナーを試験部とする上 し付楔形試験片の圧延法を考案した。

(2) いくつかの鋼種について、本法により評価し、加工 限界を明らかにした。ボロン鋼の加工性が著じるしく、 低いこと，また、鋳片に存在する表面疵が割れの起点と なることを推定した。

参考文献 1) 速水的：鉄と鋼，61(1975)，S163

2) 長谷川放：鉄と鋼，63(1977)、S175

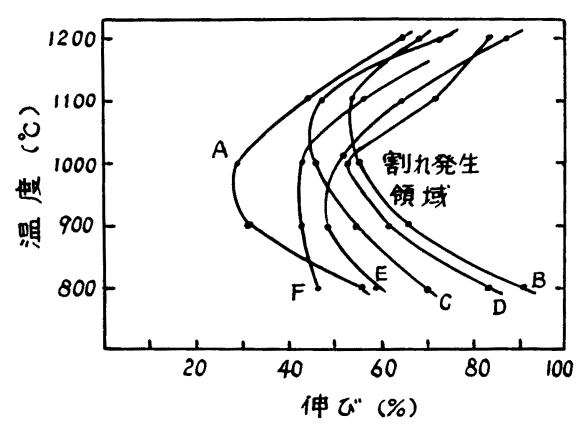

因2、連鋳鏻片コーナー部の笽間加工性 


\section{(394) 中炭素鋼の鋼片ワレ}

'80-S 995

(神戸製鋼所 中央研究所 (工博)井上 毅 横山忠正 ○外山雅雄 加古川製鉄所柴田隆雄 松井秀雄

\section{1 緒 言}

低炭素キルド鋼における鋼片表面の龟甲ワレは, 均熱炉装入時に発生する初析フェライトネットワークと $\mathrm{A} \ell \mathrm{N}$ の析出に起因する鋼塊表面皮下でのワレが原因と考えられている。 また， $\mathrm{A} \ell, \mathrm{N}$ の高い中炭素鋼片においても， 同様のワレが発生するととがある。そこで, 中炭素鋼におけるワレについて調べた結果, 初析フェライトの析出 しないオーステナイト低温域においてもワレが発生するてとがわかり，乙の場合の熱間延性低下の原因について 若干の検討を行なった。

\section{2 実験方法}

中炭素鋼鋼片の亀甲ワレ発生頻度と成分，操業条件の関係から，龟甲ワレが発生しやすい条件を調べた。

この場合の均熱炉装入時鋼塊表面温度を測定すると共に均熱炉装入後の鋼塊を冷塊にしワレ発生場所を調査し た。また, 表 1 の成分の供試材を用い歪速度約 $2 \times 10^{-3}$ で熱履歴を変え高温引張試験を行なった。

\section{3 実験結果}

(1) $\mathrm{A} \ell$ を $0.05 \%$ 程度含む中炭素鋼においては， $\mathrm{N}$ 含有量が $80 \mathrm{ppm}$ 以下では鋼片の亀甲ワレは発生しないが, $80 \mathrm{ppm}$ 以上になると $\mathrm{N}$ 含有量の増加に伴ないワレ発生頻度も増大する。（図 1 ）

（2）ワレは鋼塊トップからミドルまでの表面中央部に発生する。ワレが発生した鋼塊表面部での均熱炉装入時 温度は $660 \sim 875^{\circ} \mathrm{C}$ であり，鎘塊表面皮下でオーステナイト温度域であるととろでもワレが発生している。

(3) 図2 の高温引張の結果から, 鋼塊冷却時のオーステナイト域 $\left(725^{\circ} \mathrm{C}\right.$ 以上)においてはワレ発生するよう な脆化温度域はないと考えられるが, 図 3 のようにオーステナイト低温域に一旦保持後 $900{ }^{\circ} \mathrm{C}$ にげると脆 化現象が起る。乙れはオーステナイト低温域に一旦保持するととによりオーステナイト粒界への $\mathrm{A} \ell \mathrm{N}$ 等の析 出が促進するためと考えられる。

（文献 1）山中ら；鉄と鋼，65(1979),P 1410

表 1 供試材組成（\%)

\begin{tabular}{|c|c|c|c|c|}
\hline $\mathrm{C}$ & $\mathrm{S} \mathrm{i}$ & $\mathrm{Mn}$ & $\mathrm{A} \ell$ & $\mathrm{N}$ \\
\hline 0.57 & 0.20 & 0.86 & 0.056 & 0.0113 \\
\hline
\end{tabular}

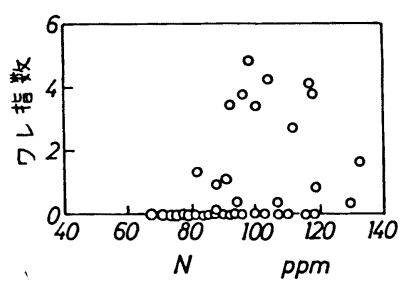

図 1

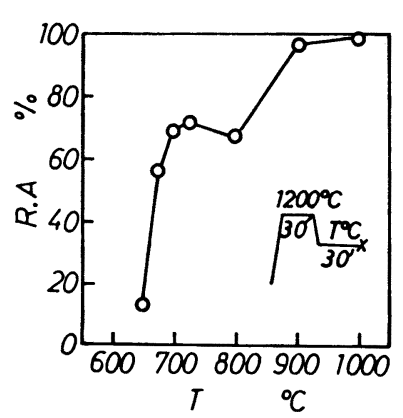

因 2 各温度での高温延性

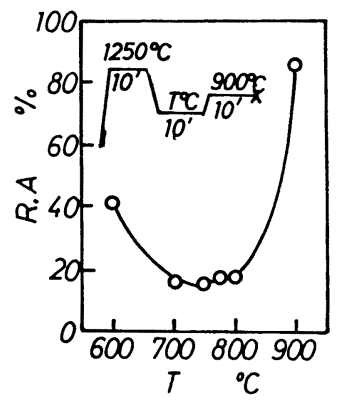

図 3 一旦 $T^{\circ} C$ K保持後の $900{ }^{\circ} \mathrm{C}$ の延珄 


\section{（395）低合金鋼の熱間変形能とAI 含有量の関係}

（株） 日本製鋼所 材料研究所

石黒 徹 ○池ヶ谷明彦 工博 大西敬三

1. 緒 言

結晶粒の微細化を目的としてAIを含有する低合金鋼では、熱間鍛造あるいは熱間成形時にAIに起因す る熱間での粒界破壊現象がしばしば経験される。この対策を講ずるためには粒界の脆弱化が生じる温度 域、諸々の外的条件の影響亚びにその機構を明確に把握しておくことが重要である。本研究ではMn- $\mathrm{Ni}$ -Mo 鋼の適正な熱間加工条件の探索を目的として、特にAI 含有量に注目し、熱履歷と材料の熱間での脆 化現象との関連を把握するとともに、AIN の固溶一析出挙動の調査結果をもとに考察を行なった。

2. 実 験 方 法

$0.2 \% \mathrm{C}-1.4 \% \mathrm{Mn}-0.7 \% \mathrm{Ni}-0.5 \% \mathrm{Mo}$ 鋼を基本成分とし、Al含有量が異なる供試材（sol Al 0.0 $09 \sim 0.028 \%)$ を用いて $800^{\circ} \mathrm{C} \sim 1450^{\circ} \mathrm{C}$ の高温度域で引張試騃を行なった。試験は主として

（1）高温加熱後降温過程（2）高温加熱後室温まで炬泠し、再加熱時の逆変態一粒成長過程 の2 つの条件での変形能に注目して行なった。また引張試験と同様の熱履歴を与えた場合の A IN の析出挙動 をエステルーハロゲン法により調査し考察を行なった。

3. 実 験 結 果と考察

図 1 は試験結果を概略とりまとめたものであり、AI 含有低合金 鋼の熱間脆性の特徵が以下の如く指摘できる。

（1）高温加熱後の炉冷過程で熱間変形能の低下は $1050{ }^{\circ} \mathrm{C}$ 以" 下の温度域で生じ、Al 含有量が低い場合にも粒界破壊を生じた。

（2）高温加熱後室温まで炉冷し、再加熱中の再 $r$ 化時に熱間延 性に及ぼすAI含有量の影響が顕著に認められた。すなわちAl含有 量の高い試料では逆変態によっても延性は回復しない。

以上の脆化現象を理解するため、上記と同一条件でのAIN の析 出挙動を調查した結果、高温加熱後の炉冷中にAIN の析出は起こ り難く、むしろ再加熱過程で析出が生ずるととを見い出した。ま たAIN が再固溶する温度域で延性は回復しており、上記脆化現象 は昇温過程での AIN の析出挙動と密接に関連するものと云えよう。

一方図 2 は上記各条件における熱間変形抵抗を示した結果の例 である。応力ー歪線図から把握される熱間変形抵抗は試験前の熱 履歴により明らかに相異しており、特に高温加熱後急速水冷した 場合は熱間変形抵抗が高く、脆化の程度も大きい。またAl含有量 の高い試料で熱間変形抵抗が高くなるととが確認された。従って 再加熱過程でのAIN の微細析出が粒内の変形抵抗を増大させ、粒 界への歪集中度を高める結果、逆変態過程での熱間脆化現象が現 われるものと推察される。

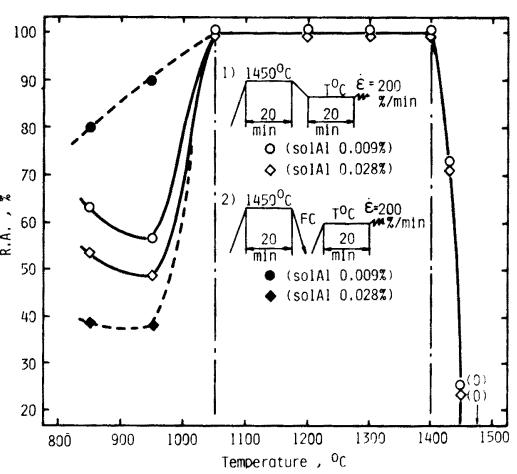

図 1 変形能と温度 - 熱履歴の関係

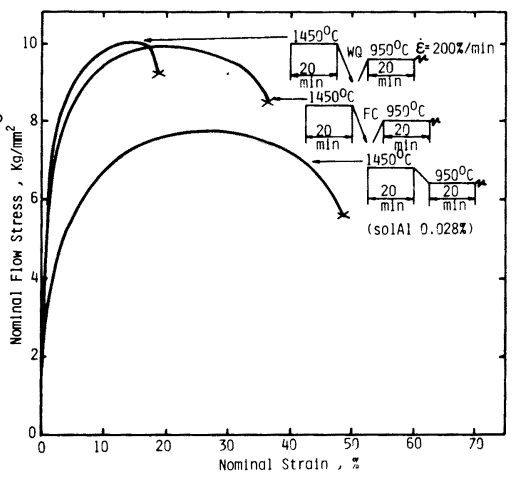

図 2 熱履歴による变形抵抗の相異

\section{4. まと め}

Al含有低合金鋼の熱間船性の特徵を実験的に把握した。 


\section{（396）傾斜ロール圧延機のガイドシュー負荷}

' $80-\mathrm{S} 997$

新日鉄 八幡 ○吉原征四郎 合田照夫

\section{1. 緒言}

中径シームレス鋼管は傾斜ロール圧延機（ピアサ, エロンゲータ）で大半の加工が行なわれている。ての圧延 機では材料に著るしい剪断変形を与えながら肉厚を 2 分の 1 以下にするのが普通である。管の内部はプラグにより 穿孔又は圧延され，外部は傾斜ロールによりスパイラル運動を受けながら圧延され，ガイドシューに押圧されその 運動方向の伸びをそれと直角方向に変換される。ガイドシューは能率, 歩留, 工具原単位に大きな影響を及ばして いる。本報ではガイドシューの負荷軽减法について紹介する。

\section{2. 実験条件}

試験圧延機：2ロール式横型熱間モデルピアサ；モータ容量 AC $200 \mathrm{KW}$, ロール回転数 $64 \mathrm{rpm}$, ロール寸法 $370 \phi \times 270 m m$, ロール形状 バレロール (入側 $3^{\circ} 30^{\prime}$,出側 $1^{\circ} 00^{\prime}, 2^{\circ} 00^{\prime}$ ) , ガイドシュー形状 円弧溝パラレル タイプ,プラグ形状 定圧下率タイプ（ $\left.\mathrm{R}_{\mathrm{t}}=15 ， 20 \%\right)$ 。

被圧延材料：低炭素鋼鋼管; 素管外径 $80 \sim 90 \mathrm{~mm}$, 素管肉厚 $8 \sim 20 \mathrm{~mm}$, 仕上外径 $80 \sim 90 \mathrm{~mm}$,仕上肉厚 $4 \sim 10 \mathrm{~mm}$, 圧延温度 $1200^{\circ} \mathrm{C}$ 。

ミルセットアップ:ロール傾斜角 $(r) \quad 4^{\circ}, 5^{\circ}, 6^{\circ}, 7^{\circ}, 8^{\circ}$, ロール間隔 $(\mathrm{RG}) \quad 80 \sim 90 \%$, シュー間隔 $(\mathrm{SG})$ $80 \sim 94 m m ， フ ゚ ラ ク ゙$ 位置 設計基準位置。

\section{3. 実験結果}

（1）シュー荷重 ( S . S / A ) は短型プラグ （Rt \大）ほど低くなる。

（2）シュー荷重 (S) はロール傾斜角 $(r)$ が小さいはど低くなる。

（3）シュー荷重（S）が高くなり過ぎると 前進速度（前進角 $\alpha$ ) が低下する。

（4）ロール傾斜角 $(r)$ が小さくなると外 径 (D) が縮少される。

（5）シュー荷重 (S)はロール間隔 $(R G)$ を小さくすると低下する(肉厚は薄くなる)。

（6）シュー荷重 $(S)$ はシュ一間隔 $(S G)$ を大きくすると低下する（外径は大きくな る)。

（7）No.2 エロンゲータでは圧延荷重（R） の高いプラグはシュー荷重 (S ) が高い。

（8）No.2エロンゲータではシュー間隔を 大きくすると伸び（e）が低下する。

\section{4. 結 言}

実機では測定困難なガイドシュー負荷の 挙動を示した。ピアサーおよびエロンゲータ 作業への応用を期待したい。

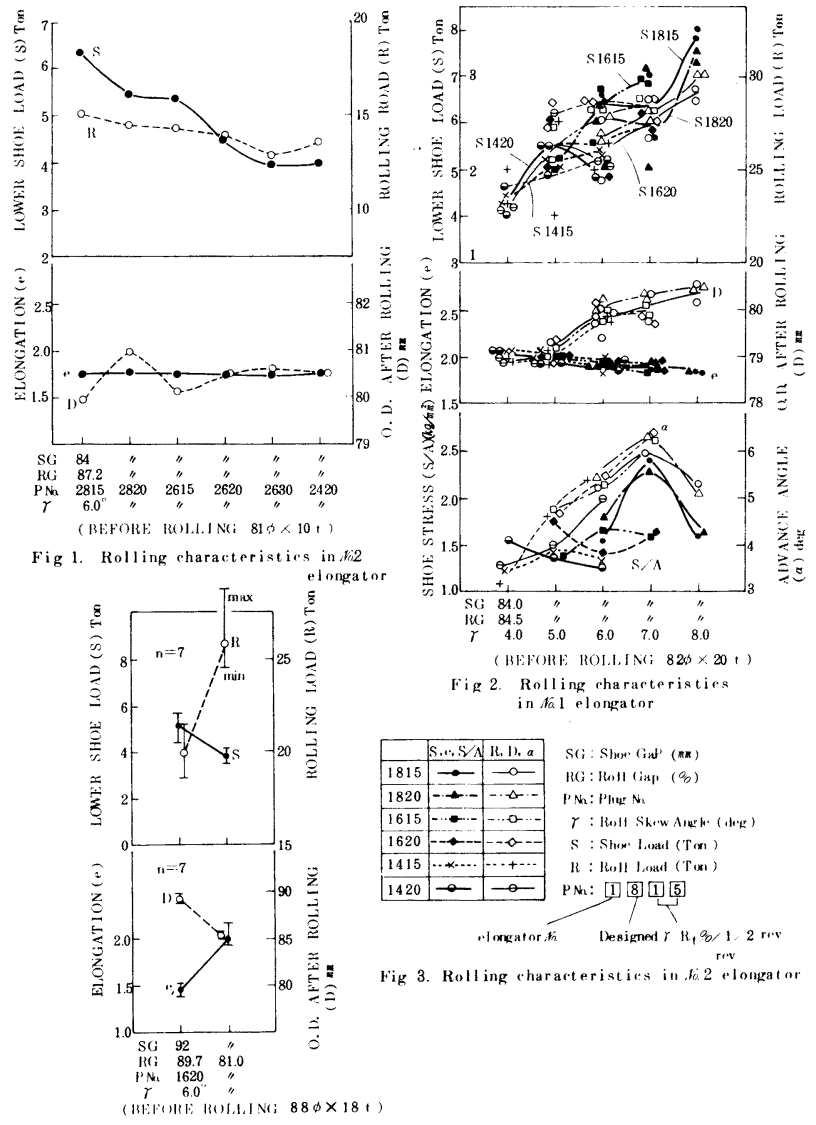


1. 緒言：マンネスマンピアサ, エロンゲータ等の傾斜ロール圧延機では, 後端部圧延時に尻割れ, フレアリ ングが発生しやすく, この工程のほか次工程の作業性も阻害している。本報では熱間モデルミルを用いて後端部の 変形解析を行ない, トラブル防止対策を提案した。

2. 第 1 回実験：80mm 中鋼片をPPMで穿孔したのちＮ.1 エロンゲータ（1EL），N.2 エロンゲータ（2EL)圧延 を行なった。供試材の形状は写真 1 中に示した。PPMでは故意に一方向に偏肉を生じさせ, 偏肉率 $25 \sim 30 \%$ 管 を選別採取し，素管偏肉方向を基準として解析した。主な結果を次に示す。

(1) 压延後の管端おうとつ方向と素管偏肉方向は相関ありとは云 学ない。

（2） 素管 $\mathrm{t}_{\text {max }}, \mathrm{t}_{\min }$ 分布は傾斜圧延特有の波状分布に変る（Fig 1)。

(3) 管端おうとつはそれぞれ $t_{\min }, t_{\max }$ 分布の延長上に多い (Fig 1)。

（4） 2EL ではPPMでのボトム残長が長いものほどおうとつを生じ, マンネスマンピアサと同条件の $\mathrm{L}_{\mathrm{B}}=80 \mathrm{~mm}$ は最も悪い(Photo 1 )。

（5）薄肉圧延ほど, 伸び率大ほど後端形状は悪い。

3. 第 2 回実験：第 1 回の再実験のほか旋削した $0 \%, 40 \%$ 偏肉管の

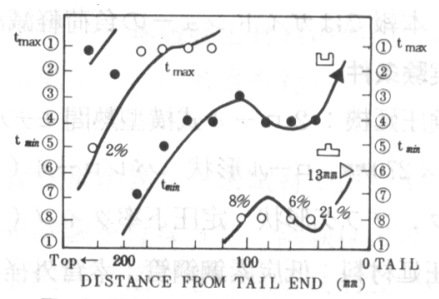

FIg. 1 Thickness distribution after $1 \mathrm{EL}$

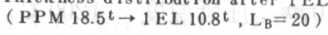
外面に格子目を刻んで圧延した。第 1 回実験結果は再現でき, 格子目 の解析により新たに次の結果を得た。

（6）外面格子間隔は偏肉矯正に対応する規則的な変化はない(Fig 2)。

（7）貫通管圧延時には後端 $40 m m\left(\frac{1}{2} \mathrm{D}\right)$ 以内で元厚肉部が周, 長さ方 向に伸びる傾向が認められ，隣接する薄肉部で破れやすい。

4. 第 3 回実験 : 第 1 回, 第 2 回の再現実験のほか, エレクトロンビー ムを用いた鋼の変形解析法*によりメタルフローを解析した。第 1 回, 第 2 回の実験結果は再現でき, 後端付近のメタルフローとそのメカニズ

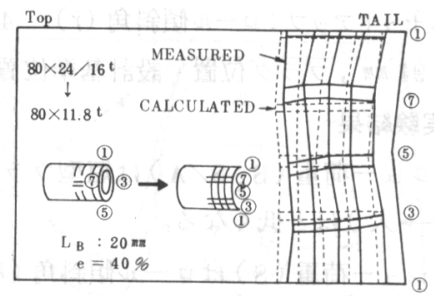
Fig 2 Lattice deformation after $1 \mathrm{EL}$ ムが解明できた。新たに次の結果を得た。

（8）ガイドシュ一間隔を大きくすると後端形状は悪化する。

(9) 短形 (高圧下率) プラグの方が後端形状はやや良い。

（10） $2 E L$ 前または後の後端偏肉が悪いと後端形状は悪い。

（11）内面近傍で周方向の厚肉 $\rightarrow$ 薄肉の流れにより均肉化 する。

（12）ボトム残長 $\left(\mathrm{L}_{\mathrm{B}}\right)$ が長いはざ周方向剪断変形が大きい

(13) 後端は周方向剪断変形が小さく, 偏肉が残りやすい。

（14）マンネスマンピアサに近づくはど周方向剪断変形は大 きく, 後端偏肉は大きく, 尻割れを生じやすい。

(15) マンネスマンピアサでのもみ割れは尻割れの起点にな りやすい。

5. 結＼cjkstart言：傾斜ロール圧延機での後端形状を改善するに は 1 台当りの伸び率を軽減させるとと, $2 \mathrm{EL}$ で薄肉に圧延 する前に後端まで偏肉を矯正しておくことが重要である。 PPM t追加するととによりこれらの対策は実施できる。

* 吉原, 西田, 神田, 海老名,

鉄と鋼 $66(1980), 4, p 322$

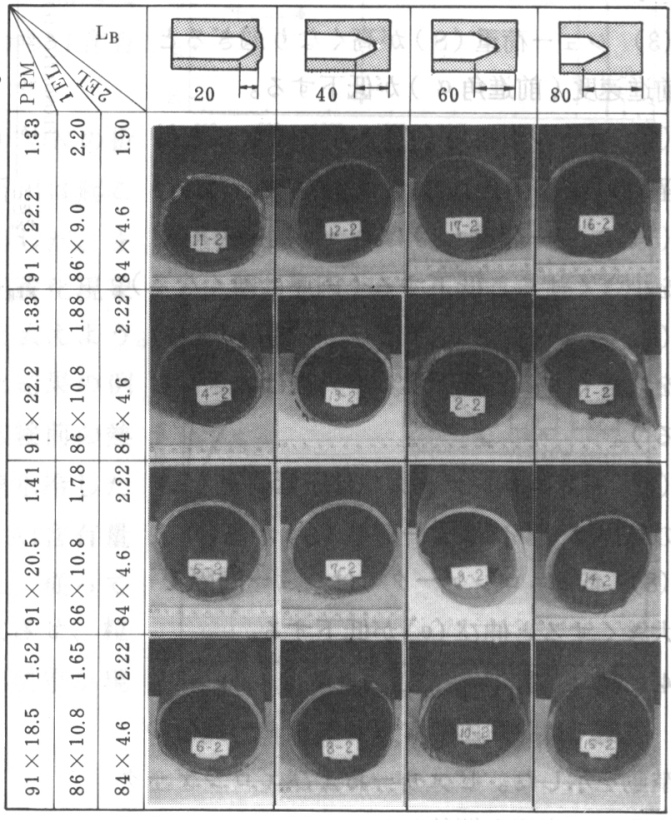

Photo 1. Tail end after No.2 el ongator 


\section{（398） エロンゲータ圧延における偏肉矯正のメカニズム}

' $80-\mathrm{S} 999$

傾斜ロール圧延機の変形解析について( 第 2 報)

新日鐵 八幡 ○吉原征四郎, 合田照夫

1. 鍺言：シームレス鋼管は丸または角断面ブル 一ムを穿孔したのち複数の圧延機で引続き圧延して目標 寸法に仕上げる。穿孔時には肉厚が不均一となり偏肉 を生ずる。次工程にェロンゲータを配置して矯正せん とするが, 場合によってはかえって悪化させた。従来 偏肉矯正メカニズムは圧延による形状の変化によると 考えられてきたが，乙れでは説明できない幾つかの現 象を観測している。筆者らは先に紹介したエレクトロ ンビームを用いた鋼の変形解析法 メタルフローを解析するととにより偏肉矯正メカニズ ムを明らかにした。

2. 偏肉挙動とそのメカニズム : 次表に要約して示した。

\begin{tabular}{|c|c|c|c|}
\hline 現 & 因 & メカニズム & 効果 \\
\hline \multirow{3}{*}{$\begin{array}{r}\text { 1.プラグなし王 } \\
\text { 延部で優先 } \\
\text { 増肉(Photo } \\
\text { 1, Fig. 1) }\end{array}$} & $\begin{array}{l}\text { A 内面近傍で厚肉 } \\
\text { 部から溥肉部へ } \\
\text { 流入 ( Fig. 2) }\end{array}$ & $\begin{array}{l}\text { a 薄肉部内面が最初に } \\
\text { 降伏し圧縮力により } \\
\text { 距離が短縮 (Fig. 2) }\end{array}$ & 大 \\
\hline & $\begin{array}{l}\text { B 内面に対し外面 } \\
\text { は回転方向に進 } \\
\text { 角, 厚肉部が進 } \\
\text { 角大 }\end{array}$ & 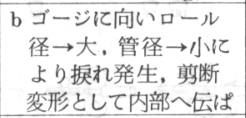 & 小 \\
\hline & $\begin{array}{c}\mathrm{C} \text { 薄肉部は厚肉部 } \\
\text { より压縮応力が大 }\end{array}$ & $\begin{array}{l}\mathrm{c} \text { シュー方向に薄肉部 } \\
\text { が対向する時, 薄肉 } \\
\text { 部が降伏し増肉 }\end{array}$ & 小 \\
\hline $\begin{array}{l}\text { 2. プラグなし } \\
\text { 圧延部で厚 } \\
\text { 肉部は場合 } \\
\text { により減肉 }\end{array}$ & $\begin{array}{l}\mathrm{D} \text { 厚肉部内面近傍 } \\
\text { はロール接触位 } \\
\text { 置で減肉 }\end{array}$ & $\begin{array}{c}\mathrm{d} \text { ロールによる扁平効 } \\
\text { 果によりロール接触 } \\
\text { 位置内面に引張力が } \\
\text { 発生し, 厚肉部内面 } \\
\text { が降伏し伸びやすい }\end{array}$ & 小 \\
\hline \multirow[t]{2}{*}{$\begin{array}{l}\text { 3.プラグは最 } \\
\text { 初に厚肉部 } \\
\text { を压延 }\end{array}$} & $\begin{array}{l}\mathrm{E} \text { 幾何学的にプラ } \\
\text { グは最初に厚肉 } \\
\text { 部に当る }\end{array}$ & $\begin{array}{l}\text { e プラグとロール間で } \\
\text { 圧延 }\end{array}$ & 中 \\
\hline & $\begin{array}{c}\mathbf{F} \text { 厚肉部はプラグ } \\
\text { により薄肉部へ } \\
\text { 押し流される }\end{array}$ & $\begin{array}{c}\mathrm{f} \text { プラグ前部は管内周 } \\
\text { 速より小さく、内面 } \\
\text { を薄肉側へ押し流す }\end{array}$ & 中 \\
\hline $\begin{array}{r}\text { 4.厚肉 } \rightarrow \text { 薄肉 } \\
\text { 移行部で圧 } \\
\text { 延前に増肉 }\end{array}$ & GFに同じ & $\begin{array}{l}\text { g f 亿同じ、および厚 } \\
\text { 肉部は圧下量が大き } \\
\text { く後進が大 }\end{array}$ & 小 \\
\hline $\begin{array}{l}\text { 5.薄肉部压延 } \\
\text { 後增肉大 }\end{array}$ & $\begin{array}{l}\mathrm{H} \text { Hューによる後 } \\
\text { 方圧縮応力が溥 } \\
\text { 肉部で大 }\end{array}$ & $\mathrm{h}$ ガイドシューの抵抗 & 小 \\
\hline
\end{tabular}

3. 結言 : エロンゲータ圧延における偏肉矯正のメ カニズムは主として内面近傍の周方向のメタルフローに よって説明できる。最も効果のある偏肉矯正法はロール 間隔を小さくするととと, ロール, プラグおよばガイドシュー により構成されるパスディザインを適正化するととである。エロンゲータ 在2台連ねることにより偏肉を低いレベルに安定させるととができる。 *吉原, 西田, 神田, 海老名, 鉄と鋼 66(1980), 4, P 322
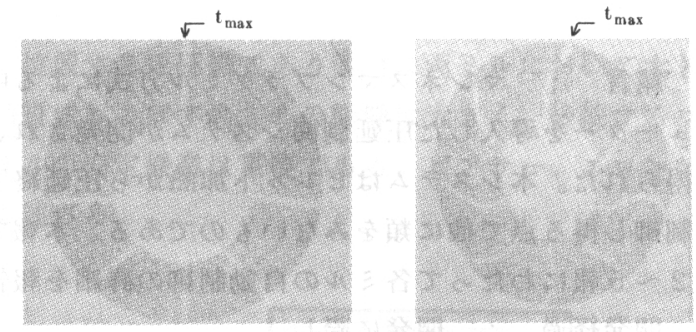

Before rolling $80 \times 22 / 18 m m(e=20 \%)$ Just before plug rolling Photo 1. Sulfur print of a pipe treated with EB.
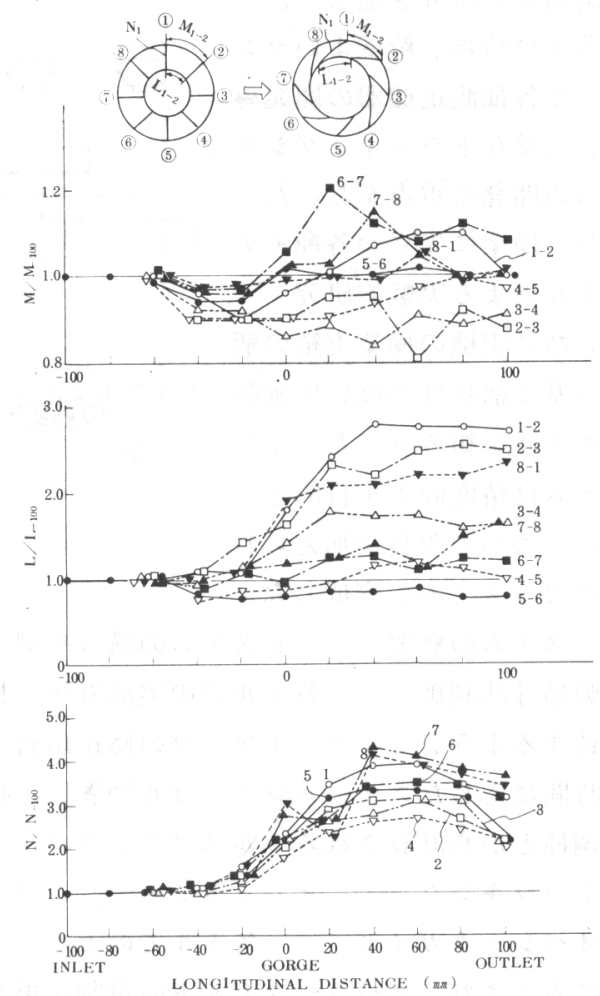

Fig. 1. Variation of EB marks in elongator

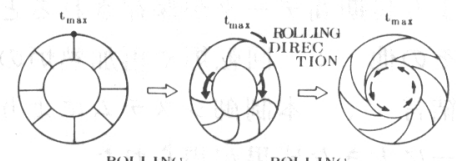

ROLLING ROLLING

Fig. 2. Metal flow in elongator 
' $80-\mathrm{S} 1000$

\section{（399）中径継目無鎆管工場の圧延制御システムの概要}

（継目無鋼管の圧延自動制御に関する研究－Ｉ）

川崎製鉄 知多製造所 ○田口芳男 野沢健吾 上杉 斉

船生 豊 松岡逸雄

技術研究所汇島涁夫

1. 緒言 ； マンネスマンプラグミル方式による中径継目無鋼管工場の稼動に際し、プロセスコンピ ニーターを導入した压延制御システムが開発され、順調な立ち上がりと安定した操業に大きな成果が 得られた。本システムはビレット加熱から压延終了までのすべての压延機および加熱炕とを自動的に 制御し得る点で他に類をみないものである。本報ではシステムの概要とその開発経過について述べ、 2 〜 報にわたって各ミルの自動制御の詳細を報告する。

2. 開発経過 ; 開発に際し、 ハードゥェアとソフトウェア の両面から研究を進めた。 前者では特に、精度よいセン サーや各種測定機器の開発導 入，完壁なトラッキングシス テムの開発に重点をおいた。 また、操業に先立つ各種モデ ルミルによる実験的研究 ${ }^{(1)(5),}$ ならびに実機の操業実績の解 析を基に信頼性の高い压延制 御モデルを組み立てた。本シ ステムは精度向上を目的とし たいくつかの改良が加えられ

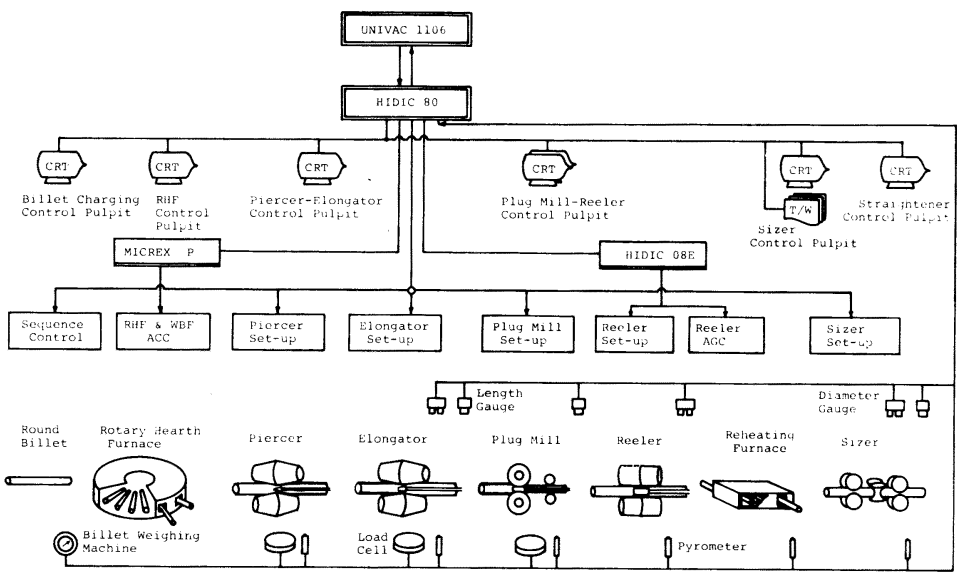

図 1 制御システムの構成 高度なシステムが完成した。

3. システムの概要 ； システムの構成を図1亿示すが、以下の様な制御機能を有している。

(1)製品寸法制御 ； 各ミルでの実測外径，長さおよびこれらより計算される平均肉厚が目標值に一 致するよう、ミルセットアップの修正が管 1 本ごとに行なわれる。この際、素材重量, 加熱焒在炉 時間に応じたスケールロスのばらつき, 工具類の摩耗, 熱膨張による工具位置の変動, 圧延温度と 鋼種とから計算されるミルスプリングバック量などの補正も同時に行なわれる。

(2)トラッキング ； ビレットチャージングテーブルから矯正機出側まで行なわれている。

(3)オペレータガイド ; 各ミルでのセットアップ值, 目標寸法, 実測寸法などの各種情報が C R T に表示され、オペレータガイドの役割を果している。

(4)データロギング ； 管 1 本ごとに約 400 の圧延情報をロギングし、上位計算機とのリンヶージに より長期間データが保存されると同特に、データ解析が容易に行なわれ品質管理に役立っている。 (5)その他；回転炬や再加熱炬の最適燃焼制御，压延工具類の履歴管理が行なわれている。

4. 結言 ; 本制御システムにより、製品寸法精度, 歩止りおよび生産性が向上し、かつ、省エネル ギーに大きな成果が得られた。

参考文献 (1) (2)佐山他；鉄之鋼 64 (1978), 11, S688 S689, (3)中川他； ibid 64 (1978), 11, S690 (4) 冨樫他； ibid $65(1979) ， 4, S 256 \quad$ ，(5)冨樫他； ibid 65(1979)，11，S776 


\section{（400）ピアサー、エロンゲーターの压延自動制御}

$621.774 .31: 681.3$

' $80-\mathrm{S} 1001$

\section{（継目無鋼管の圧延自動制御に関する研究 - II )}

川崎製鉄技術研究所○今江敏夫, 冨整房夫, 佐山泰弘 知多製造所 船生 豊, 相山茂樹, 小林武雄

1. 緒言 ; ピアサー, エロンゲーターは最上流に位置する压延機であり素材は両ミルにおいて大き な塑性変形をうける。従って最終製品の基本的な品質におよぼす両ミルの影響は大きく、後続するプ ラグミルに安定した半製品を供給する意味でも両ミルの安定操業は重要である。ピアサー, エロンゲ 一ターの初期設定ならびに学習制御の概要について述べる。

2. 自動制御方式 ; . 制御モデルは初期設定と学 習制御の機能を有しており、初期設定值は上位計 算機でロット毎に、学習制御は下位計算機により 1 本毎に演算出力される。自動制御方式を図 1 亿 示す。初期設定值は過去の操業実績值の中から最 適值を数式モデル化したものであり、選択すべき 最適プラグ径と、それに対する最適ロール間隔( E )、プラグ先進量 ( L ) およびガイドシュ一間 隔 ( H ) が決定される。ピアサーにおいてはての 初期設定值で実用上十分な寸法精度が得られる。 エロンゲーターにおいてはさらに学習制御を行う。 学習制御では精度のよい外径計および長さ計を設 置して前回压延材の実績值を次材圧下設定にフィ 一ドバックさせる方式を採用している。さらに寸

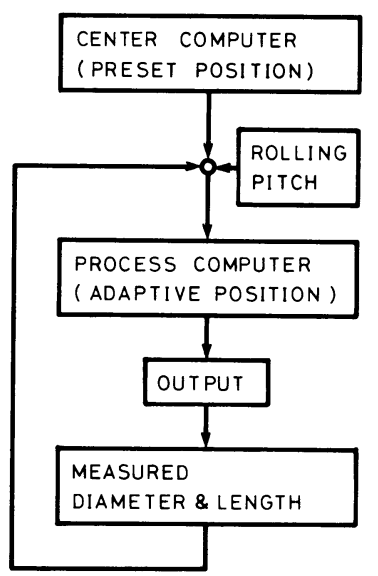

図 1 自動制御方式 法精度を向上させるためには工具の熱膨張量が無 視できない要因となる。本制御モデルにおいては 1 本毎に压延ピッチを実測し工具熱膨張量を補正 して压下設定值を算出している。基礎式を以下に 示す。

$$
\begin{aligned}
& \mathrm{t}=\left(\mathrm{E}^{\prime}-\mathrm{Dp}\right) / 2+\Delta \mathrm{t} \\
& \Delta \mathrm{D}=\boldsymbol{\alpha} \Delta \mathrm{H}
\end{aligned}
$$

ここに

$$
\begin{array}{lll}
\mathrm{t}, \Delta \mathrm{t} ; & \text { 肉厚, 肉厚補正項 } \\
\mathrm{E}^{\prime}, \mathrm{Dp} ; & \text { 出側ロール間隔, プラグ径 } \\
\Delta \mathrm{D}, \Delta \mathrm{H} ; & \text { 外径, シュー一間隔変化量 } \\
\alpha . & ; & \text { 係数 }
\end{array}
$$

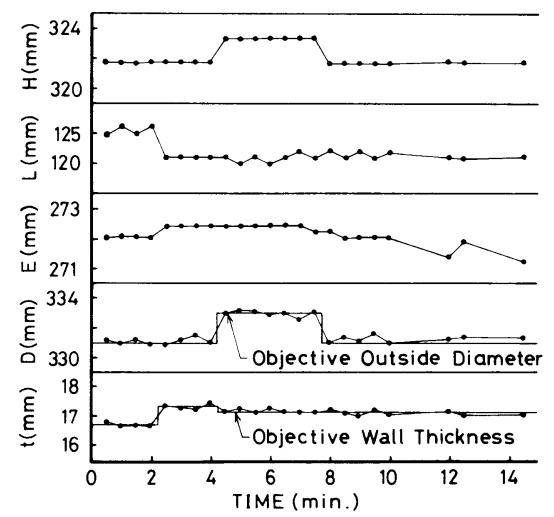

困 2 自動制御压延の実例

3. 結果；図 2 に自動制御厈延の実例を示す。ロット替わりおよび圧延ピッチの変動に対しても、 自動的に目標通りの寸法が得られ寸法精度の安定した半䳤品を後続のミルに供給するてとができた。 